\title{
What Motivates an Oligarchic Elite to Democratize? EVIDENCE FROM THE RoLl CAll Vote ON THE Great Reform ACt OF 1832*
}

\author{
TOKE S. AIDT AND RAPHAËL FRANCK
}

* Toke S. Aidt is Reader in Economics, Faculty of Economics, Austin Robinson Building, Sidgwick Avenue, CB39DD Cambridge, UK. Email: tsa23@econ.cam.ac.uk; and CESifo, Munich, Germany.

Raphaël Franck is Senior Lecturer, Department of Economics, Hebrew University of Jerusalem, 91905 Jerusalem, Israel. Email: Raphael.Franck@mail.huji.ac.il.

We thank Ann Carlos and Dan Bogart (the editors), several anonymous referees, Ekaterina Borisova and Roger Congleton as well as participants at various seminars for helpful comments. Raphaël Franck gratefully acknowledges financial support from the Adar Foundation of the Economics Department at Bar Ilan University. Raphaël Franck wrote part of this paper as Marie Curie Fellow at the Department of Economics at Brown University under funding from the People Programme (Marie Curie Actions) of the European Union's Seventh Framework Programme (FP 2007-2013) under REA grant agreement PIOF-GA-2012-327760 (TCDOFT). We are also grateful to the Cambridge Group for the History of Population and Social Structure and the ESRC (Grant RES-000-23-1579) for helping us with shape files for the maps of the ancient counties and parishes. The research was supported by the British Academy (grant JHAG097). Any remaining errors are our own. 
What Motivates an Oligarchic Elite to Democratize? EvidenCE FROM THE Roll

\title{
CALl Vote on the Great Reform ACt OF 1832
}

\begin{abstract}
.
The Great Reform Act of 1832 was a watershed for democracy in Great Britain. We study the vote on 22 March 1831 in the House of Commons to test competing theories of democratization. Peaceful agitation and mass-support for reform played an important role. Political expedience also motivated some MPs to support reform, especially if they were elected in constituencies located in counties that would gain seats. Violent unrest in urban but not in rural areas had some influence on the MPs. Counterfactual scenarios suggest the bill would not have obtained a majority without these factors.
\end{abstract}


The Great Reform Act of 1832 was a watershed in the development of democratic institutions in Great Britain and set in motion important economic and social reforms, including the reform of the Poor Laws, a new system of local government, the repeal of the Corn Laws and the factory acts regulation of working hours. ${ }^{1}$ In this article, we study what motivated the oligarchic elite to endorse democratic reform. We take advantage of the fact that the reform bill was debated and voted on in the British House of Commons by the Members of Parliament (henceforth MPs) elected under the rules of the Unreformed Parliament, as the British political system between the 1688 Glorious Revolution and 1832 is usually called. Specifically, we argue that the critical roll call vote that took place on 22 March 1831, when the draft bill had a second reading and was passed with a one-vote majority, is critical for understanding democratization in an oligarchy. ${ }^{2}$ Arguably, a few additional votes against the bill could have stopped, or at least delayed, parliamentary reform and thus the economic reforms that followed, and it is therefore important, for historical reasons, to understand why this did not happen.

From a theoretical perspective, the vote record of the MPs enables us to evaluate the relative importance of three prominent theories which shape the debate related to the extension of the voting franchise during the $19^{\text {th }}$ and early $20^{\text {th }}$ century in Western Europe

\footnotetext{
${ }^{1}$ The link between the 1832 Reform Act and economic reform is particularly clear in the case of the repeal of the Corn Laws in 1846 where many Tory MPs, who opposed the repeal, were concerned that the reform bill had empowered the free trade sectoral interest of urban manufacturers (Aydelotte 1967; Kindleberger 1975; Schonhardt-Bailey 2006, p. 40). Other examples of economic policies adopted in the wake of the Great Reform Act that favored the existing oligarchy include the reforms of factories in 1833, of poor laws in 1834 and of municipal corporations in 1835 (for example, Blaug, 1963; Nardinelli, 1980, 1990; Boyer, 1993). Mokyr (2009) provides a general overview of the period.

2 The actual vote took place on 23 March 1831, at 3 am in the morning (Brock 1973, p. 176). We follow the convention to date the vote to 22 March 1831, when the last day of debate started.
} 
(for example, Rueschemeyer et al. 1992, Collier 1999, Ziblatt 2006). The first is that democratization was the result of a "threat of revolution". According to this view, the oligarchic elite that had a monopoly on political power saw little advantage in sharing this power with others. They only unwillingly conceded franchise extensions because they feared a revolution that would fundamentally overthrow the existing economic and political order; in other words, democratic reform was used to pre-empt a revolution. This theory has a long pedigree. It was George Macaulay Trevelyan (1920)'s interpretation of the Great Reform Act of 1832 and the theoretical work by Daron Acemoglu and James A. Robinson (2000, 2008) and Carles Boix (2003) has given it new prominence. ${ }^{3}$

The second theory sees democratization as demand-driven and politicians as influenced by peaceful agitation, lobbying and mass-mobilization in support of reform. Ben Ansell and David Samuels (2010, 2014), for example, stress that the new economic interests created by the industrial revolution in the $19^{\text {th }}$ century demanded protection from the state in the form of a broader suffrage. Valerie J. Bunce and Sharon L. Wolchik (2006) and Erica Chenoweth and Maria J. Stephan $(2009,2011)$ argue that non-violent mobilization was instrumental in bringing about democratization in several countries in South Asia, Eastern Europe, and Sub-Saharan Africa in the 1990s. The theoretical literature on informational lobbying (e.g., Grossman and Helpman 2001) shows how agitation and costly massmobilization can convey credible information about the intensity with which special-interest groups care about an issue. This can, in turn, convince politicians who are unsure about the right course of action to change their position. In short, expressions of public opinion can sway politicians leading to democratization.

\footnotetext{
${ }^{3}$ See also Falkinger (1999), Conley and Temimi (2001) and Dorsch and Maarek (2015).
} 
The third theory is that democratization was the result of political expedience or selfinterest unrelated to any fear of revolution or agitation. Roger D. Congleton (2007, 2011) emphasizes Pareto-improving constitutional bargaining between King and Parliament; Alessandro Lizzeri and Nicola Persico (2004) emphasize that suffrage reform was used strategically by the elite to change the policy mix from particularistic spending to spending on public goods; Toke S. Aidt, Martin Daunton, and Jayasri Dutta (2010) view suffrage reform as a Pareto-improving exchange of tax revenue for political influence; Humberto Llavador and Robert J. Oxoby (2005) stress that co-opting some parts of the working class was beneficial to the oligarchic elite; and Gertrude Himmelfarb (1966) emphasizes party political advantage. The key idea underlying all these theories, however, is that it is in the self-interest of some part of the existing oligarchic elite to change the franchise rules.

The Great Reform Act is well-suited to evaluate the relative extent to which (1) threats of revolution, (2) expressions of public opinion, or (3) political expedience induced the members of the ruling oligarchy to democratize. First, the fundamental difficulty with any test of the threat of revolution theory is that the threat is, by its very nature, not directly observed. We get around this difficulty by directly quantifying the degree of actual violent unrest preceding the second reading of the reform bill and use that as a proxy for the perceived threat of revolution (see, Przeworski (2009), Aidt and Jensen (2014), Aidt and Franck (2015) for a similar approach). ${ }^{4}$ Between Prime Minister Charles Grey’s announcement of parliamentary reform in November 1830 and the Royal assent on 7 June 1832, England experienced high levels of social unrest which included a major violent rural

\footnotetext{
${ }^{4}$ Another way around the difficulty is to use the stock or bond market as a barometer for how threatening investors perceive the situation to be and to use event study techniques to study market participants' reactions to the passage of particular reforms or to events in the run-up to a reform. (for example, Turner and Zhan 2012; Lehmann et al. 2014; Dasgupta and Ziblatt, 2015; Seghezza and Morelli, In Press).
} 
uprising in the hinterland of London (known as the Swing riots) and violent confrontations between workers and police in many of the fast expanding industrial cities in the North of England and in London (Tilly, 1995). Geographical dispersion in the intensity of violent unrest enables us to directly evaluate the effect of fears of revolution by comparing the votes of MPs elected in areas with high levels of violent unrest to those elected in areas with low levels. Second, during the same period, England not only experienced a rise in violent unrest, it also experienced a surge in public demand for democratic reform from civic society and special interest groups such as the Birmingham Political Union (Horn and Tilly 1988, Brock 1973). This allows us to quantify the effect of peaceful mass mobilization through public meetings and demonstrations related to parliamentary reform in the areas where the MPs were elected on their vote on the bill. We also explore the fact that thousands of petitions related to the reform were presented to the House of Commons to measure lobbying for and against the reform and in that way quantify the role of lobbying on the vote of the MPs elected in the constituencies which petitioned. Third, we can directly evaluate the extent of self-interested voting because the bill's two main features - redistribution of seats and reform of the suffrage rules - allow us, when combined with detailed bibliographic information, to predict whether a MP would personally benefit or lose from the bill. In particular, the appendices to the draft bill listed the constituencies to be disenfranchised (in other words, to lose the right to elect MPs) and the places, mainly the expanding industry cities in the Midlands and in the North of England, that were to gain representation. Moreover, the bill changed the voting franchise in the counties in favor of the landowners. These features allow 
us to measure the geography of expected gains and losses, and in that way, test for political expedience in the voting behavior of the MPs. ${ }^{5}$

The results of our econometric analysis show that conditional on party affiliation, the MPs' votes were influenced by violent social unrest in urban (but not rural) areas, by peaceful agitation and expressions of mass-support for reform and were also motivated by political expedience. A "horse race" between the competing theories suggests that petitions and public agitation related to the reform were more important than fears of revolution created by exposure to violent urban unrest. Since the bill passed with a one-vote majority, two additional nays were all that was needed to block the bill. Our estimates enable us to evaluate counterfactual experiments to see if violent urban unrest, reform agitation and political expedience were substantive enough to switch at least two votes. We find that this was the case.

Our paper is related to a growing literature that demonstrates the value of moving away from comparative analysis of the causes of democratization at the macroeconomic level (such as Gundlach and Paldam 2009; Dincecco et al. 2011; Aidt and Jensen 2017) towards detailed quantitative analysis of particular episodes of democratization at the microeconomic level (such as Copaccia and Ziblatt 2010; Berlinski and Dewan 2011). Within this new literature, our analysis is most directly related to Toke S. Aidt and Raphaël Franck (2013, 2015) and Aditya Dasgupta and Daniel Ziblatt (2015) who test the threat of revolution theory in relation to the Great Reform Act of 1832. Aidt and Franck (2013) explore that a sequence of reform-related roll call votes, including the critical second reading on 22 March, took place in the House of Commons in 1831. Since the intensity of violent unrest also varied across this

\footnotetext{
${ }^{5}$ Ziblatt (2008) pioneered this approach in his study of the (failed) reform of the voting system in Prussia in 1912. It has also been adopted to study how sectorial interests affect support and opposition to trade policy (Schonhardt-Bailey 2006) and ballot reform (Mares 2015).
} 
period, it is possible to evaluate the effect of fears of revolution on the voting behaviour of the MPs. They find suggestive evidence that the threat of revolution affected the pro-reform Whigs but had no effect on the opposition coming from the Tory party. Aidt and Franck (2015) study the general election in April-June 1831, exploiting the political geography of the Unreformed Parliament to link the election result to the degree of social violence observed in the immediate vicinity of each constituency during the Captain Swing riots in the winter of 1830-31. They find, consistent with the threat of revolution theory, that exposure to local riots had a large causal effect on the likelihood that a pro-reform Whig MP was elected. Dasgupta and Ziblatt (2015) study the reaction of the British sovereign bond market to the social unrest that preceded the 1832 reform and show that the yield increased in the run-up to the reform but fell back immediately after it was passed. They interpret this as evidence in favour of the threat of revolution theory. Our study goes beyond this previous research by systematically evaluating three theories of democratization (including the threat of revolution theory) in relation to the critical second reading of the reform bill. Substantively, we add to the literature by showing that reform agitation and political expedience were important drivers of reform, and that the threat of revolution played a lesser role in securing a majority in favor of reform in March 1831.

\section{VOTING ON THE GREAT REFORM ACT: BACKGROUND AND HYPOTHESES}

\section{Parliamentary reform in Britain}

Despite the relocation of economic activity and internal migration, the new economic centers in the North and in the Midlands had no representation in 1830, many constituencies established in the Middles Ages were largely depopulated, and a very small proportion of the 
population had the right to vote (Brock 1973, Ch. 1). ${ }^{6}$ Indeed, the rules for elections to the House of Commons had not fundamentally changed in nearly 200 years.

The 489 English Members of Parliament (MPs) were elected to the Unreformed House of Commons from 244 constituencies (Fischer 2009). The 41 English counties returned two to four MPs on a property-value qualified franchise while the borough constituencies (which were predominantly located in rural market towns) could, typically, return two MPs as did the graduates of the universities in Cambridge and Oxford. In the socalled "rotten" boroughs, patrons, who were typically large local landowners, nominated the MPs. $^{7}$

The MPs received no salary and election was subject to a high property qualification. This prevented individuals from the lower classes from running and the House of Commons was dominated by men of substantial wealth, mostly landowners or their sons, merchants and industrialists. In addition to their main place of residence, which for the landed gentry would be a country estate and for merchants and industrialists would be in one of the larger provincial towns in the area where they were elected, most MPs had a residence in London. There was no requirement that a MP lived in the constituency in which he was elected and most did not, especially not if elected in a small rural (borough) constituency.

\footnotetext{
${ }^{6}$ Cannon (1973, appendix 4) estimates that approximately 344,250 adult males could vote in England out of a total population of $12,976,329$.

${ }^{7}$ For instance, Dunwich was a prosperous port and market town when it was granted the privilege of returning two MPs in 1298. However, because of coastal erosion, all but one of the eight medieval parishes of Dunwich were under water by the end of the $18^{\text {th }}$ century. Fisher (2009) estimates that in 1831, there were only 232 inhabitants left and about 33 freemen of the borough could vote. However, in the larger constituencies, elections were more competitive and the electors could exhibit some political independence (O'Gorman 1989) although electoral corruption was rife in many places.
} 
The MPs formed political groups in the House of Commons. The Whig and Tory parties made up the dominant factions, with a few Radical MPs elected in London and the larger provincial constituencies (in 1830). However, these factions were not political parties in the modern sense. They were factions with parliamentary leaders, core followers and regular supporters. They were sufficiently organized to hold meetings as well as to organize their own patronage networks and party finance but crucially, party discipline remained imperfect, even on seemingly core issues such as Catholic emancipation or parliamentary reform (Machin, 1964; Mitchell, 1967, Ch. 1; Hill 1996; Jupp 1998). This meant that the MPs had a large degree of freedom to determine how they would vote on particular bills. ${ }^{8}$

Some attempts at parliamentary reform had been made from the 1780s onwards, notably in the 1820 s by John Russell, Charles Grey and other leading Whig politicians, to address the uneven geographical distribution of seats, electoral corruption, and the limited voting franchise, but without success (Cannon 1973, Ch. 7) until the Great Reform Act of 1832. The bill had two main pillars. First, it changed the suffrage rules by standardizing the franchise. All male householders in the borough constituencies who occupied property worth

\footnotetext{
${ }^{8}$ Mitchell (1967, Chap. 1) provides several quotes by contemporaries and politicians who sat in the Unreformed Parliament as to how they defined party. Charles Grey's definition of party is particularly illuminating as an example of how the parliamentary factions differed from modern parties. He viewed party as "the connection of honourable and independent men to support their common principles, which they can do more effectually by united than by divided efforts. Thus supposes a general agreement on great public questions, and occasional concessions on points of minor importance where such become necessary for the general advantage; but none on leading and material principals; the moment there arises a disagreement on these the party is dissolved, on the same honourable ground on which it was first united. It was upon this principle, when very young that I originally connected myself with the whig party, and I was glad to have the advantage of being assisted and directed in my course, whilst I sacrificed nothing of my independent, by those for whose experience, and integrity and talents I had the highest respect" (Grey to S. Whitbread, n.d. [May 1820], cited by Mitchell (1967, p. 7).
} 
$£ 10$ a year were given the vote while voting rights in the county constituencies were extended to copyholders of land and to various groups of tenant farmers (see Evans (2000, Appendix I) for details). Second, the bill redistributed seats from the small "rotten" boroughs to the large and growing industrial cities and to the counties. The immediate consequences of the reform were limited to redistribution of parliamentary seats, to a modest extension of the franchise to "respectable" segments of the middle class, and to the introduction of a uniform set of suffrage rules based on property. However, in the broader historical perspective, it must be viewed as a watershed that set in motion a long process of political and economic reforms (Maehl 1967, p. 1).

The reform process started with the 1830 general election. The Tories, who had been in power since 1807 and who had opposed any attempt at parliamentary reform, could not agree on a new prime minister. This gave the Whigs, led by Charles Grey, an opportunity to form a government and to put the reform question on the agenda. Grey made his intentions clear in the House of Lords in November 1830, a few days after having been appointed prime minister:

\footnotetext{
"The principal of my reform is to prevent the necessity of revolution.... The principle on which I mean to act is neither more nor less than that of reforming to preserve, and not to overthrow" (Hansard HL Deb 22 November 1830, vol. $1, \mathrm{c} 613)$.
}

The bill's journey through the political process was, however, far from smooth and it could have failed at a number of hurdles along the way. Formally, as a piece of legislation sponsored by the government (a public bill), the legislative process started with a member of the government presenting the bill in the House of Commons where it was first read which was usually a matter of routine and rarely required a formal vote (Escott 2009). The bill was then printed to enable the MPs to consider its general principle. The critical junction was the 
vote after the second reading in the House. If the bill obtained a majority of votes after the second reading debate, it went into a committee, for scrutiny clause by clause. For important public bills, such as the reform bill, this took place in a committee of the whole House. The bill with majority-supported amendments would then be returned to the House of Commons for general debate and a third reading, where further amendments could be made, before it was sent to the House of Lords. The Lords might vote for the bill without any modification and ask for royal assent, reject it, or modify it and send it back to the House of Commons.

In Figure 1, we present a timeline of the main events related to the reform bill based on Michael Brock (1973). The first major hurdle was the second reading of the bill in the House of Commons on 22 March 1831 where it was approved in a 3am vote by the slightest of majorities: 302 in favor and 301 against. Prime Minister Grey was keenly aware that a one-vote majority was not sufficient to get the bill through the committee stage and the House of Lords without major concessions and he asked the King to dissolve parliament. The general election in April-June 1831 was the second hurdle and effectively became a referendum on parliamentary reform. Many anti-reform Tories were not returned and the election result gave the pro-reform Whigs the majority they needed to pursue the reform. In particular, in the 513 English and Welsh seats, the number of Whigs and Radicals increased from 220 to 289. In the three subsequent votes in the House of Commons in July, September, and December, the bill was supported by large majorities (Aidt and Franck 2013, Table 3). The third hurdle occurred in September 1831 when the House of Lords rejected the bill and send it back to the House of Commons. After the second reading of a revised bill on 17 December 1831, where some concessions to the Lords were made, a frantic period of lobbying of individual Lords followed until the House of Lords approved the bill by a 9-votemajority in April 1832. Again, this was insufficient to get the bill through the committees, and Grey offered his resignation if the King did not promise to create enough new Lords, if 
needed, to carry the bill. The King eventually made that promise and the bill passed as the Tory opposition did not wish to risk losing their majority in the House of Lords. The bill received royal assent on 7 June 1832 . These hurdles were not only significant but the way each of them was overcome can also provide important insights into the mechanisms of democratization. In this study, we focus on the first hurdle, in other words, the second reading of the bill in the House of Commons, while Aidt and Franck (2015) study the second hurdle, in other words, the election in 1831.

Out of the 658 MPs elected from across the United Kingdom to the House of Commons, only 27 (including 18 from England) were not present for the second reading on 22 March 1831, with a further seven seats unfilled on the day. This was an abnormally large turnout. The net result, after 20 MPs including the four Tellers were paired off and the Speaker of the House followed tradition and abstained, was a one-vote majority (302 vs. 301). Table 1 shows for the English seats the breakdown of the vote for the Tories, Whigs and the four Radical MPs, along with the vote totals for Wales, Scotland and Ireland. The majority of the 489 English MPs and of the 45 Scottish MPs voted against the bill while the majority of the 100 Irish and of the 24 Welsh MPs supported it. The opposition in England came almost exclusively from the Tories while the Radical MPs and the vast majority of the Whigs voted in favor. However, party discipline was imperfect: the 45 MPs who deviated from the party line were critical for the bill's success.

Social tension in 1830-31

In the years that preceded the royal assent of the Great Reform Act, social tension was high in Britain and took many forms. Some of the protest was organized, peaceful and directed at the question of parliamentary reform, but some of it was violent and not, in most cases, directly related to parliamentary reform. Those differences could not have eluded the MPs who read newspapers, communicated with associates in their constituencies and, in 
some cases, had access to Home Office reports. Before laying out our hypotheses in the next sub-section, we provide a typology of protests during the period.

Social unrest and mass protest in Great Britain reached very high levels in the early 1830s (Stevenson 1992; Bohstedt 2010). Charles Tilly (1995, p. 97 and Table 2.2) estimates that at least 91 individuals were killed, more than 2000 arrested and several million individuals were involved in various types of public protest. Some unrest was violent and had to be put down by force. We make a distinction between violent unrest in rural and urban areas. The largest wave of rural violent unrest was the Swing riots that took place between August 1830 and March 1831 when landless agricultural laborers in London's hinterland burned hayricks, smashed threshing machines and demanded higher wages (Hobsbawm and Rudé 1973). Urban violent unrest included instances of violent street confrontations, for example, in Derby in 1830 and in Bristol in 1831, as well as turbulent strikes, e.g., in Barnsley, Bethnal Green, Coventry, Manchester, and Spitalfields in 1829 (Tilly, 1995). Such major events were widely reported in the local and national newspapers, but even what appears in hindsight to be some instance of minor street violence would be known to the MPs. For instance, the Morning Chronicle and the Times of London reported in the 10 November 1830 edition that after a meeting near radical activist Richard Carlisle's ramshackle building (the Blackfriars Rotunda) on 9 November 1830, about 1000-1500 persons confronted a detachment of the police with cries of "Down with the police!", "No Wellington" and "No Peel!". Home Secretary Robert Peel described it in the House of Commons as "some unpleasant collisions between the police and the mob at Temple Bar, and other parts of the Strand" (Mirror of Parliament, 10 November 1830, cited by Tilly (1995, p.314)). Hallmarks of violent unrest during the period were that it, on the one hand, was not (in most cases) related to parliamentary reform but to a variety of special economic and social demands and that it, on the other, helped steer up fears of a revolution. 
However, most of the protest was peaceful expressions of public opinion. Partly due to less blatant government repression of organizations in the late $1820 \mathrm{~s}$, urban political associations, such as the Birmingham Political Union or the National Association for the Protection of the Workers, had become sufficiently organized to mobilize peaceful mass protest (Thompson 1963, Ch. 14). In the lead-up to the roll call vote in March 1831, they organized public meetings in support of the reform which, on occasion, attracted thousands of participants. In other instances, freeholders, parishioners or religious congregations met publicly to express their views on the reform question (Tilly 1995, Table 7.3). These events were announced in the local newspapers and often reported in the London-based national newspapers after the fact. For instance, a large peaceful demonstration in favor of reform was held in London on 12 October 1831. The following day, the Morning Chronicle described it as "about 300,000 inhabitants of the metropolis - chiefly tradespeople and industrial artisans, with the Parochial Officers at their head - walked in procession from their respective parishes to St. James's Palace” (Tilly, 1995, p. 329). Unlike violent unrest, much of the peaceful protest that took place during the period was directly linked to agitation for or against parliamentary reform.

Individuals, groups or organizations could also petition Parliament directly (Jupp 1998). According to the record in the Journals of the House of Commons, more than 3000 petitions related to parliamentary reform were received between November 1830 and June 1832. These petitions were addressed to particular MPs and presented in Parliament. Some of them were signed by thousands of people, such as one received by the MP John Savile Lumley in March 1831 from "2500 most respectable persons” (Hansard HC Deb 22 March 1831, vol. 3, c705) among the freeholders of the county of Nottingham petitioning in favor of the reform. Others represented the view of smaller and more select groups such as the petition from the University of Cambridge against the reform (Hansard HC Deb 22 March 1831, vol. 
3, c706). The petition system allowed organized groups outside the ruling elite to lobby by making their views on the reform question known directly to the MPs.

\subsection{Hypotheses}

The second reading of the Great Reform Act of 1832 provides a unique opportunity for testing three competing theories of democratization within a common framework. The first theory maintains that the autocratic politicians accept democratic reform because they fear a revolution. The Whig school of Victorian historians (e.g., McCarthy 1852; Trevelyan, 1920, 1937, pp. 635-36) emphasized this theory in relation to the Great Reform Act and the threat of revolution is central to Acemoglu and Robinson $(2000,2006)$ 's theory of franchise extension. How threatening the MPs perceived the situation to be was a function of the actual level of violent unrest that came to their attention during the period before the second reading. The MPs would learn about violent unrest in the areas where they were elected through their networks of contacts or through direct observation, and would learn about major events across the country through the national newspapers. To a first approximation, the MPs had access to the same nation-wide information on violence, so the variation is their perception of the threat would primarily come from variation in violent unrest in their "local" area. We can formulate this as the first testable hypothesis:

The Threat of Revolution Hypothesis: MPs who were elected in areas exposed to violent unrest perceived a greater threat of revolution and were more likely to vote in favor of the reform.

The literature on information lobbying and persuasion, e.g., David Austen-Smith (1994), Susanne Lohmann (1995), Gene M. Grossman and Elhanan Helpman (2001), Morten Bennedsen and Sven E. Feldmann (2006), shows how interest groups, by sending costly signals through, for example, large demonstrations or petitions, can convey credible 
information about the intensity with which they care about an issue. ${ }^{9}$ Insofar as the policymakers are uncertain about the merits of a particular reform, they may in that way be influenced by agitation and lobbying and change their mind. This second theory of political reform argues that MPs who were unsure about the value of reform would take a clue from public expressions of reform support or targeted petitions related to the reform question. The key difference between the violent unrest that fuels fears of a revolution and peaceful reform agitation (besides the fact that one is violent and the other is peaceful) is that threat perceptions are governed by observations of violent unrest, whether directly related to the reform question or not, while reform agitation must be related directly to the reform question and thus must be specific. We can thus formulate the second testable hypothesis as

The Public Opinion Hypothesis: MPs who were elected in areas with large-scale public demonstrations of reform support or who were lobbied by reform-supporting constituency interest groups were more likely to vote in favor of the reform.

The third theory maintains that politicians implement major political reforms because they expect to benefit, politically and/or personally, from the new constitutional framework and the new policies that it enables. For the elite or subsets thereof, the prospective gain from reform might be expected changes in post-reform policy (e.g., Lizzeri and Persico 2004; Llavador and Oxoby 2005; Aidt et al. 2010) or in electoral support (e.g., Himmelfarb 1966). However, for individual politicians, the most immediate consideration relates to their chances of keeping their seat under the new rules. We formulate this as the third testable hypothesis:

\footnotetext{
${ }^{9}$ Even "cheap talk" can be influential as long as the sender and receiver have sufficiently overlapping interests (Crawford and Sobel 1982).
} 
The Political Expedience Hypothesis: The MPs followed their own narrow self-interest and voted against (for) the bill if they expected that the proposed allocation of seats or the new voting rules would make is harder (easier) for them to gain election.

\section{DATA}

We draw our data from a variety of primary and secondary sources. The unit of analysis of the main cross-sectional dataset is a parliamentary seat in the House of Commons during the session which lasted from 26 October 1830 to 22 April 1831. Table 2 provides descriptive statistics for the variables used in the main analysis. The full dataset is deposited as Aidt and Franck (2019).

We note that 658 MPs were elected in constituencies in Scotland, Ireland, Wales and England. However, we do not include the Scottish or Irish MPs in the analysis because we do not have data on social unrest and mass mobilization in Scotland and Ireland. In fact, the Great Reform Act did not affect Scotland or Ireland. In the subsequent Scottish Reform Act and Irish Reform Act, however, Scotland obtained eight additional seats and Ireland obtained five. No constituency was disenfranchised in either Scotland or Ireland. As in England and Wales, voter qualifications were standardized and the electorate was expanded (see Evans 2000, Appendix I).

\section{Reform support in the House of Commons}

Our main analysis relates to the 489 English MPs elected in 244 constituencies, ${ }^{10} 466$ of whom were present and voted on 22 March 1831 (9 Tories and 9 Whigs were absent, four English seats were vacant and the speaker, traditionally, abstained). For each of these 466 English MPs, we create the variable yes vote which is equal to one if the MP supported the bill and equal to zero if he voted no (excluding the Speaker). For the sample of the 489

\footnotetext{
${ }^{10}$ Most constituencies returned two MPs, but six had just one and two county constituencies had four seats.
} 
English seats, we also create the variable present which is equal to one if the MP elected to a seat was present in the House of Commons for the vote and zero if not (excluding the four vacant English seats and the Speaker). ${ }^{11}$ In the statistical analysis presented below, we discuss reasons which might explain the absence of the 18 MPs from the second reading of the bill and we also extend the sample with the 24 Welsh MPs, who all attended the vote.

\section{Public Opinion and the Threat of Revolution}

To test the Public Opinion Hypothesis, we need to quantify the MPs' exposure to public opinion, agitation and mass mobilization. We draw on two sources to do this. First, we construct a new constituency-level measure of lobbying from primary sources. As we noted above, it was common for constituency-based lobby groups to send petitions to Parliament either in support of or in opposition to specific bills or issues. These petitions are recorded in the Journals of the House of Commons (1828-1831, vol. 83-86). Based on word searches on the names of the 244 English constituencies, we count the number of petitions related to the reform campaign which originated from each constituency between 1 January 1828 and 22 March $1831 .{ }^{12}$ We code the variable petitions as the difference between the number of petitions for and against parliamentary reform. This measures constituency-level lobbying in favor of reform and enables us to test if the MPs were influenced by the views of the people living in the constituencies in which they were elected. Second, to quantify the broader patterns of agitation and mass mobilization, we draw on the studies of Horn and Tilly (1988)

\footnotetext{
${ }^{11}$ Hansard (1831, vol. 2, pp. 719-826) contains the division list with the complete record of the yes and no votes cast along with the names and constituencies of all MPs. It also lists those who were absent, those who were paired off and those who were Tellers.

${ }^{12}$ During the parliamentary session of 1828,1829 , and 1830 (up to the election held in July to September) only 20 petitions related to parliamentary reform were received, while 400 were received between 14 September 1830, and 22 March 1831. This does not include petitions from unrepresented areas.
} 
and Tilly (1995) who collected information on various forms of "popular protest" in England between 1828 and 1834 from textual analysis of eight London-based periodicals (Annual Register, Gentleman's Magazine, Hansard's Parliamentary Debates, London Chronicle, Mirror of Parliament, Morning Chronicle, The Times and Votes and Proceedings of Parliament). Tilly (1995, p. 63) defines "popular protest" as an event where "10 or more people gather in a publicly accessible place and make claims on other people, including holders of power, claims which if realized would affect the interests of their object". Each event is characterized by several elements describing date and location (usually, the county), an estimate of the number of people involved, who was making the claim, and against whom the claim was directed. We use three types of peaceful protest that happened between 1 January 1828 and 22 March 1831 as proxies for agitation and mass mobilization. Meetings involved organized events where a group of individuals congregated with prior notice, while gatherings were more spontaneous and included street protests of various sorts, including demonstrations, which remained peaceful and non-violent. ${ }^{13}$ While meetings and gatherings enable us to study different types of peaceful protest, some of these meetings and gatherings were not related to the reform question. Our third and main proxy reform agitation uses the classification of Horn and Tilly (1988) to single out the subset of peaceful meetings and gatherings which were related to the reform question. ${ }^{14}$ This provides us with a direct measure of reform agitation.

\footnotetext{
${ }^{13}$ Tilly and Horn (1988) also record the number of delegations. Since there were very few of those (less than 1 percent of all events), we combine them with the meetings.

${ }^{14}$ The quality of the data on public protest is remarkable. They were hand-collected over a 12-year period in the 1970s and 1980s by a research team led by Charles Tilly and coded independently by several researchers (Horn and Tilly, 1988). The very labor-intensive collection method minimizes, if not eliminates altogether, false positives. By definition, the dataset does not include minor events with less than 10 people involved and it does not include events that happened but were not reported in the national newspapers which were the primary
} 
To test the Threat of Revolution hypothesis, we also draw on Horn and Tilly (1988). We single out the events between 1 January 1828 and 22 March 1831 that involved violent unrest which we contend can be used as a proxy for the MPs' perceptions of the threat of revolution. We further sub-divide violent unrest into unrest that took place in rural (violent rural) and urban (violent urban) areas. ${ }^{15}$ Violent unrest in urban areas might have been perceived as being more threatening than unrest in the countryside (Do and Campante 2009).

Over the period from 1 January 1828 to 22 March 1831, Nancy Horn and Charles Tilly (1988) record 2726 protest events. ${ }^{16}$ For many of the events, they give an estimate of the number of individuals involved and for each type of protest, we calculate the number of individuals involved in the events in each county. It is important to take this into account, as a small protest (e.g., a meeting) with 10 individuals involved would have been perceived very

sources. This will tend to underestimate protest. Tilly (1995, p. 398) compares his data from the national newspapers with information extracted from the Lancaster Gazette (a regional newspaper) and concludes that "local and specialized periodicals sometimes reported more events within their own purviews than our national periodicals, but not always and rarely with significantly more detail”. For our purpose, it is appropriate to focus on the main events that made it to the national newspapers as these are the ones that were most likely to catch the attention of the MPs.

${ }^{15}$ Horn and Tilly (1988) do not make a rural-urban distinction. We proxy violent rural protest by the violent events related to the Swing riots and violent urban protest by the residual number of violent events in the county. While all the Swing riots were rural in nature, there might be some element of rural protest in the proxy for violent urban protest, but most would have been urban.

${ }^{16}$ Horn and Tilly (1988) code the information on the number of people involved as a lowest, best and highest estimate to reflect that the sources not always give a precise number. We use the best estimate under the assumption that this is also the number than the MPs at the time would have associated with the protest. For protests where no information is provided, we assume that 10 individuals were at least involved, as otherwise the event would not have been coded in the database. This means that the estimates of the number of people involved is a lower bound. 
differently from a large public demonstration with thousands of participants, such as the reform support meeting in Manchester on 8 March 1831, which according to the Times was attended by 3,000 people. ${ }^{17}$ We consider that each MP was influenced by the scale of the events which occurred in the county where his constituency was located. This is reasonable because counties were natural information hubs for the constituencies and each county had a newspaper which reported local news and those from London (see below, for a discussion of newspaper circulation). ${ }^{18}$ For each type of protest, we thus attribute to each constituency the total number of participants in public protest events which occurred in its county. We define the variable all protest as the aggregate of all types of protest. While we use the number of participants in protests (in 10,000s) in the main analysis, we show in Table A1 in the online appendix that normalizing this number by the total population or by the number of adult males does not affect the results. We also report in Table A2 in the online appendix a replication of the results with the protest variables coded by summing up the number of events by county, irrespective of the number of people involved.

In Table 3, we list the distribution of public protests recorded between 1 January 1828 and 22 March 1831, classified by the type of protest and disaggregated within the six main regions of England and Wales. Most of the protest was peaceful, but 20 percent of the events did involve violence. The average number of participants was 441 . Violent events in rural areas involved fewer individuals than violent events in urban areas. While there were many more meetings than gatherings, gatherings had much larger average participation (2068 compared to 286). Reform supporting meetings and gatherings constituted 18.3 percent of all peaceful protest with participation of 30.2 percent of all individuals involved in these activities. In Figure 2a, we map the geographical distribution of participants in all types of

\footnotetext{
${ }^{17}$ The Times (London, England), Tuesday, 8 March 1831; pg. 4; Issue 14481

${ }^{18}$ See House of Commons (1833a) for a record of local newspapers in 1833.
} 
protest across England by county, and further distinguish between peaceful protest and violent unrest in Figures $2 \mathrm{~b}$ and $2 \mathrm{c} .{ }^{19}$ Peaceful protests took place in the industrial towns in the North and Midlands and in and around London. Violent protest was concentrated in the hinterland of London (mostly rural unrest) and in the North of England (mostly urban unrest).

Figure 3 plots the monthly series of participation in peaceful protest (measured on the right-hand y-axis) and violent unrest (measured on the left-hand y-axis) in England between 1 January 1830 and 1 April 1831. We note that the number of peaceful protests grew in the period leading up to the vote on the Reform Bill. The peak in May 1830 was a large meeting with more than 100,000 participants in Warwickshire and the high level of protest during the summer corresponds to the polling period of the 1830 general election. Violent protests were more concentrated in time. The spike in violence, which occurred in November and December 1830, corresponds to the peak of the violent riots instigated by landless agricultural laborers (the Swing riots).

\section{Political expedience}

To test the Political Expedience Hypothesis, the details of the draft bill enable us to identify prospective winners and losers. Obviously, the MPs elected in the constituencies which were scheduled to be disenfranchised had a personal reason to vote against the bill. We code the indicator variable disenfranchised as equal to one if the constituency that a MP represented was scheduled in the draft bill to lose all seats and zero otherwise.

Patronage played an important role in the Unreformed Parliament. The MPs elected in the borough constituencies controlled by patrons might have been under pressure to oppose reform because the new rules would undermine the old system of patronage even if the

\footnotetext{
${ }^{19}$ Figure A1 in the online appendix reports the geographic distribution of participants in gatherings and meetings.
} 
constituency continued to exist. Based on the contextual information about each constituency provided by J. Holladay Philbin (1965) and the complete record of contested and uncontested elections provided by John A. Cannon (1973), we construct the variable Patron controlled which is coded as one if the constituency was under full or partial control of a local patron or by the Treasury or if no contested election had taken place since 1802, and zero otherwise. Out of the 244 English constituencies, 188 were controlled by patrons. ${ }^{20}$ While the patrons controlled who represented the constituencies, they did not necessarily control how the selected MPs voted on each piece of legislation, but could certainly exert pressure on specific votes, for example, by threatening not to select the MP at the next election, and had a strong incentive to do so with regard to the reform bill. ${ }^{21}$

The reform bill was a threat to the political influence of the landed elite by redistributing seats from the small "rotten" borough constituencies in the countryside to the expanding industrial cities in the North of England and in the Midlands. At the same time, the

\footnotetext{
${ }^{20}$ The number is consistent with that implied by a petition to the House of Commons from the Society of Friends of the People in 1793. It claimed that 157 members were sent to parliament by 84 individuals and that 150 others were returned on the recommendation of 70 powerful individuals (Hammond and Hammond 1911, p 19). This suggests that at least 152 constituencies were controlled by patrons or, as in the case of the corporation franchise, their agents.

${ }^{21}$ For example, the Whig MP William Henry Lytton Earle Bulwer, who represented Wilton in Wiltshire, owed his seat, which was to be disenfranchised, to a Tory patron who most likely put pressure on him not to vote for reform on 22 March 1831 (Fisher 2009). Another example which shows how a MP defied the wish of his patron comes from Cornwall, where James Willoughby Gordon wrote to his patron, who wanted him to oppose the bill, that it was “quite impossible for me as the senior officer upon the King's staff to vote against His Majesty's government under any circumstances whatever." (Fisher 2009). This, nevertheless, appears to be more an exception than the rule. In the words of Charles James Fox speaking in the House of Commons about the issue in 1797 "when a Gentleman ... represents a noble lord or a noble duke, ... he is not considered a man of honour who does not implicitly obey the orders of a single constituent.” (Hammond and Hammond, 1911, p. 19).
} 
draft bill sought to extend the existing voting franchise in the counties to include $£ 10$ copyholders and various types of leaseholders and increased the number of county seats from 80 to 144 . These new voters owed their livelihood to the local landlords and their vote could be influenced by the landed elite. As such, this franchise extension was seen as an attempt to compensate the landed interest for the loss of their influence in the disenfranchised rural boroughs (Brock 1973, p. 222). We code the indicator variable landed interest as one if a MP was elected to a county seat and zero if he was elected to either a borough or to one of the university seats.

As a more general measure of the expected benefit of seat redistribution, we construct the variable net seat gain. It codes the difference between the number of seats allocated to each county and to the borough constituencies located within its borders by the reform and the number of seats in the Unreformed Parliament. ${ }^{22}$ MPs elected in a particular county would have a ready-made network of supporters in that area enabling them to take advantage of the new seats to be established post reform. This variable, therefore, measures the extent to which the MPs supported (opposed) the reform because of seat gains (losses) in "their" county.

\section{Political and economic control variables}

Political parties

\footnotetext{
${ }^{22}$ The source is the appendices to the bill reported in The Statutes of the United Kingdom of Great Britain and Ireland (1832, pp. 154-206) and Philbin (1965). In the results reported in the text below, we use the final seat distribution to calculate the gain/loss in seats. In Table A2, column (10), in the online appendix, we show a specification where we use the proposed reallocation recorded in the appendices of the bill second read on 22 March 1831. It makes almost no difference to the point estimates.
} 
As noted above, "party affiliation" is a strong predictor of how a MP voted. The reform bill was sponsored by the Whig leadership and supported by most Whig MPs (only eight English Whig MPs voted against). It was strongly opposed by the Tory leadership and most backbench Tories, yet 37 English Tory MPs voted for the bill (see Table 1). This reflected the fundamental disagreement about the role of MPs as "trustees", who saw it as their role to act as they thought to be in the national or wider public interest, or "delegates", who should act in accordance to the demands of their constituents or broader special interests (see the discussion in the online appendix) as well as about the role of landownership as the core constitutional principle. We need to control for "party affiliation" so that our tests can isolate the influence of public opinion, political expedience and threat of revolution on the 45 MPs who voted against the "party line" and whose votes were pivotal.

It is not a straightforward task to determine the political affiliation of the MPs. The Tory and Whig groups were relatively loose organizations and some MPs changed their allegiance over their political careers. We evaluated and compared the bibliographical information provided by Charles R. Dod and Robert Phipps Dod (1832), Lewis B. Namier and John Brooke (1964), Henry Stooks Smith (1973), R.G. Thorne (1986), and David Fisher (2009) to construct a complete record of the political affiliations of all the English MPs elected in 1830. We code the indicator variable Whig/Radical as one if a MP was a Whig or a Radical and as zero if he was a Tory to capture the MPs' association with political factions in the Unreformed Parliament.

Newspaper circulation

Newspaper circulation can be used to proxy for the general flow of information. In the 1830s, London was the information hub of England. The MPs had access to the major London newspapers as well as local newspapers from the area from which they were elected, which would often repeat news stories from the London papers (Barker 2000). Many of the 
newspapers were supportive of reform (Jupp 1998) and reported extensively on the proceeding in Parliament. The newspapers were also a major source of information on public protest and the national newspapers often reported on meetings and other reform-related events outside London. ${ }^{23}$ Newspapers were subject to stamp duties on each sheet of paper. ${ }^{24}$ Since the accounts of the Stamp Office report the stamp duties paid by each newspaper, it is possible to estimate newspaper circulation within each county. We code the variable, local newspapers, as the number of newspapers sold per year in each county in 100,000 s (see the online appendix for details).

Economic fundamentals

Based on the 1831 Census of Great Britain, we consider two aspects of the economic environment: employment concentration and population density. First, we measure employment concentration in each constituency with a Herfindahl index, emp. Herfindahl index. It is computed as the sum of the square of the share of individuals in each census registration district working in agriculture, in trade, as professionals and in other occupational categories. ${ }^{25}$ Emp. Herfindahl index varies between zero and one: a value closer to one

\footnotetext{
${ }^{23}$ See, for example, The Times (London, England), Friday, 4 March 1831; pg. 4; Issue 14478; The Times (London, England), Tuesday, 8 March 1831; pg. 4; Issue 14481, or The Times (London, England), Friday, 11 March 1831; pg. 4; Issue 14484.

${ }^{24}$ Stamp duties made newspapers too expensive for ordinary people. In contrast, the MPs had access to all the major London newspapers and could mail copies free of charge to family and patrons in their constituency. The source of this information is two returns to Parliament in 1833 about the number of stamps issued for all London and all English provincial newspapers (House of Commons, 1833a, 1833b). While there may be inaccuracies with respect to the stamp returns of some newspapers, the figures should overall give a fair picture of the total circulation of newspapers in that year.

${ }^{25}$ The occupation categories are those tabulated in the 1831 Census of Great Britain and each constituency is matched to the Census registration district that is the closest geographical unit.
} 
implies that employment is concentrated in fewer sectors. Second, we measure population density as the number of individuals per inhabited house in the constituency, as recorded in 1831 Census of Great Britain. We conjecture that areas with more concentrated employment structures and higher population density could articulate reform support (or opposition) more effectively.

Personal characteristics of the MPs

We account for the possibility that the personal and professional characteristics of the MPs might have influenced their votes. From the bibliographical notices compiled by Fisher (2009), we obtain information on the MPs' age, education and occupation. We record whether a MP attended secondary school and/or university. About $74 \%$ of the MPs attended secondary school while $66 \%$ also attended university. At the time, a very small fraction of the population had access to higher education, and as such, the MPs were a highly selected group of educated men. We also build an indicator variable coding whether they carried out a Grand Tour. The Grand Tour was the educational rite of passage for the members of the British aristocracy in their early 20 s to get them acquainted with classical and contemporary art and culture in Continental Europe, in particular in France and in Italy (Trease 1967; Hibbert 1987). The Grand Tour might also be viewed as a proxy for some open-mindedness and interest in continental philosophy and political ideas (see in particular, Mitchell (2005, Chap. 5) on the Whigs' bond with France). Almost $10 \%$ of the MPs had taken the Grand Tour. We also record the number of years that a MP had served in the House of Commons by 1831 which can be interpreted as a measure of experience. The average length of tenure in the 1830-31 parliament was 11 years. The occupations of the MPs also reflect the aristocratic nature of the pre-1832 Parliament: they were army officers, jurists or lawyers, bankers, industry owners, merchants or landowners. Some of them were "dynasty heirs", in other 
words, MPs who were immediately returned to Parliament when they finished their education and/or reached majority. Finally, many had family members who also held seats.

Relationships amongst the control variables

Tables 4 and 5 report descriptive statistics to highlight the relationship among the control variables. In Table 4, we report correlation coefficients between selected explanatory variables along with their significance levels. We notice that the control variables are not particularly highly correlated. The correlation coefficient between Whig/Radical and Patronage is -0.19 and that between Whig/Radical and Rotten is -0.18 (both coefficients are significant at the $1 \%$ level). In Table 5, we report mean comparisons tests of differences in the constituency characteristics for the sub-samples of constituencies with Whig/Radical and Tory MPs. We find that constituencies which returned Whigs did not, in general, experience significantly more protests than those which returned Tories, but the type of protest did vary. In particular, there were more violent urban unrest, more meetings and a greater number of pro-reform petitions in constituencies that elected Whigs and more violent rural unrest in constituencies that elected Tories. The two tables confirm that more Tories were returned in rotten boroughs and in constituencies controlled by patrons while more Whigs were elected in urban constituencies where elections were somewhat open.

\section{EMPIRICAL STRATEGY}

To test the Threat of Revolution, the Public Opinion and the Political Expedience Hypotheses, we relate violent unrest, peaceful protest and petitions, and political expedience to each MP's vote for or against reform and estimate the following probit model: 


$$
\begin{aligned}
& \operatorname{Prob}\left(\text { yes vote }_{k, d, c}=1\right) \\
& \qquad \begin{array}{l}
=\Phi\left(\alpha_{0}+\text { threat }_{c} \alpha_{1}+\text { opinion }_{d, c} \alpha_{2}+\text { expedience }_{d, c} \alpha_{3}\right. \\
+
\end{array} \\
& \left.+X_{k, d, c} \alpha_{4}\right),
\end{aligned}
$$

where $\Phi$ is the distribution function of the standard normal distribution, yes vote is equal to one if MP $k$ elected in constituency $d$ in county $c$ voted in favor of the bill, and zero if he opposed it. The vector threat represents combinations of the various measures of violent unrest (violent unrest, rural violent, urban violent); the vector opinion collects combinations of the variables that proxy for public opinion (peaceful protest, meetings, gatherings, reform agitation and petitions); the vector expedience collects the four measures of political expedience (net seat gain, disenfranchised, Patron controlled, and landed interest); and the vector $X$ represents the control variables (which are, in the main specification, local newspapers, emp. Herfindahl index, and population density). We control for Whig/Radical in all specifications.

The model is hierarchical: seats belong to constituencies which are located within counties. Since our main explanatory variables are measured at the county or the constituency level, they are perfectly correlated within those clusters. It is also likely that the errors are correlated for seats and constituencies within a given county. To avoid basing inference on standard errors which are likely to be downwards biased, we report standard errors that are clustered at the county level (Cameron and Miller 2015).

Nine Whigs and nine Tories from England were not present in Parliament for the vote on 22 March 1831. The date for the second reading of the bill was known in advance and the second reading itself followed several days of debates. It is unlikely that any of the absent MPs were unaware of the intensity of the discussions in the House of Commons or that they would be uninformed about when the final vote would approximately take place. Since any one of the 
absent MPs could have been pivotal in the vote had they been present, it is important to consider their participation decision. For most of them, we know why they were not present. Table 9, which provides detailed information on this question for each of the absent MPs, shows that by far the most common reason was poor health or planned absence to attend to private business. Yet, it is possible that the decisions of some of these MPs (not) to attend Parliament on that day and (not) to vote on the bill were taken jointly. For example, the absent MPs might have decided not to attend because they did not have any personal stake in the reform, or because they, as in the case of William Henry Little Earle Bulwer, did not want to confront their patron, or because they were discouraged from taking the trip to London by fear of social unrest. If this were the case, our estimates of equation (1) would suffer from a selection bias. We can correct for such a bias using a Heckman-Probit model (Van de Ven and van Pragg 1981). This entails estimating a selection equation which models the probability of being present for the vote and then adjusting the outcome equation (equation (1)) for the selection effect. We consider that two variables can be excluded from the outcome equation because they explain the MPs' presence in the House of Commons for the vote, but are (plausibly) unrelated to the MPs' vote decisions. First, the distance from a MP's constituency to London directly affected how cumbersome it was to get to London, if he was not residing at the time in his London residence, but arguably did not have any direct impact on the vote decision. Second, the MP's age would be a factor and it is reasonable to suppose that old age could explain why a MP was not present at 3 am in the morning when the vote was taken. We thus write the selection equation of the Heckman-Probit model as

$$
\begin{gathered}
\operatorname{Prob}_{\left(\text {present }_{k, d, c}=1\right)}=\Phi\left(\beta_{0}+\text { threat }_{c} \beta_{1}+\text { opinion }_{d, c} \beta_{2}+\text { expedience }_{d, c} \beta_{3}+\right. \\
\text { distance } \left._{d} \beta_{4}+\text { age }_{k} \beta_{5}+X_{k, d, c} \beta_{6}\right)
\end{gathered}
$$

where $\Phi$ is the distribution function of the standard normal distribution, present is equal to one if MP $k$ elected in constituency $d$ in county $c$ was present in the House of Commons on 22 March 1831, and equal to zero if he was not. The variable distance is the inverse crow-fly 
distance (in kilometers) from each constituency to London and age is a second degree polynomial in the age of the MP. The other variables are defined as above.

\section{RESULTS}

\section{Public protest versus political expedience}

In Table 6, we start by presenting our estimates of the effect of all protest and of the four variables capturing political expedience (net seat gain, disenfranchised, Patron controlled, and landed interest) on the probability that the 466 English MPs present voted in favor of the Reform Bill on 22 March 1831. In this and subsequent tables, we report marginal effects evaluated at the mean of the explanatory variables. Column 1 reports a parsimonious specification, while we progressively add controls in columns 2 and 3 . Column 4 reports the results from a sample which is extended with the seats in Wales. Columns 5 and 6 report results from the Heckman-Probit model.

The results show that public protest mattered. The point estimate on all protest is significant at the 5 percent level, the coefficient is stable, and it does not matter if Wales is included in the sample or not. Intuitively, if the home county of a MP had been exposed to an increase of one standard deviation in the number of protest participants $(58,000)$, this would have increased the probability that he voted in favor of the reform bill by 8.7 percentage points (Table 6, column 3). The regression results also suggest that political expedience, as proxied by the net seat gain, disenfranchised, patron controlled and landed interest variables, mattered for the MPs' vote decisions. In the preferred specification in column 3, MPs representing the landed interest were 27 percentage points more likely to support the bill than other MPs. MPs from constituencies in counties that stood to gain additional representation were also more likely to vote for reform: an increase in net seat gain of one increased a MP's likelihood of supporting reform by 0.7 percentage points. In contrast, neither the MPs elected in the "rotten" boroughs which stood to lose representation (disenfranchised), nor those 
elected in constituencies dominated by a local patron (patron controlled) were more likely than the other MPs to oppose the bill.

Further inspection of Table 6 confirms that Whig and Radical MPs were much more likely to support reform than Tory MPs, as indicated by the positive and significant sign of Whig/Radical. This variable controls for the ideological predisposition of the MPs and so, the probit regressions estimate how public protest and political expedience caused the MPs to deviate from this pre-disposition or the wishes of the party leaderships. We also observe that MPs from constituencies with a higher employment Herfindahl index, and thus with a more concentrated employment structure, were more likely to oppose parliamentary reform. Local newspapers and population density are negatively correlated with the support for reform, but not significant. Column 3 includes the only personal characteristic that was significantly related to the MP's vote decision: MPs with an army career were 16 percentage points less likely to support the bill than other MPs. ${ }^{26}$

Table 6, columns 5 and 6, report the result of the Heckman-Probit model that accounts for self-selection regarding the presence of MPs in the House of Commons on 22 March 1831. The three variables used to identify the selection equation (column 6) have the expected signs, but the (inverse) distance to London is not significant. The polynomial in age is, however, significant and suggests a sharp decline in the attendance probability around the age of 41 years. The selection correction has little influence on the outcome equation (column 5) and the results related to protest and political expedience are not modified except for the fact that net seat gain become insignificant.

\footnotetext{
${ }^{26}$ In Table A4 in the online appendix, we report Probit estimations that include all the various personal characteristics (age, experience in parliament, occupation and social circumstances) and after applying a general-to-specific algorithm only army career is significant at the 10 percent level.
} 
Finally, in Table A1 in the online appendix, we reproduce the result of column 3 in Table 6 but with different coding of the main variables. The results are similar when, instead of the number of participants in protest, we use the number of protests, the number of protesters per capita and the number of protesters per adult male. Furthermore, net seat gain has a positive and significant effect when we recode it in percent.

\section{Violent unrest and peaceful protest}

The results reported in Table 6 support the Political Expedience Hypothesis and demonstrate that overall exposure to public protest - a combination of violent unrest and peaceful protest - increased support for the reform bill. In Table 7, we present results related to the Threat of Revolution Hypothesis and the Public Opinion Hypothesis by making a distinction between violent unrest and peaceful protest and by further disaggregating violent unrest into rural and urban violence and peaceful protest into meetings, gatherings and reform agitation. Since some of these variables are highly correlated (see Table A6 in the online appendix), we enter them one by one before presenting a "horse race" regression.

In Table 7, columns 1 and 2, we disaggregate all protest into violent unrest and peaceful protest. We see that the positive effect of violent unrest is imprecisely estimated while peaceful protest influenced the MPs' vote decisions, with an extra 10,000 peaceful protesters increasing the MPs' support for reform by 1.6 percentage points. The further decomposition of violent unrest in Table 7, columns 3 and 4 into rural violent and urban violent, however, shows that urban violent had a significant and large positive effect of the probability of voting yes, while rural violent did not have an effect. We see that an extra 10,000 participants in violent unrest in urban areas increased the MPs' support for reform by 24 percentage points. These results are consistent with the threat of revolution hypothesis and suggest that what the elite feared most was an urban uprising. It is also consistent with the observation that many MPs did not reside in the countryside for most of the winter months, 
even if they owed property there (as we noted above). Consequently, many of them had not been directly exposed to the Swing riots (in the winter of 1830-31) which were the largest violent rural revolt in our sample period.

Table 7, columns 5 and 6 disaggregate peaceful protest into two different types: meetings and gatherings. Both types of protest had a positive effect on the MPs' votes: they increased the support for reform by 2.1 and 1.7 percentage points, respectively, with an extra 10,000 participants. In Table 7, column 7, we single out those meetings and gatherings which Horn and Tilly (1988) identified as being explicitly related to the reform question and we see a highly significant positive effect of this type of agitation. The point estimate on reform agitation suggests that an extra 10,000 participants in reform-related agitation and mass protest would have increased support for reform by 2.5 percentage points. Furthermore, Table 7, column 8 shows that petitions in favor of reform originating from a constituency increased the probability of a yes vote from the MPs elected in that constituency by 0.027 percentage points per additional petition. In all these specifications, we consider one (unrest or protest) variable at the time. In Table 7, column 9, we report the results of a "horse race" specification which pitches the two variables rural violent and urban violent that capture the threat of revolution against the two variables reform agitation and petitions that capture peaceful reform-specific agitation and lobbying. We find that petitions and reform agitation are statistically significant while rural violent and urban violent are not. This suggests that peaceful agitation or lobbying aimed specifically at the reform question had a stronger influenced on the MPs than urban unrest and the fears of revolution that such unrest may have conjured up. ${ }^{27}$

\footnotetext{
${ }^{27}$ As a complement to the econometric analysis, we discuss in the online appendix the importance of the threat of revolution, public agitation, lobbying and mass-mobilization, and political expedience as perceived by the participants themselves and contemporaneous observers by drawing on the transcripts of the debates in the
} 
Table A3 in the online appendix reports additional regression results where we exclude the MPs elected in the City of London, in Westminster and in the county of Middlesex. The motivation for this robustness check is that London was the capital and was consequently, along with its immediate vicinity, the center of political agitation. The results are less precisely estimated, but otherwise similar to those reported in Table 7.

\section{Two counterfactual scenarios}

We present two counterfactual scenarios that are designed to assess the magnitude of the estimated effects and to evaluate if the threat of revolution, public opinion and political expedience exerted a sufficiently powerful effect on the MPs to be considered pivotal in the outcome of the vote. In the first counterfactual scenario, we analyze what would have happened if the MPs who attended the second reading on 22 March 1831 had been exposed to other levels of violent unrest (urban violent) and reform related agitation (reform agitation and petitions) than the actual levels they were exposed to, ranging from the lowest to the highest percentiles of the respective distributions. We also analyze what would have happened if the significant variables related to political expedience (net seat gain and landed interest) had taken different values. For each variable, we determine its value at the $1^{\text {st }}, 10^{\text {th }}$, $25^{\text {th }}, 50^{\text {th }}, 75^{\text {th }}, 90^{\text {th }}$ and $99^{\text {th }}$ percentile of the distribution and use the relevant probit regression to compute the predicted probability that each MP would have voted for reform. ${ }^{28}$

\footnotetext{
House of Commons and in the House of Lords, newspaper reports and private letters, as well as secondary sources.

${ }^{28}$ We use the results in Table 6, column 3 and Table 7, columns 4, 7 and 8. In Table A9 in the online appendix, we report the corresponding results for all protest, peaceful protest, meetings and gatherings. We do not report the results for the variables which were not statistically significant (violent unrest, rural violent, disenfranchised and patron controlled).
} 
For each percentile of the distribution and each variable, Table 8 presents two sets of results: (i) the predicted share of English MPs who would have supported reform had they been exposed to various levels of violent urban unrest, reform agitation and petitions or political expediency and (ii) the predicted number of pro-reform English MPs. For each estimate, we also report $95 \%$ confidence intervals to quantify the precision of the estimates. ${ }^{29}$ We recall that a minority of 229 (out of 466 present) English MPs actually voted for reform (see Table 1). Table 8, column 1 shows the results for the proxy for the threat of revolution, urban violent. This counterfactual scenario shows that, had the MPs been exposed to violent urban unrest in the $75^{\text {th }}$ percentile of the distribution rather than in in the $25^{\text {th }}$, this would have persuaded (with 95 percent confidence) between eight and eleven more of them to support the reform bill and almost created a majority (49.81 percent) in favor of the reform amongst the English MPs. Table 8, columns 2 and 3 report the results for reform related agitation and lobbying. For reform agitation and petitions, a move from the $25^{\text {th }}$ percentile to the $75^{\text {th }}$ percentile would have encouraged, on average, 3 and 10 more MPs to support the reform bill, respectively. It is, therefore, clear that urban violent unrest as a proxy for the threat of revolution as well as peaceful-reform related agitation and petitioning had a substantive effect on the outcome of the second reading and could have been pivotal.

Table 8, columns 4 and 5 evaluate the importance of the two (statistically significant) variables, net seat gain and landed interest, related to political expedience. From Table 8, column 4 , we see that if all constituencies had been located in a county that were to gain two extra seats (corresponding to the $75^{\text {th }}$ percentile of the distribution of net seat gain), then a majority of 234 English MPs would have voted for the bill. Likewise, in Table 8, column 5, we see that had all constituencies enjoyed the benefit that the landed interest obtained from the new voting rules in the counties (corresponding to the $90^{\text {th }}$ percentile of the distribution of

\footnotetext{
${ }^{29}$ The standard errors are calculated with the delta method.
} 
landed interest), 275 of the English MPs would have voted in favor of reform. Political expedience, thus, also had a substantive effect on the outcome of the vote.

In the second counterfactual scenario, we focus on the 18 absent English MPs and analyze what would have happened to the outcome of the vote if they had attended the second reading and voted on 22 March 1831 . Based on the bibliographic information, ${ }^{30}$ we researched the reasons given for each MP's absence which we summarize in Table 9. The two most frequent reasons were (i) poor health and (ii) planned absence. To undertake the counterfactual calculation, we use the probit regression from Table 6, column 3 to predict how the 18 MPs, given their observable characteristics and those of their constituencies, would have voted had they been present. The last column of Table 9 reports for each MP the predicted probability that he would have voted for reform. Eight of the MPs were almost sure to vote yes with a predicted probability of doing so greater than 90 percent and five MPs were almost sure to vote no with a predicated probability of supporting the bill less than 10 percent. Of the remaining five absent MPs, one would in all likelihood have voted yes (with a predicted probability of 87 percent), while the other four would most likely have voted no with probabilities of voting yes between 18 and 38 percent. It, thus, appears that the absent MPs would have split equally between yes and no and that it, therefore, did not matter for the outcome of the vote that they did not attend. It is, however, interesting to observe that out of the nine potentially pro-reform MPs, seven were Whigs and two were Tories. In fact, these two Tories have a high predicted probability of supporting reform: Bethell Walrond has a 87 percent predicted probability of voting yes while that of Charles Vere Ferrars Compton

\footnotetext{
${ }^{30}$ The source for this information is Fisher (2009) and the material available online at http://www.historyofparliamentonline.org/ (accessed 17 September 2017). We acknowledge that the reasons given in the bibliographical sources for the absence may contain some element of ex post rationalization and should be interpreted with that in mind.
} 
Townshend is 98 percent. ${ }^{31}$ Likewise, one of the Whigs, William Henry Lytton, has a very low predicted probability of voting yes (only 2 percent).

\section{Interpretation}

We find strong evidence that the MPs reacted to public expressions of reform support, as suggested by the Public Opinion Hypothesis. Our empirical analysis suggests that two channels connected the MPs to public opinion. The first channel was direct and targeted lobbying via petitions from the MPs' constituents about the reform question. This suggests that lobbying worked, not on every MP, but on a sufficiently large number to make a difference. The other channel is mass-mobilization for reform. Information about massmobilization reached the MPs through their own participation in meetings and through frequent reports in the local and national press about meetings and demonstrations in their home county. Taken together, we conclude that the force of lobbying, agitation and public expressions of reform support were pivotal in pushing the reform bill over its first hurdle. Interests outside of parliament played a key role.

In contrast and despite the rhetoric used by many MPs in the Parliamentary debate and the subsequent narrative of the Whig historians (e.g., McCarthy 1852; Trevelyan, 1920), our "horse race" tests suggest that the threat of revolution played a secondary role compared to public opinion. If anything, it was violent riots and demonstrations in London and in other urban areas rather than the rural Swing riots that made an impression. This does not mean that the threat of revolution was unimportant to the overall reform process: Aidt and Franck (2015) show that it did matter in relation to the April-June 1831 general election called

\footnotetext{
${ }^{31}$ Table A8 in the online appendix reports a counterfactual analysis for the 18 absent MPs similar to the one we reported in Table 8 for the MPs present. We find that low levels of protest would have led nearly $60 \%$ of the 18 absent MPs to support reform but only extreme levels of protest would have led all of them to support it had they been present.
} 
shortly after the second reading where exposure to rural riots generated reform support amongst the electors of the Unreformed Parliament. However, our results suggest that the reform bill passed over its first hurdle, not so much because of fears of revolution, but thanks to the force of peaceful agitation and public expressions of reform support.

The reform process played out against the backdrop of the economic transition to new manufacturing processes that started in the 1760s. In 1830, there was a new industrial elite which was poorly represented in the House of Commons, despite its economic power. This caused tension between the old landed elite and the new industrial elite, not only about political representation (Ansell and Samuels 2014) but also about trade and other economic policies (Schonhardt-Bailey 1991; 1994). Inside the Unreformed Parliament, however, our results related to political expedience suggest that this issue was resolved by the compromises embedded in the reform bill (in other words, more seats to the counties and new seats to the industrial heartland). This made room for a coalition between the MPs elected in the counties, who represented the landed interest, and the MPs elected in the industrial heartland, who represented the industrial interest. Our estimates show that both groups were more likely to support the second reading of the bill. The inter-sectoral coalition building can also be seen from the occupations of the pro- and anti-reform MPs. Table 10 shows simple mean comparison tests of the proportion of the MPs who voted for and against the bill across different occupational and landownership categories. We see that the proportion of MPs with a background in industry (industrialists) was twice as large amongst the supporters as amongst the opponents of the bill. At the same time, the share of landowners was also higher amongst the bill supporters. The anti-reform bloc, however, had a high proportion of MPs with a career in the army or in law. These results suggest that political expedience partly reflected a direct personal interest in the outcome of the reform process and partly underlying sector interests. 


\section{OMITTED FACTORS AND INDIRECT CHANNELS}

Our regression results suggest that public opinion, political expedience and to a lesser extent urban violent unrest directly influenced the MPs' support for reform. We can plausibly rule out reverse causality since our sample of violent unrest, protests and petitions ends before the MPs voted on the reform, although for petitions there could be, as we discuss below, an anticipation effect. The main concern, therefore, is unobserved factors that could explain, at the same time, the spatial distribution of public protest of various types and petitions as well as the MPs' position on the reform bill. Table A5 in the online appendix shows that including an additional set of potentially confounding factors does not affect our results. In this section, we discuss the possibility of indirect effects, anticipation effects, and conduct a placebo test to bolster the argument that the results are not due to unobserved omitted factors.

\section{Direct and indirect influences on the MPs' vote choices}

Tables 6 and 7 report estimates of the direct effect of violent unrest, peaceful protest and political expedience on the MPs' votes. Support and opposition to the bill split, as noted above, along party lines, with the Whigs and Radicals being (mostly) in favor and the Tories being (mostly) against. The MPs who voted on the bill were elected in the 1830 general election. Unlike the election in 1831, parliamentary reform was not yet the major issue when the polling period ended in September 1830. It did play, however, some role in the agitation: the radical politician Henry Hunt stood unsuccessfully in Preston on a reform platform and some of the successful candidates, including Whig politician Henry Brougham, were committed to seek reform in the upcoming session (Brock 1973, Ch. 3; Tilly 1995, p. 324). It 
is, therefore, possible that public protest before and during the electoral campaign induced some voters and patrons in areas strongly affected by protest or agitation to elect candidates from a particular party who subsequently happened to vote in a particular way on the Reform bill. If this were the case, public protest exerted an indirect influence on the vote and the evidence on the direct effect of public protest could reflect this.

To investigate whether public protest and/or expectations of eventual gains and losses from parliamentary reform influenced the outcome of the 1830 election, we create the new dependent variable Whig share in 1830. It is equal to the share of seats in each constituency won by the Whigs or Radicals, in other words, the two parties which subsequently supported the Reform Bill. We also re-compute our measures of public protest so that they only include events which happened before the polling period of the 1830 General Election that started on 29 July 1830. Descriptive statistics are reported in Table A13 in the online appendix.

Table 11 shows the results from three linear regressions relating Whig share in 1830 to our recoded measures of protest, as well as to the variables capturing political expedience and the set of control variables. We find that neither violent unrest nor peaceful protest had any effect on the electoral outcome in 1830 . With regard to political expedience, we see that net seat gain and disenfranchised are insignificant and landed interest is only marginally significant at the ten percent level. The variable Patron controlled is, however, significantly and negatively related to the share of elected Whigs. The places that were controlled by patrons tended to elect Tories, as previously noted. Overall, these results reinforce our interpretation of the main results as evidence that protest in its various forms had a direct effect on the vote choices of the MPs.

Another concern is that petitions were submitted to MPs who were supporting the reform anyway. Since most Whig MPs voted for the reform, we would expect, if this concern is real, a positive correlation between the petitions for reform submitted (largely) after the 
1830 election and the likelihood that a Whig (or Radical) candidate was elected in 1830. In Table 11, column 4, we report that the correlation between petitions and Whig share in 1830 is insignificant, strongly suggesting that this was not the case.

\section{Protest in 1828-1831 and earlier reform attempts}

To further check that our results are not driven by omitted factors correlated with the geography of protests and with the general pro-reform attitudes of the patrons, voters and MPs in each constituency, we propose a falsification test. Its purpose is to assess whether public protests between 1828 and 1831 can predict the roll call votes on two earlier attempts at reform which failed to obtain a majority in the House of Commons. The attempts are the reform bills proposed by Thomas Brand, which was supported by 92 MPs on 21 May 1810 (1807 Parliament), and by Lord John Russell, which was supported by 148 MPs on 25 April 1822 (1820 Parliament). Since protests between 1828 and 1831 had not yet happened, they should not predict whether the MPs in 1810 and 1822 voted for reform. ${ }^{32}$

To carry out the falsification test related to the failed attempts at reform in 1810 and 1822, we estimate probit regressions similar to equation (1) but with the two new dependent variables yes vote 1810 and yes vote 1822 which are equal to one if the MP elected in a given constituency supported the reform bill in 1810 or 1822 , respectively, and zero otherwise. To match the control variables to the relevant time periods, we collect data on the party affiliations of the MPs who represented each English constituency in the 1807 and 1820

\footnotetext{
${ }^{32} \mathrm{We}$ selected these two bills because they received the largest number of favorable votes in the two decades before the Great Reform Act (Cannon, 1973). The yes votes are reported in Hansard, House of Commons, 1810 (vol. 15) and Hansard, House of Commons, 1822 (vol. 7). For all the failed attempts at reform during the $19^{\text {th }}$ century, only the votes in favor of reform are recorded in the Journals of the House of Commons. Therefore, our test can only be carried out for the two attempts in 1810 and 1822 which gathered a sufficiently large number of votes in favor of reform.
} 
Parliaments. We also re-compute the patronage index by assessing whether there was an actual contest in the last seven general elections prior to the 1807 or 1822 general election and use information from the 1811 and 1821 Censuses to construct emp. Herfindahl index and population density. Descriptive statistics are reported in Table A14 in the online appendix. Table 12 shows the results. It is reassuring to observe that neither public protest between 1828 and 1831, whether violent or not, nor reform petitions predict support for reform amongst the MPs in 1810 and 1822. These results provide additional support for our interpretation that the effect of public protest on the second reading of the bill is causal rather than co-incidental.

\section{CONCLUSION}

Our study of the 22 March 1831 roll call vote on parliamentary reform adds to the understanding of the historical process of democratization in three ways. First, in between the view that democratization was an elite project devised for opportunistic reasons and the view that democracy was unwillingly conceded by the elite to avoid a revolution, there is a third possibility which has received too little attention in the historical discourse on democratization, with the notable exception of the pioneering work by Tilly $(1995,2007)$. This possibility is that peaceful protest and demonstrations, agitations, petitioning and other public expressions of opinion might influence the views and attitudes of the elite politicians who contemplate reform without necessarily stoking fears of a violent revolution. In particular, politicians may be influenced by demands from the population at large (e.g., a large peaceful demonstration), from meetings with their constituents, or from organized special interest groups (e.g., lobbying by a reform society) and persuaded that reform is needed and desirable. This sort of mass-led, non-violent mobilization was instrumental in bringing about democratization in several countries in South Asia, Eastern Europe and SubSaharan Africa in the last 30 years (e.g., Bunce and Wolchik, 2006; Chenoweth and Stephan 
2009, 2011). However, there is, as far as we know, no quantitative historical evidence on mass-led democratization. Building on the work by Tilly (1995), our study provides such evidence. We are able to distinguish between peaceful and violent protest and thus between agitation and revolutionary threats. We find that peaceful protest and reform related petitions exerted an important influence on the MPs' vote, giving reason to reassess the importance of mass mobilisation and lobbying for democratic reform. The threat of revolution was stoked by urban (and not rural) social unrest but was less important than peaceful reform related agitation and lobbying for the result of the roll call vote.

Second, the study provides new evidence on the importance of political expedience. We follow the approach pioneered by Ziblatt (2008) and use the details of the reform proposal which disenfranchised many borough constituencies, granted representation to all the large industrial towns, and allocated more seats to the counties to measure the expected gains and losses for individual MPs. We find that MPs elected in borough constituencies located in counties that stood to gain representation as well as those representing the counties and the landed interest supported the bill.

Third, franchise reforms are the outcome of complex political processes and multiple hurdles have to be overcome for success. The Great Reform Act is no exception, as it had to overcome at least five such hurdles at each of which it could have failed (e.g., Brock 1973). The fact that there were multiple hurdles points to the possibility that different "causes" political expedience, agitations and mass mobilization, or threats of revolution - may all play a role but with different intensities at different points in the process. In this paper, we study one of the hurdles that the Great Reform Act had to pass - the roll call vote in March 1831 and find that peaceful reform related agitation and lobbying played a leading role. In contrast, Aidt and Franck (2015) study another of these hurdles - the general election in April-June 1831 - and find strong causal evidence that the threat of revolution as measured by voters' 
exposure to rural riots was instrumental in returning the large Whig majority needed to move the reform process on. This specific example carries with it the more general lesson that different causal mechanisms can be at play at different points during a reform process. This observation not only help resolve why micro-historical studies of the same reform process often arrive at apparently contradicting conclusions, but also explains why particular reforms can deliver case-study evidence in support of very different theories of suffrage reform. 


\section{REFERENCES}

Acemoglu, Daron, and James A. Robinson, "Why Did the West Extend the Franchise? Democracy, Inequality, and Growth in Historical Perspective." Quarterly Journal of Economics 115, no. 4 (2000): 1167-1199.

"'Persistence of Power, Elites, and Institutions." American Economic Review 98, no. 1 (2008): 267-93.

Aidt, Toke S., and Raphaël Franck, "How to Get the Snowball Rolling and Extend the Franchise: Voting on the Great Reform Act of 1832." Public Choice 155, no. 3-4 (2013): $229-250$.

, "Democratization under the Threat of Revolution: Evidence from the Great Reform Act of 1832.” Econometrica 83, no. 2 (2015): 505-47.

Aidt, Toke S, and Raphaël Franck. "The Great Reform Act of 1832, United Kingdom”. Ann Arbor, MI: Inter-university Consortium for Political and Social Research [distributor], (2019). https://doi.org/10.3886/E108281V2.

Aidt, Toke S., Martin Daunton, and Jayasri Dutta, “The Retrenchment Hypothesis and the Extension of the Franchise in England and Wales.” Economic Journal 120, no. 547 (2010): 990-1020.

Aidt, Toke S., and Peter S. Jensen. "Workers of the World, Unite! Franchise Extensions and the Threat of Revolution in Europe, 1820-1938." European Economic Review 72 (2014): 52-75. "From Open to Secret Ballot: Vote Buying and Modernization" Comparative Political Studies, 50 (2017): 555-593. 
Ansell, Ben, and David Samuels, "Inequality and Democratization: A Contractarian Approach." Comparative Political Studies 43 (2010): 1543-1574. , Inequality and Democratization: An Elite-competition Approach. Cambridge, UK: Cambridge University Press, 2014.

Austen-Smith David. "Strategic Transmission of Costly Information.” Econometrica 62 (1994): 955-63.

Aydelotte, William O., "The Country Gentlemen and the Repeal of the Corn Laws." English Historical Review 82, no. 322 (1967), 47-60.

Bennedsen Morten, Feldmann Sven E. "Informational Lobbying and Political Contributions," Journal of Public Economics 90 (2006): 631-56.

Barker, Hannah, Newspapers, Politics and English Society, 1695-1855. New York, NY: Longman, 2000.

Berlinski, Samuel, and Torun Dewan, "The Political Consequences of Franchise Extension: Evidence from the Second Reform Act." Quarterly Journal of Political Science 6, no. 34 (2011): 329-376.

Blaug, Mark, "The Myth of the Old Poor Law and the Making of the New." Journal of Economic History 23, no. 2 (1963): 151-184.

Bohstedt, John, The Politics of Provisions Food Riots, Moral Economy, and Market Transition in England, c. 1550-1850. London, UK: Ashgate, 2010.

Boix, Carles, Democracy and Redistribution. Cambridge, UK: Cambridge University Press, 2003. 
Boyer, George, An Economic History of the English Poor Law, 1750-1850. Cambridge, UK: Cambridge University Press, 1993.

Brock, Michael G., The Great Reform Act. London: Hutchinson University Library, 1973.

Brückner, Markus, and Antonio Ciccone, "Rain and the Democratic Window of Opportunity." Econometrica 79, no. 3 (2011): 923-947.

Bunce, Valerie J., and Sharon L. Wolchik, "Favorable Conditions and Electoral Revolutions." Journal of Democracy 17, no. 4 (2006): 5-18.

Burke, Paul J., and Andrew Leigh, "Do Output Contractions Trigger Democratic Change?." American Economic Journal: Macroeconomics 2, no. 4 (2010): 124-157.

Cameron, A. Colin, and Douglas L. Miller, “A Practitioner's Guide to Cluster-Robust Inference." Journal of Human Resources 50, no. 2 (2015): 317-372.

Cannon, John A., Parliamentary reform, 1640-1832. Cambridge, UK: Cambridge University Press, 1973.

Capoccia, Giovanni, and Daniel Ziblatt, “The Historical Turn in Democratization Studies: A New Research Agenda for Europe and Beyond.” Comparative Political Studies 43, no. 8 (2010): 931-968.

Chenoweth Erica, and Maria J. Stephan, Why Civil Resistance Works: The Strategic Logic of Nonviolent Conflict. New York, NY: Columbia University Press, 2011. , "Why Civil Resistance Works: The Strategic Logic of Nonviolent Conflict." International Security 33, no. 1 (2009): 7-44. 
Collier, Ruth B., Paths toward Democracy. The Working Class and Elites in Western Europe and South America. Cambridge, UK: Cambridge University Press, 1999.

Congleton, Roger D., "From Royal to Parliamentary Rule without Revolution: the Economics of Constitutional Exchange within Divided Governments." European Journal of Political Economy 23, no. 2 (2007): 261-284.

, Perfecting Parliament. Cambridge, UK: Cambridge University Press, 2011.

Conley, John P., and Akram Temimi, “Endogenous Enfranchisement when Groups' Preferences Conflict.” Journal of Political Economy 109, no. 1 (2001), 79-102.

Crawford, Vincent P., and Joel Sobel. "Strategic Information Transmission.” Econometrica 50(6) (1982): 1431-1451.

Dasgupta, Aditya, and Daniel Ziblatt, "How did Britain Democratize? Views from the Sovereign Bond Market.” Journal of Economic History 75, no. 1 (2015): 1-29.

Dincecco, Mark, Giovanni Federico, and Andrea Vindigni. "Warfare, Taxation, and Political Change: Evidence from the Italian Risorgimento.” Journal of Economic History 71 (2011): 887-914.

Do, Quoc-Anh and Filipe R. Campante (2009). "Keeping dictators honest: The role of population concentration”, Governance Working Papers 22076, East Asian Bureau of Economic Research.

Dorsch, Michael T., and Paul Maarek, "Inefficient Predation and Political Transitions." European Journal of Political Economy 37, (2015): 37-48. 
Escott, Margaret, 2009, The Procedure and Business of the House, in D.R. Fisher (ed.), The History of Parliament: The House of Commons 1820-1832, Cambridge University Press, Cambridge, UK.

Evans, Eric J., Parliamentary reform, 1770-1918. London, UK: Pearson Education, 2000.

Falkinger, Josef, “Social Instability and Redistribution of Income.” European Journal of Political Economy 15, no. 1 (1999): 35-51.

Fisher, David (ed.), The History of Parliament: The House of Commons 1820-1832, Cambridge, UK: Cambridge University Press, 2009.

Franck, Raphaël, “The Political Consequences of Income Shocks: Explaining the Consolidation of Democracy in France.” Review of Economics of Statistics 98, no. 1 (2016): 57-82.

Grossman, Gene M. and Elhanan Helpman, Special Interest Politics. Cambridge, MA: MIT Press, 2001.

Gundlach, Erich, and Martin Paldam, “A Farewell to Critical Junctures.” European Journal of Political Economy 25, no. 3 (2009): 340-354.

Hammond, J.L. and Barbara Hammond, The Village Labourer. Stroud, UK: Nonsuch Publishing Limited, 1911.

Hibbert, Christopher, The Grand Tour, London, UK: Thames Methuen, 1987.

Hill, Brian, The Early Parties and Politics in Britain, 1688-1832. New York, NY: Macmillan Press, 1996.

Himmelfarb, Gertrude, The Politics of Democracy: The English Reform Act of 1867. The Journal of British Studies 6, no. 1 (1966): 97-138. 
Hobsbawm, E.J., and George Rudé, Captain Swing. Harmondsworth, UK: Penguin University Books, 1973.

Horn, Nancy, and Charles Tilly, Contentious Gatherings in Britain, 1758-1834. Ann Arbor, MA: Inter-university Consortium for Political and Social Research ICPSR working paper 8872, 1988.

Jupp, Peter, British Politics on the Eve of Reform, the Duke of Wellington's Administration, 1828-30. New York, NY: Macmillan, 1998.

Kindleberger, Charles P., "The Rise of Free Trade in Western Europe.” Journal of Economic History 35, no. 1 (1975): 20-55.

Kuran, Timur, "Sparks and Prairie Fires: A Theory of Unanticipated Political Revolution." Public Choice 61, no. 1 (1989): 41-74.

Lehmann-Hasemeyer, Sibylle, Philipp Hauber, and Alexander Opitz, “The Political Stock Market in the German Kaiserreich — Do Markets Punish the Extension of the Suffrage to the Benefit of the Working Class? Evidence from Saxony." Journal of Economic History 74, no. 4 (2014): 1140-1167.

Lizzeri, Alessandro, and Nicola Persico, "Why Did the Elites Extend the Suffrage? Democracy and the Scope of Government, with an Application to Britain's `Age of Reform'.” Quarterly Journal of Economics 119, no. 2 (2004): 707-765.

Llavador, Humberto, and Robert J. Oxoby, "Partisan Competition, Growth, and the Franchise." Quarterly Journal of Economics 120, no. 3 (2005): 1155-1192.

Lohmann Susanne. "Information, Access, and Contributions: A Signalling Model of Lobbying," Public Choice 85 (1995): 267-84. 
Maehl, William Henry, The Reform Bill of 1832. Why Not Revolution?. London, UK: Holt, Rinehard \& Winston, 1967.

Machin, G.I.T., The Catholic Question in English Politics, Oxford, UK: Clarendon Press, 1964.

Mares, Isabela, From Open Secrets to Secret Voting. Democratic Electoral Reforms and Voter Autonomy. Cambridge, UK: Cambridge University Press, 2015.

McCarthy, Justin, The Epoch of Reform 1830-50. London, UK: Longmans, Green \& Co, 1852.

Meirowitz, Adam, and Joshua A. Tucker, "People Power or a One-Shot Deal? A Dynamic Model of Protest.” American Journal of Political Science 57, no. 2 (2013): 478-490.

Mitchell, Austin, The Whigs in Opposition 1815-1830, Oxford, UK: Clarendon Press, 1967.

Mitchell, Leslie, The Whig World. London, UK: Hambledon Continuum, 2005.

Mokyr, Joel, The Enlightened Economy: An Economic History of Britain 1700-1850, New Haven, CT: Yale University Press, 2009.

Namier, Lewis B., and John Brooke, The House of Commons, 1754-1790. Oxford: Oxford University Press, 1964.

Nardinelli, Clark, "Child Labor and the Factory Acts.” Journal of Economic History 40, no. 4 (1980): 739-755.

, Child Labor and the Industrial Revolution. Bloomington and Indianapolis, IN:

Indiana University Press, 1990.

O’Gorman, Frank, Voters, Patrons and Parties: the Unreformed Electoral System of Hanoverian England 1734-1832. Oxford, UK: Oxford University Press, 1989. 
Philbin, J. Holladay, Parliamentary Representation, 1832, England and Wales, New Haven, CT: Yale University Press, 1965.

Przeworski, Adam, “Conquered or Granted? A History of Suffrage Extensions.” British Journal of Political Science 39, no.2 (2009): 291-321.

Rueschemeyer, Dietrich, Evelyne Huber Stephens, and John D. Stephens, Capitalist Development and Democracy. Chicago, IL: University of Chicago Press, 1992.

Seghezza, Elena and Pierluigi Morelli, "Suffrage extension, social identity, and redistribution: the case of the Second Reform Act." European Review of Economic History, In Press, https://doi.org/10.1093/ereh/hey007.

Schonhardt-Bailey, Cheryl, "Domestic Determinants of the Repeal of the Corn Laws" World Politics 43, no. 4 (1991): 545-569.

, "Linking Constituency Interests to Legislative Voting Behavior: The Role of District Economic and Electoral Composition in the Repeal of the Corn Laws," Parliamentary History 13, 1, (1994): 86-118. , From the Corn Laws to Free Trade: Interests, Ideas, and Institutions in Historical Perspective. Cambridge, MA: MIT Press, 2006.

Stevenson, John, Popular Disturbances in England: 1700-1832, London, UK: Routledge, 1992.

Stooks Smith, Henry. The Parliaments of England. Chichester, UK: Political Reference Publications, 1973.

Thompson, E.P., The Making of the English Working Class. New York, NY: Vintage Books, 1963. 
Thorne, R. G., The House of Commons, 1790-1820. Oxford, UK: Oxford University Press, 1986.

Tilly, Charles, Popular Contention in Great Britain, 1758-1834. Cambridge, MA: Harvard University Press, 1995.

, Democracy. Cambridge, UK: Cambridge University Press, 2007.

Trease, Geoffrey, The Grand Tour, New York, NY: Holt, Rinehart and Winston, 1967.

Trevelyan, George Macaulay, Lord Grey of the Reform Bill: Being the Life of Charles, Second Earl of Grey. Greenwood Press, 1920.

, History of England, $2^{\text {nd }}$ edition. London, UK: Longmans, Green \& Co, 1937.

Turner, John D., and Wenwen Zhan. "Property Rights and Competing for the Affections of Demos: The Impact of the 1867 Reform Act on Stock Prices." Public Choice 150, no. 3-4 (2012): 609-631.

Van de Ven, Wynand P.M.M., and Bernard M.S. Van Praag, "The Demand for Deductibles in Private Health Insurance: A Probit Model with Sample Selection.” Journal of Econometrics 17, no. 2 (1981): 229-252.

Ziblatt, Daniel, “How did Europe Democratize?.” World Politics 58, no. 2 (2006): 311-38. , "Does Landholding Inequality Block Democracy? A Test of the "Bread and Democracy” Thesis and the Case of Prussia." World Politics 60, no. 4 (2008): 610-41.

\section{HISTORICAL SOURCES}

Census of Great Britain, 1811, 1821, 1831. 
Dod, Charles R. and Dod, Robert Phipps, Dod's Parliamentary Companion. Hailsham, England: Dod's Parliamentary Companion, ltd., 1832.

Hansard, House of Commons (HC), 1831 (vol. 2 and 3)

Hansard, House of Commons (HC), 1822 (vol. 7).

Hansard, House of Commons (HC), 1810 (vol. 15).

Hansard, House of Lords (HL), 1830 (series 3, vol. 1)

Journals of the House of Commons (1828-1831, vol. 83-86).

House of Commons, Parliamentary Papers, A \& P. Newspaper stamps, England. Return to an order of the Honourable House of Commons, dated 24 May 1833; --for, an Account of the Number of Stamps Issued to each of the Provincial Newspapers in England, in the Year Ending on 1 April 1833. House of Commons Papers, vol. XXXII, (1833a): 613-17.

House of Commons, Parliamentary Papers, A \& P. Newspaper Stamps, London. Return of the Number of Stamps issued by the Stamp Office for all the London Newspapers, from the Commencement of the Year 1832 to 31 March 1833, Inclusive. House of Commons Papers Vol XXXII, (1833b) p. 605-607.

Private letter, J. Hume (British Library ADD 35148, LXXIX, 1 November 1830).

The Times (London, England)

The statutes of the United Kingdom of Great Britain and Ireland. 2 \& 3 William IV. London: His Majesty's statute and law printers. Cap. XLV: “An Act to amend the Representation of the People in England and Wales", (1832) pp. 154-206. 
TABLE 1

THE BREAKDOWN OF THE ROLL CALL VOTE IN THE HOUSE OF COMMONS 22 MARCH 1831, ON THE SECOND READING OF THE REFORM BILL

\begin{tabular}{lccccccccc}
\hline & & \multicolumn{2}{c}{ England } & & Wales & $\begin{array}{c}\text { Scotland } \\
\& \\
\text { Ireland }\end{array}$ & \multicolumn{3}{c}{ United Kingdom } \\
& Whigs & Tory & Radical & Total & $\begin{array}{c}\text { All } \\
\text { MPs }\end{array}$ & $\begin{array}{c}\text { All } \\
\text { MPs }\end{array}$ & $\begin{array}{c}\text { Gross } \\
\text { total }\end{array}$ & $\begin{array}{c}\text { Paired off } \\
\text { and Tellers }\end{array}$ & $\begin{array}{c}\text { Net } \\
\text { total }\end{array}$ \\
\hline Yes & 188 & 37 & 4 & 229 & 14 & 69 & 312 & 10 & 302 \\
No & 8 & 229 & 0 & 237 & 10 & 64 & 311 & 10 & 301 \\
Absent & 9 & 9 & 0 & 18 & 0 & 9 & 27 & & \\
Vacancies & 1 & 3 & 0 & 4 & 0 & 3 & 7 & \\
Speaker & & 1 & & 1 & & & 1 & \\
Total & 206 & 279 & 4 & 489 & 24 & 145 & 658 & & \\
\hline
\end{tabular}

Note: The category "absent" includes the MPs who could have been present but were not. The category "vacancies" refers to seats where a by-election was due. The seats were Evenham (both seats vacant due to bribery), Colchester (one ineligible elected) and Durham City (one ineligible elected), Nairnshire in Scotland (vacated) and Clare (one ineligible elected) and Londonderry (one ineligible elected) in Ireland. The party affiliation refers to the MPs elected in 1830. The Speaker (a Tory, elected in Scarborough) abstained. Eight MPs were paired off and two MPs were appointed Tellers on each side of the issue.

Source: Hansard (1831, vol 2, p. 719-826) contains the division list reporting all votes cast. The party affiliations of the English MPs are constructed from information in Dod and Dod (1832), Namier and Brooke (1964), Stooks Smith (1973), Thorne (1986), and Fisher (2009). 


Obs. Mean Std.Dev. Min. Max.

Support for parliamentary reform

Yes vote (Second Reading of Great Reform Act)

Members of Parliament

Whig/Radical

Age (of MP)

Army Career

Public protest participants

All protest $(10,000 \mathrm{~s})$

Violent unrest $(10,000 \mathrm{~s})$

Peaceful protest $(10,000 \mathrm{~s})$

Rural violent $(10,000 \mathrm{~s})$

Urban violent $(10,000 \mathrm{~s})$

Meetings $(10,000 \mathrm{~s})$

Gatherings $(10,000 \mathrm{~s})$

Reform agitation $(10,000 \mathrm{~s})$

Expected consequences of reform

Net seat gain

Institutional controls

Local newspapers
Seat-Level Variation

$\begin{array}{ccccc}466 & 0.49 & 0.50 & 0 & 1 \\ 485 & 0.43 & 0.50 & 0 & 1 \\ 485 & 44.9 & 13.1 & 21 & 79 \\ 485 & 0.19 & 0.39 & 0 & 1\end{array}$

County-Level Variation

$\begin{array}{ccccc}489 & 3.60 & 5.88 & 0.001 & 25.9 \\ 489 & 0.26 & 0.43 & 0 & 2.98 \\ 489 & 3.34 & 5.68 & 0.001 & 25.6 \\ 489 & 0.11 & 0.21 & 0 & 0.83 \\ 489 & 0.15 & 0.41 & 0 & 2.98 \\ 489 & 1.61 & 2.93 & 0.001 & 16.3 \\ 489 & 1.72 & 4.20 & 0 & 21.1 \\ 489 & 0.71 & 2.12 & 0 & 15.1\end{array}$

$\begin{array}{lllll}489 & -4.01 & 9.51 & -28 & 12\end{array}$

$\begin{array}{lllll}489 & 16.6 & 62.3 & 0 & 303\end{array}$

Constituency-Level Variation

Public protest

Petitions

Expected consequences of reform

Disenfranchised

Patron controlled

Landed interest

Demographic and economic controls

Emp. Herfindahl index

Population density

Distance to London (inverse)

$\begin{array}{ccccc}489 & 1.46 & 2.83 & -2 & 27 \\ 489 & 0.23 & 0.42 & 0 & 1 \\ 489 & 0.76 & 0.43 & 0 & 1 \\ 489 & 0.17 & 0.37 & 0 & 1 \\ & & & & \\ 489 & 0.76 & 0.073 & 0.24 & 0.86 \\ 489 & 5.58 & 0.84 & 3.92 & 9.79 \\ 489 & 0.02 & 0.11 & 0.002 & 0.88\end{array}$

Note: The sample is restricted to the 489 English seats. The statistics for the MPs exclude the four unpresented seats. Definitions and sources of the variables are provided in the text and in online appendix A10. 
TABLE 3

THE NUMBER OF PARTICIPANTS INVOLVED IN DIFFERENT TYPES OF PROTEST BY MAJOR REGIONS, 1 JANUARY 1828 - 22 MARCH 1831.

\begin{tabular}{|c|c|c|c|c|c|c|c|c|}
\hline \multirow[b]{2}{*}{ Region } & \multirow{2}{*}{$\begin{array}{c}\begin{array}{c}\text { All } \\
\text { protest }\end{array} \\
\text { total }\end{array}$} & \multicolumn{3}{|c|}{ Violent unrest } & \multicolumn{3}{|c|}{ Peaceful protest } & \multirow{2}{*}{$\begin{array}{c}\text { Reform } \\
\begin{array}{c}\text { agitation } \\
\%\end{array}\end{array}$} \\
\hline & & all & $\begin{array}{c}\text { rural } \\
\%\end{array}$ & $\begin{array}{c}\text { urban } \\
\%\end{array}$ & all & $\begin{array}{c}\text { meetings } \\
\%\end{array}$ & $\begin{array}{c}\text { gatherings } \\
\%\end{array}$ & \\
\hline Southeast & 154,023 & 20,507 & 73.4 & 26.6 & 133,516 & 48.3 & 51.7 & 10.5 \\
\hline East Anglia & 45,181 & 7,293 & 37.5 & 62.5 & 37,888 & 71.8 & 28.2 & 15.8 \\
\hline Midlands & 252,853 & 16,306 & 3.3 & 96.7 & 236,547 & 46 & 54 & 70.8 \\
\hline Southwest & 133,721 & 6,623 & 94.3 & 5.7 & 127,098 & 32.6 & 67.4 & 7.6 \\
\hline North & 374,192 & 14,519 & 0 & 100 & 359,673 & 38.7 & 61.3 & 26.4 \\
\hline London & 239,294 & 29,756 & 0 & 100 & 209,538 & 77.9 & 22.1 & 20.3 \\
\hline Wales & 3,142 & 40 & 0 & 100 & 3,102 & 25.1 & 74.9 & 2.9 \\
\hline All participants & $1,202,406$ & 95,044 & 25.9 & 74.1 & $1,107,362$ & 49.2 & 50.8 & 30.2 \\
\hline All events & 2,726 & 546 & 39.0 & 61.0 & 2180 & 87.5 & 12.5 & 18.3 \\
\hline Ave. participation & 441 & 174 & 630 & 1155 & 508 & 286 & 2068 & 836 \\
\hline
\end{tabular}

Note: Southeast includes Berkshire, Buckinghamshire, Hampshire, Kent, Oxfordshire, Surrey and Sussex; Southwest includes Cornwall, Devon, Dorset, Gloucestershire, Somerset, Wiltshire and Monmouthshire; East Anglia includes Bedfordshire, Cambridgeshire, Essex, Hertfordshire, Huntingdonshire, Norfolk and Suffolk; Midlands includes Derbyshire, Herefordshire, Leicestershire, Lincolnshire, Northamptonshire, Nottinghamshire, Rutland, Salop, Staffordshire, Warwickshire, and Worcestershire; North includes Cheshire, Cumberland, Durham, Lancashire, Northumberland, Westmorland, and Yorkshire; London includes the City of London, Westminster and Middlesex; Wales includes all the counties of Wales. All protest is equal to violent unrest plus peaceful protest; meetings and gatherings sum to peaceful protest and rural and urban violent sum to violent unrest. Reform agitation is reform-related peaceful events (and expressed in percentage of peaceful protest). Total events record the number of protest events and ave. participation is the number of participants per protest. The number of participants involved in the protest is calculated from Horn and Tilly (1988)'s best estimate and for those protests where they do not have an estimate, we assume that 10 people were involved (this is the cut-off for being included in their database).

Source: Horn and Tilly (1988). 
TABLE 4

CORRELATION COEFFICIENTS AMONG SELECTED SOCIO-ECONOMIC AND POLITICAL CHARACTERISTICS

\begin{tabular}{|c|c|c|c|c|c|c|c|}
\hline & $\begin{array}{l}\text { Net seat } \\
\text { gain }\end{array}$ & Disenfranchised & $\begin{array}{l}\text { Patron } \\
\text { controlled }\end{array}$ & $\begin{array}{l}\text { Landed } \\
\text { interest }\end{array}$ & \begin{tabular}{l} 
Whig\} $\\
{\text { Radical }}$ & $\begin{array}{c}\text { Local } \\
\text { newspapers }\end{array}$ & $\begin{array}{c}\text { Emp. } \\
\text { Herfindahl } \\
\text { index }\end{array}$ \\
\hline Disenfranchised & $-0.363 * * *$ & & & & & & \\
\hline Patron controlled & $-0.228 * * *$ & $0.281 * * *$ & & & & & \\
\hline Landed interest & $0.175 * * *$ & $-0.243 * * *$ & $-0.108 * *$ & & & & \\
\hline Whig \Radical & $0.131 * * *$ & $-0.184 * * *$ & $-0.191 * * *$ & $0.097^{* * *}$ & & & \\
\hline Local newspapers & $0.099 * *$ & 0.019 & $-0.158 * * *$ & 0.006 & 0.051 & & \\
\hline Emp. Herfindahl index & $0.092 * *$ & $-0.224 * * *$ & $-0.120 * * *$ & $0.314 * * *$ & 0.033 & 0.020 & \\
\hline Population density & -0.011 & $-0.091 * *$ & $-0.139 * * *$ & -0.062 & -0.021 & $0.308 * * *$ & 0.066 \\
\hline
\end{tabular}
\end{tabular}

* = Significant at the 10 percent level.

** = Significant at the 5 percent level.

$* * *=$ Significant at the 1 percent level.

Note: Calculated for the sample of 489 English constituencies. 
TABLE 5

TEST OF MEANS DIFFERENCES IN CONSTITUENCY CHARACTERISTICS BY

PARTY AFFILIATION OF THE ELECTED MP

\begin{tabular}{|c|c|c|c|c|c|}
\hline \multirow{2}{*}{ Public Protest } & \multicolumn{2}{|c|}{ Tory } & \multicolumn{2}{|c|}{ Whig/Radical } & $\mathrm{P}$-value \\
\hline & & & & & \\
\hline All Protest & 3.49 & {$[0.34]$} & 3.74 & {$[0.42]$} & 0.64 \\
\hline Violent Unrest & 0.24 & [0.021] & 0.30 & {$[0.036]$} & 0.13 \\
\hline Peaceful Unrest & 3.25 & {$[0.34]$} & 3.45 & {$[0.40]$} & 0.71 \\
\hline Rural Violent & 0.13 & [0.014] & 0.094 & {$[0.012]$} & 0.07 \\
\hline Urban Violent & 0.11 & {$[0.018]$} & 0.20 & {$[0.036]$} & 0.01 \\
\hline Meetings & 1.42 & {$[0.15]$} & 1.88 & {$[0.24]$} & 0.09 \\
\hline Gatherings & 1.84 & {$[0.26]$} & 1.57 & {$[0.27]$} & 0.49 \\
\hline Petitions & 1.20 & {$[0.16]$} & 1.80 & {$[0.21]$} & 0.02 \\
\hline Reform Agitation & 0.69 & {$[0.12]$} & 0.75 & {$[0.15]$} & 0.72 \\
\hline \multicolumn{6}{|c|}{ Expected Consequences of Reform } \\
\hline Neat Seat Gain & -5.09 & {$[0.60]$} & -2.58 & {$[0.60]$} & 0.004 \\
\hline Disenfranchised & 0.29 & [0.027] & 0.14 & [0.024] & 0.000 \\
\hline Patron controlled & 0.83 & [0.022] & 0.67 & {$[0.033]$} & 0.000 \\
\hline Landed interest & 0.14 & [0.021] & 0.21 & {$[0.028]$} & 0.03 \\
\hline \multicolumn{6}{|l|}{ Institutional Controls } \\
\hline Local Newspapers & 13.85 & {$[3.35]$} & 20.21 & {$[4.82]$} & 0.26 \\
\hline \multicolumn{6}{|c|}{ Demographic and economic controls } \\
\hline Emp Herfindahl Index & 0.76 & [0.005] & 0.76 & {$[0.005]$} & 0.47 \\
\hline Population density & 5.59 & [0.049] & 5.56 & [0.061] & 0.65 \\
\hline Distance to London (Inverse) & 0.014 & [0.004] & 0.038 & {$[0.010]$} & 0.02 \\
\hline
\end{tabular}

Note: The table reports average and standard errors (in square brackets) for the subsamples of the 489 English seats identifying with the Tory and the Whig/Radical parties, respectively. We were 279 Tories and 210 Whigs/Radicals. The last column reports the p-value associated with a t-test of the null hypothesis that the means of the two subsamples are different. 
TABLE 6

THE PROBABILITY THAT A MP VOTED IN FAVOR OF THE REFORM BILL ON 22 MARCH 1831: PROBIT AND HECKMAN-PROBIT ESTIMATES

\begin{tabular}{|c|c|c|c|c|c|c|}
\hline \multirow[t]{2}{*}{ Dependent variable } & \multicolumn{3}{|c|}{ Yes vote } & \multirow[b]{2}{*}{ (4) } & \multirow[b]{2}{*}{ (5) } & \multirow{2}{*}{$\begin{array}{c}\text { Present } \\
\text { (6) }\end{array}$} \\
\hline & (1) & (2) & (3) & & & \\
\hline \multirow{3}{*}{ All protest } & & & & Incl. Wales & Heckman-Prob & Selection \\
\hline & 0.014 & 0.015 & 0.015 & 0.015 & 0.016 & -0.34 \\
\hline & $(0.0067)^{* *}$ & $(0.0074)^{* *}$ & $(0.0071)^{* *}$ & $(0.0072)^{* *}$ & $(0.0071)^{* *}$ & $(0.14)^{* *}$ \\
\hline \multirow[t]{2}{*}{ Net seat gain } & 0.0074 & 0.0066 & 0.0071 & 0.0073 & 0.0053 & 0.0029 \\
\hline & $(0.0035)^{* *}$ & $(0.0038)^{*}$ & $(0.0038)^{*}$ & $(0.0039)^{*}$ & $(0.0037)$ & $(0.011)$ \\
\hline \multirow[t]{2}{*}{ Disenfranchised } & -0.066 & -0.090 & -0.099 & -0.099 & -0.068 & -0.44 \\
\hline & $(0.080)$ & $(0.090)$ & $(0.091)$ & $(0.091)$ & $(0.075)$ & $(0.35)$ \\
\hline \multirow[t]{2}{*}{ Patron controlled } & -0.084 & -0.11 & -0.10 & -0.072 & -0.080 & -0.57 \\
\hline & $(0.10)$ & $(0.10)$ & $(0.10)$ & $(0.098)$ & $(0.090)$ & $(0.33)^{*}$ \\
\hline \multirow[t]{2}{*}{ Landed interest } & 0.21 & 0.27 & 0.27 & 0.31 & 0.24 & -0.07 \\
\hline & $(0.070)^{* * *}$ & $(0.065)^{* * *}$ & $(0.065)^{* * *}$ & $(0.062)^{* * *}$ & $(0.060)^{* * *}$ & $(0.27)$ \\
\hline \multirow[t]{2}{*}{ Whig/Radical } & 0.83 & 0.84 & 0.84 & 0.84 & 0.81 & -0.30 \\
\hline & $(0.029)^{* * *}$ & $(0.029) * * *$ & $(0.029)^{* * *}$ & $(0.028)^{* * *}$ & $(0.029)^{* * *}$ & $(0.17)^{*}$ \\
\hline \multirow[t]{2}{*}{ Local newspapers } & & -0.00013 & -0.00020 & -0.00015 & -0.00028 & 0.0027 \\
\hline & & $(0.00032)$ & (0.00029) & $(0.00032)$ & $(0.00027)$ & $(0.0011)^{* *}$ \\
\hline \multirow[t]{2}{*}{ Emp. Herfindahl index } & & -1.03 & -1.18 & -1.07 & -1.05 & 0.69 \\
\hline & & $(0.51)^{* *}$ & $(0.53)^{* *}$ & $(0.52)^{* *}$ & $(0.46)^{* *}$ & $(0.95)$ \\
\hline \multirow[t]{2}{*}{ Population density } & & -0.026 & -0.026 & -0.029 & -0.030 & 0.070 \\
\hline & & $(0.041)$ & $(0.039)$ & $(0.040)$ & $(0.035)$ & $(0.14)$ \\
\hline \multirow[t]{2}{*}{ Army career } & & & -0.16 & -0.11 & -0.10 & -0.57 \\
\hline & & & $(0.087)^{*}$ & $(0.087)$ & $(0.074)$ & $(0.21)^{* * *}$ \\
\hline \multirow[t]{2}{*}{ Distance (inverse) } & & & & & & 18.0 \\
\hline & & & & & & (11.9) \\
\hline \multirow[t]{2}{*}{ Age of MP } & & & & & & 0.062 \\
\hline & & & & & & $\begin{array}{c}(0.034)^{*} \\
-0.00076\end{array}$ \\
\hline Age of MP (squared) & & & & & & $(0.00038)^{* *}$ \\
\hline Observations & 466 & 466 & 466 & 490 & 484 & 484 \\
\hline
\end{tabular}

* = Significant at the 10 percent level.

$* *=$ Significant at the 5 percent level.

$* * *$ = Significant at the 1 percent level.

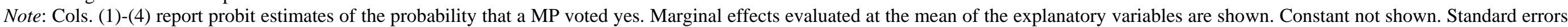

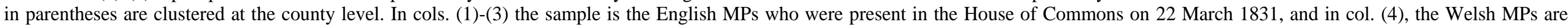

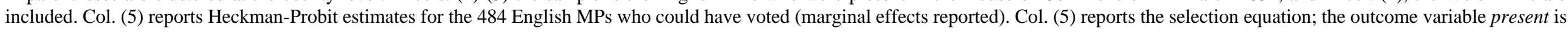

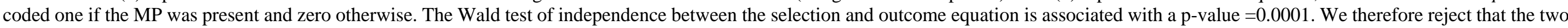
equation are independent and selection may be an issue. 
TABLE 7

THE EFFECT OF VIOLENT AND DIFFERENT TYPES OF PEACEFUL PROTEST ON A MP'S PROBABILITY OF VOTING IN FAVOR OF THE REFORM BILL: PROBIT ESTIMATES

\begin{tabular}{|c|c|c|c|c|c|c|c|c|c|}
\hline \multirow[t]{2}{*}{ Dependent Var. } & \multicolumn{9}{|c|}{ Yes vote } \\
\hline & (1) & (2) & (3) & (4) & (5) & (6) & (7) & (8) & (9) \\
\hline Violent unrest & $\begin{array}{c}0.11 \\
(0.11)\end{array}$ & & & & & & & & \\
\hline Peaceful protest & & $\begin{array}{c}0.016 \\
(0.0075)^{* *}\end{array}$ & & & & & & & \\
\hline Rural violent & & & $\begin{array}{l}-0.19 \\
(0.15)\end{array}$ & & & & & & $\begin{array}{l}-0.20 \\
(0.16)\end{array}$ \\
\hline Urban violent & & & & $\begin{array}{c}0.24 \\
(0.081)^{* * *}\end{array}$ & & & & & $\begin{array}{l}0.055 \\
(0.13)\end{array}$ \\
\hline Meetings & & & & & $\begin{array}{c}0.021 \\
(0.0099) * *\end{array}$ & & & & \\
\hline Gatherings & & & & & & $\begin{array}{c}0.017 \\
(0.0098)^{*}\end{array}$ & & & \\
\hline Reform agitation & & & & & & & $\begin{array}{c}0.025 \\
(0.0094)^{* * *}\end{array}$ & & $\begin{array}{c}0.019 \\
(0.011)^{*}\end{array}$ \\
\hline Petitions & & & & & & & & $\begin{array}{c}0.027 \\
(0.0069) * * *\end{array}$ & $\begin{array}{c}0.023 \\
(0.013)^{*}\end{array}$ \\
\hline Net seat gain & $\begin{array}{c}0.011 \\
(0.0028) * * *\end{array}$ & $\begin{array}{c}0.0070 \\
(0.0039)^{*}\end{array}$ & $\begin{array}{c}0.0100 \\
(0.0033) * * *\end{array}$ & $\begin{array}{c}0.0098 \\
(0.0031)^{* * *}\end{array}$ & $\begin{array}{c}0.0087 \\
(0.0036)^{* *}\end{array}$ & $\begin{array}{c}0.0088 \\
(0.0032)^{* * *}\end{array}$ & $\begin{array}{c}0.0094 \\
(0.0033) * * *\end{array}$ & $\begin{array}{c}0.012 \\
(0.0029)^{* * *}\end{array}$ & $\begin{array}{c}0.0087 \\
(0.0042)^{* *}\end{array}$ \\
\hline Disenfranchised & $\begin{array}{l}-0.080 \\
(0.088)\end{array}$ & $\begin{array}{c}-0.100 \\
(0.090)\end{array}$ & $\begin{array}{l}-0.081 \\
(0.087)\end{array}$ & $\begin{array}{c}-0.078 \\
(0.089)\end{array}$ & $\begin{array}{l}-0.095 \\
(0.091)\end{array}$ & $\begin{array}{c}-0.092 \\
(0.087)\end{array}$ & $\begin{array}{l}-0.085 \\
(0.088)\end{array}$ & $\begin{array}{c}-0.039 \\
(0.090)\end{array}$ & $\begin{array}{l}-0.045 \\
(0.097)\end{array}$ \\
\hline Patron controlled & $\begin{array}{c}-0.096 \\
(0.11)\end{array}$ & $\begin{array}{l}-0.10 \\
(0.10)\end{array}$ & $\begin{array}{l}-0.10 \\
(0.10)\end{array}$ & $\begin{array}{c}-0.080 \\
(0.11)\end{array}$ & $\begin{array}{c}-0.091 \\
(0.11)\end{array}$ & $\begin{array}{l}-0.11 \\
(0.10)\end{array}$ & $\begin{array}{r}-0.097 \\
(0.10)\end{array}$ & $\begin{array}{c}-0.076 \\
(0.11)\end{array}$ & $\begin{array}{l}-0.064 \\
(0.11)\end{array}$ \\
\hline Landed interest & $\begin{array}{c}0.25 \\
(0.066)^{* * *}\end{array}$ & $\begin{array}{c}0.27 \\
(0.065)^{* * *}\end{array}$ & $\begin{array}{c}0.25 \\
(0.066)^{* * *}\end{array}$ & $\begin{array}{c}0.25 \\
(0.065)^{* * *}\end{array}$ & $\begin{array}{c}0.26 \\
(0.065)^{* * *}\end{array}$ & $\begin{array}{c}0.26 \\
(0.066)^{* * *}\end{array}$ & $\begin{array}{c}0.25 \\
(0.067)^{* * *}\end{array}$ & $\begin{array}{c}0.26 \\
(0.064)^{* * *}\end{array}$ & $\begin{array}{c}0.25 \\
(0.066)^{* * *}\end{array}$ \\
\hline $\begin{array}{l}\text { Controls } \\
\text { Observations }\end{array}$ & $\begin{array}{l}\text { YES } \\
466\end{array}$ & $\begin{array}{l}\text { YES } \\
466\end{array}$ & $\begin{array}{l}\text { YES } \\
466\end{array}$ & $\begin{array}{l}\text { YES } \\
466\end{array}$ & $\begin{array}{l}\text { YES } \\
466\end{array}$ & $\begin{array}{l}\text { YES } \\
466\end{array}$ & $\begin{array}{l}\text { YES } \\
466\end{array}$ & $\begin{array}{l}\text { YES } \\
466\end{array}$ & $\begin{array}{l}\text { YES } \\
466\end{array}$ \\
\hline
\end{tabular}

* = Significant at the 10 percent level.

** = Significant at the 5 percent level.

$* * *$ = Significant at the 1 percent level.

Note: Probit estimates. Marginal effects evaluated at the mean of the explanatory variables. Constant not shown. Standard errors in parentheses are clustered at the county level. Sample restricted to the English MPs who were present in the House of Commons on 22 March 1831. Peaceful protest is sum of Meetings and Gatherings. Violent unrest is the sum of rural violent and urban violent. Controls included are Whig/radical, Local newspapers, Emp. Herfindahl index, Population density and Army career. When tested down by a general-to-specific algorithm, petitions is significant at the 1 percent level and reform agitation is significant at the 5 percent level in col. (9). 
TABLE 8

COUNTERFACTUAL ANALYSIS OF THE LEVELS OF PROTEST AND CONSTITUENCIES' CHARACTERISTICS ON THE MPS' VOTES

\begin{tabular}{|c|c|c|c|c|c|c|c|c|c|c|}
\hline \multirow[b]{2}{*}{$\begin{array}{l}\text { Distribution } \\
\text { of events }\end{array}$} & \multicolumn{2}{|c|}{ Urban violent } & \multicolumn{2}{|c|}{ Reform Agitation } & \multicolumn{2}{|c|}{ Petitions } & \multicolumn{2}{|c|}{ Net seat gain } & \multicolumn{2}{|c|}{ Landed interest } \\
\hline & $\begin{array}{l}\text { Predicted } \\
\text { Reform } \\
\text { Support }\end{array}$ & $\begin{array}{c}\text { Predicted } \\
\text { Reform Support } \\
\text { of English MPs }\end{array}$ & $\begin{array}{l}\text { Predicted } \\
\text { Reform } \\
\text { Support }\end{array}$ & $\begin{array}{c}\text { Predicted } \\
\text { Reform Support } \\
\text { of English MPs }\end{array}$ & $\begin{array}{l}\text { Predicted } \\
\text { Reform } \\
\text { Support }\end{array}$ & $\begin{array}{c}\text { Predicted } \\
\text { Reform Support } \\
\text { of English MPs }\end{array}$ & $\begin{array}{l}\text { Predicted } \\
\text { Reform } \\
\text { Support }\end{array}$ & $\begin{array}{c}\text { Predicted } \\
\text { Reform Support } \\
\text { of English MPs }\end{array}$ & $\begin{array}{l}\text { Predicted } \\
\text { Reform } \\
\text { Support }\end{array}$ & $\begin{array}{c}\text { Predicted } \\
\text { Reform Support } \\
\text { of English MPs }\end{array}$ \\
\hline \multirow[t]{2}{*}{$1 \mathrm{st}$} & $47.68 \%$ & 222 & $48.14 \%$ & 224 & $45.61 \%$ & 213 & $42.78 \%$ & 199 & $47.08 \%$ & 219 \\
\hline & {$[0.015]$} & $\{208 ; 236\}$ & {$[0.014]$} & $\{211 ; 238\}$ & {$[0.017]$} & $\{197 ; 228\}$ & {$[0.032]$} & $\{170 ; 228\}$ & {$[0.014]$} & $\{207 ; 232\}$ \\
\hline \multirow[t]{2}{*}{ 10th } & $47.68 \%$ & 222 & $48.14 \%$ & 224 & $47.50 \%$ & 221 & $45.65 \%$ & 213 & $47.08 \%$ & 219 \\
\hline & {$[0.015]$} & $\{209 ; 236\}$ & {$[0.014]$} & $\{211 ; 238\}$ & {$[0.014]$} & $\{208 ; 234\}$ & {$[0.020]$} & $\{195 ; 231\}$ & {$[0.014]$} & $\{207 ; 232\}$ \\
\hline \multirow[t]{2}{*}{25 th } & $47.70 \%$ & 222 & $48.15 \%$ & 224 & $47.50 \%$ & 221 & $47.90 \%$ & 223 & $47.08 \%$ & 219 \\
\hline & {$[0.015]$} & $\{209 ; 236\}$ & {$[0.014]$} & $\{211 ; 238\}$ & {$[0.014]$} & $\{208 ; 234\}$ & {$[0.013]$} & $\{211 ; 235\}$ & {$[0.014]$} & $\{207 ; 232\}$ \\
\hline \multirow[t]{2}{*}{50 th } & $47.75 \%$ & 223 & $48.38 \%$ & 225 & $48.47 \%$ & 226 & $49.48 \%$ & 231 & $47.08 \%$ & 219 \\
\hline & {$[0.015]$} & $\{209 ; 236\}$ & {$[0.014]$} & $\{212 ; 238\}$ & {$[0.014]$} & $\{213 ; 239\}$ & {$[0.013]$} & $\{218 ; 243\}$ & {$[0.014]$} & $\{207 ; 232\}$ \\
\hline \multirow[t]{2}{*}{ 75th } & $49.81 \%$ & 232 & $48.62 \%$ & 227 & $49.47 \%$ & 231 & $50.29 \%$ & 234 & $47.08 \%$ & 219 \\
\hline & {$[0.013]$} & $\{220 ; 244\}$ & {$[0.014]$} & $\{214 ; 239\}$ & {$[0.014]$} & $\{218 ; 243\}$ & {$[0.015]$} & $\{220 ; 248\}$ & {$[0.014]$} & $\{207 ; 232\}$ \\
\hline \multirow[t]{2}{*}{ 90th } & $51.30 \%$ & 239 & $48.91 \%$ & 228 & $50.50 \%$ & 235 & $51.12 \%$ & 238 & $59.03 \%$ & 275 \\
\hline & [0.014] & $\{226 ; 252\}$ & {$[0.014]$} & $\{215 ; 241\}$ & {$[0.015]$} & $\{222 ; 249\}$ & {$[0.018]$} & $\{222 ; 255\}$ & {$[0.032]$} & $\{246 ; 304\}$ \\
\hline \multirow[t]{2}{*}{ 99th } & $82.16 \%$ & 383 & $65.03 \%$ & 303 & $54.89 \%$ & 256 & $53.14 \%$ & 248 & $59.03 \%$ & 275 \\
\hline & {$[0.103]$} & $\{288 ; 477\}$ & {$[0.070]$} & $\{240 ; 367\}$ & [0.024] & $\{234 ; 278\}$ & {$[0.028]$} & $\{222 ; 273\}$ & {$[0.032]$} & $\{246 ; 304\}$ \\
\hline
\end{tabular}

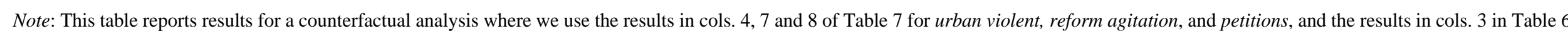

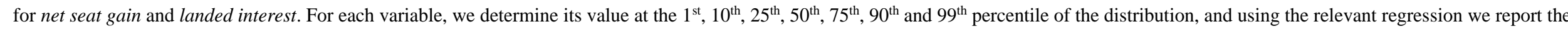
predicted probability that the 466 MPs would have voted for reform (with 95 percent confidence intervals in curly brackets). Standard errors for the predicted values are reported in square brackets. 
TABLE 9

ABSENCE FROM THE HOUSE OF COMMONS, 22 MARCH 1831

\begin{tabular}{|c|c|c|c|c|c|c|}
\hline Borough & County & MP & Affiliation & Occupation & Reason for absence & $\begin{array}{l}\text { Prob reform } \\
\text { support }\end{array}$ \\
\hline Brackley & Northamptonshire & $\begin{array}{l}\text { Robert Haldane } \\
\text { Bradshaw }\end{array}$ & Tory & Industrialist & $\begin{array}{l}\text { On } 22 \text { November 1830, he was granted a month's leave because } \\
\text { of ill health and was given another month on } 10 \text { February } 1831 .\end{array}$ & 0.08 \\
\hline Brackley & Northamptonshire & James Bradshaw & Tory & $\begin{array}{l}\text { Army } \\
\text { Officer }\end{array}$ & $\begin{array}{l}\text { His father was ill (see above) and without any additional } \\
\text { information, we speculate that he remained with him during this } \\
\text { illness. }\end{array}$ & 0.03 \\
\hline Derbyshire & Derbyshire & $\begin{array}{l}\text { George Augustus } \\
\text { Henry Cavendish }\end{array}$ & Whig & Landowner & He was apparently too ill to attend the House on 22 March 1831. & 0.99 \\
\hline Dunwich & Suffolk & Frederick Barne & Tory & $\begin{array}{l}\text { Army } \\
\text { Officer }\end{array}$ & $\begin{array}{l}\text { On } 10 \text { February } 1831 \text {, he received a month's leave of absence on } \\
\text { account of ill health and remained absent on } 22 \text { March } 1831 \text {, even } \\
\text { though the reform bill proposed Dunwich's disfranchisement. }\end{array}$ & 0.21 \\
\hline Helstone & Cornwall & $\begin{array}{l}\text { Samuel John Brooke } \\
\text { Pechell }\end{array}$ & Whig & $\begin{array}{l}\text { Army } \\
\text { Officer }\end{array}$ & $\begin{array}{l}\text { On March } 7^{\text {th }}, 1831 \text {, he was excused from attending the Durham } \\
\text { election committee because of illness and was absent from the } \\
\text { division on the second reading of the ministry's reform bill } 15 \\
\text { days later. }\end{array}$ & 0.91 \\
\hline Launceston & Cornwall & $\begin{array}{l}\text { James Willoughby } \\
\text { Gordon }\end{array}$ & Tory & $\begin{array}{l}\text { Army } \\
\text { Officer }\end{array}$ & $\begin{array}{l}\text { In March } 1831 \text {, he informed his patron, Northumberland, who } \\
\text { wished him to oppose the government's reform bill, that it was } \\
\text { 'quite impossible for me as the senior officer upon the King's staff } \\
\text { to vote against His Majesty's government under any circumstances } \\
\text { whatever', and that he could only promise to 'keep away from the } \\
\text { discussion'. He was absent from the vote on } 22 \text { March } 1831 \text {, was } \\
\text { then given 'notice to quit' and he eventually resigned his seat on } 5 \\
\text { April } 1831 \text {. }\end{array}$ & 0.02 \\
\hline Midhurst & Sussex & George Smith & Whig & Banker & $\begin{array}{l}\text { On } 22 \text { March } 1831 \text {, he was ill but he made it known that he would } \\
\text { have voted for it if present. }\end{array}$ & 0.97 \\
\hline Newton & Lancashire & Thomas Legh & Tory & Landowner & $\begin{array}{l}\text { On } 14 \text { February } 1831 \text {, he was granted three weeks' leave, } \\
\text { following his wife's death, and on } 9 \text { March } 1831 \text {, another fortnight } \\
\text { because of illness in his family. He did not vote on the second } \\
\text { reading of the Grey ministry's reform bill, which proposed } \\
\text { Newton's disfranchisement. }\end{array}$ & 0.30 \\
\hline
\end{tabular}




\begin{tabular}{|c|c|c|c|c|c|c|}
\hline Newtown & Hampshire & Hudson Gurney & Whig & Banker & $\begin{array}{l}\text { He was plagued by a cold and did not vote. He, however, indicated } \\
\text { two days later in a debate that he had actually voted in favor of the } \\
\text { bill. }\end{array}$ & 0.90 \\
\hline Pontefract & Yorkshire & Culling Eardley Smith & Whig & Landowner & $\begin{array}{l}\text { On } 7 \text { March 1831, after serving on an election committee, he was } \\
\text { granted a month's leave to attend to private business. }\end{array}$ & 0.18 \\
\hline Sudbury & Suffolk & Bethell Walrond & Tory & $\begin{array}{l}\text { Army } \\
\text { Officer }\end{array}$ & $\begin{array}{l}\text { On } 16 \text { March 1831, he was granted a ten-day leave to attend the } \\
\text { assizes. }\end{array}$ & 0.87 \\
\hline Sussex & Sussex & Walter Burrell & Whig & Landowner & $\begin{array}{l}\text { On } 14 \text { March 1831, after serving on an election committee, he was } \\
\text { granted a two-week leave to attend to private business. }\end{array}$ & 0.38 \\
\hline Tamworth & Staffordshire & $\begin{array}{l}\text { Charles Vere Ferrars } \\
\text { Compton Townshend }\end{array}$ & Tory & Landowner & $\begin{array}{l}\text { No reason given as to his absence from the division on the second } \\
\text { reading of the Grey ministry's reform bill on } 22 \text { March } 1831 \text {. }\end{array}$ & 0.98 \\
\hline Thirsk & Yorkshire & Robert Frankland & Whig & Landowner & $\begin{array}{l}\text { No reason given as to his absence from the division on the second } \\
\text { reading of the Grey ministry's reform bill on } 22 \text { March } 1831 \text {. }\end{array}$ & 0.99 \\
\hline Weobly & Herefordshire & Edward Thynne & Tory & $\begin{array}{l}\text { Army } \\
\text { Officer }\end{array}$ & $\begin{array}{l}\text { An army officer on active service, he was returned in abstentia, } \\
\text { rarely attended Parliament and let his younger brother Edward sit } \\
\text { for the borough in April } 1831 \text {. }\end{array}$ & 0.05 \\
\hline Wilton & Wiltshire & $\begin{array}{l}\text { William Henry Lytton } \\
\text { Earle Bulwer }\end{array}$ & Whig & $\begin{array}{l}\text { Army } \\
\text { Officer }\end{array}$ & $\begin{array}{l}\text { Bulwer was a Whig beholden to the Tory patron of Wilton, which } \\
\text { was scheduled to lose a Member because of the reform. This may } \\
\text { have led him not to vote on the second reading of the bill on } 22 \\
\text { March } 1831 \text {, after rumors began to circulate on } 5 \text { March that he } \\
\text { had joined the ranks of the Tory opposition. }\end{array}$ & 0.02 \\
\hline Winchelsea & Sussex & John Williams & Whig & Lawyer & On 22 March 1831, he was working on the legal circuit. & 0.93 \\
\hline Yarmouth & Norfolk & $\begin{array}{l}\text { Charles Edmund } \\
\text { Rumbold }\end{array}$ & Whig & $\begin{array}{l}\text { Army } \\
\text { Officer }\end{array}$ & $\begin{array}{l}\text { On } 14 \text { March } 1831 \text {, he was excused because of illness, which also } \\
\text { prevented him from voting on } 22 \text { March } 1831 \text {. }\end{array}$ & 0.94 \\
\hline
\end{tabular}

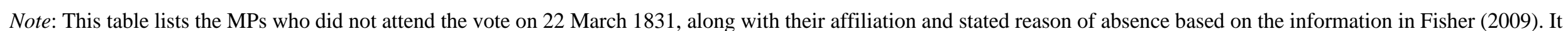

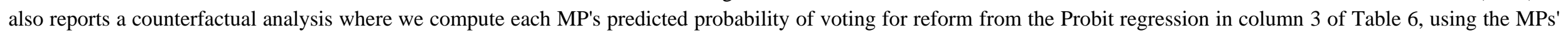
observable characteristics and those of their constituencies. Table A7 in the online appendix reports the reason why the four vacant seats were vacant. 
TABLE 10

THE OCCUPATIONS OF THE MPS: MEAN COMPARISON TESTS OF THE PROPORTION OF MPS VOTING YES AND NO

\begin{tabular}{|c|c|c|c|}
\hline & No vote & Yes vote & t-test \\
\hline & mean $\%$ & mean $\%$ & p-value \\
\hline Army career & 20.1 & 15.7 & 0.08 \\
\hline Financier & 5.0 & 6.1 & 0.31 \\
\hline Industrialist & 3.4 & 7.0 & 0.04 \\
\hline Jurist & 15.6 & 9.1 & 0.02 \\
\hline Merchant & 8.4 & 10.0 & 0.28 \\
\hline Landowner & 42.1 & 49.0 & 0.08 \\
\hline
\end{tabular}

Note: The table reports the results of one-sided t-tests for mean differences in the percentage of MPs within different occupational and landownership categories. The p-values are for the test of the larger mean being bigger than the smaller. The sample includes the 466 English who voted. Each MP can belong to more than one category. 
TABLE 11

THE EFFECT OF PROTEST AND POLITICAL EXPEDIENCE ON THE SHARE OF WHIGS AND RADICALS ELECTED IN THE 1830 GENERAL ELECTION: OLS ESTIMATES

\begin{tabular}{|c|c|c|c|c|}
\hline \multirow[t]{2}{*}{ Dependent variable } & \multicolumn{4}{|c|}{ Whig share in 1830} \\
\hline & (1) & (2) & (3) & (4) \\
\hline All protest ${ }^{\mathrm{a}}$ & $\begin{array}{c}0.29 \\
{[0.38]}\end{array}$ & & & \\
\hline Violent unrest $^{\mathrm{a}}$ & & $\begin{array}{c}8.12 \\
{[7.29]}\end{array}$ & & \\
\hline Peaceful protest ${ }^{\mathrm{a}}$ & & & $\begin{array}{c}0.28 \\
{[0.39]}\end{array}$ & \\
\hline Petitions $^{\mathrm{b}}$ & & & & $\begin{array}{c}0.54 \\
{[0.85]}\end{array}$ \\
\hline Net seat gain & $\begin{array}{l}0.019 \\
{[0.10]}\end{array}$ & $\begin{array}{c}-0.0075 \\
{[0.11]}\end{array}$ & $\begin{array}{l}0.022 \\
{[0.10]}\end{array}$ & $\begin{array}{c}0.057 \\
{[0.095]}\end{array}$ \\
\hline Local newspapers & $\begin{array}{c}-0.019 \\
{[0.011]^{*}}\end{array}$ & $\begin{array}{c}-0.023 \\
{[0.011]^{* *}}\end{array}$ & $\begin{array}{c}-0.019 \\
{[0.011]^{*}}\end{array}$ & $\begin{array}{l}-0.022 \\
{[0.015]}\end{array}$ \\
\hline Whig share in 1826 & $\begin{array}{c}0.67 \\
{[0.046]^{* * *}}\end{array}$ & $\begin{array}{c}0.67 \\
{[0.045]^{* * *}}\end{array}$ & $\begin{array}{c}0.67 \\
{[0.046]^{* * *}}\end{array}$ & $\begin{array}{c}0.67 \\
{[0.045]^{* * *}}\end{array}$ \\
\hline Landed interest & $\begin{array}{c}8.56 \\
{[4.77]^{*}}\end{array}$ & $\begin{array}{c}8.43 \\
{[4.76]^{*}}\end{array}$ & $\begin{array}{c}8.56 \\
{[4.77]^{*}}\end{array}$ & $\begin{array}{c}8.39 \\
{[4.71]^{*}}\end{array}$ \\
\hline Disenfranchised & $\begin{array}{l}-8.28 \\
{[5.90]}\end{array}$ & $\begin{array}{l}-8.21 \\
{[5.92]}\end{array}$ & $\begin{array}{l}-8.27 \\
{[5.89]}\end{array}$ & $\begin{array}{l}-7.43 \\
{[6.53]}\end{array}$ \\
\hline Patron controlled & $\begin{array}{c}-8.08 \\
{[3.46]^{* *}}\end{array}$ & $\begin{array}{c}-7.91 \\
{[3.48]^{* *}}\end{array}$ & $\begin{array}{c}-8.11 \\
{[3.45]^{* *}}\end{array}$ & $\begin{array}{c}-7.87 \\
{[3.37]^{* *}}\end{array}$ \\
\hline Emp. Herfindahl index & $\begin{array}{l}-12.5 \\
{[25.4]}\end{array}$ & $\begin{array}{l}-11.1 \\
{[26.5]}\end{array}$ & $\begin{array}{l}-12.6 \\
{[25.4]}\end{array}$ & $\begin{array}{l}-10.9 \\
{[25.0]}\end{array}$ \\
\hline Population density & $\begin{array}{c}0.22 \\
{[1.79]}\end{array}$ & $\begin{array}{c}0.57 \\
{[1.68]}\end{array}$ & $\begin{array}{c}0.23 \\
{[1.80]}\end{array}$ & $\begin{array}{c}0.20 \\
{[1.76]}\end{array}$ \\
\hline $\begin{array}{l}\text { Adjusted R-squared } \\
\text { Observations }\end{array}$ & $\begin{array}{l}0.55 \\
244\end{array}$ & $\begin{array}{l}0.55 \\
244\end{array}$ & $\begin{array}{l}0.55 \\
244\end{array}$ & $\begin{array}{l}0.55 \\
244\end{array}$ \\
\hline
\end{tabular}

* = Significant at the 10 percent level.

** = Significant at the 5 percent level.

$* * *=$ Significant at the 1 percent level.

Note: Linear regressions estimated with OLS. Constant not reported. Standard errors in parentheses are clustered at the county level. Sample restricted to the 244 English constituencies. a. the variables are recoded and accumulate protest events before 29 July 1830 . b. all but ten petitions were submitted after the 1830 election. Descriptive statistics are reported in Table A12 in the online appendix. 
TABLE 12

FALSIFICATION TEST. THE EFFECT OF PROTEST IN 1828-31 ON ROLL CALL VOTES RELATED TO THE FAILED REFORM BILLS OF 1810 AND 1822: PROBIT ESTIMATES

\begin{tabular}{|c|c|c|c|c|c|c|}
\hline \multirow[t]{2}{*}{ Dependent variable } & \multicolumn{3}{|c|}{ Yes vote 1810} & \multicolumn{3}{|c|}{ Yes vote 1822} \\
\hline & (1) & (2) & (3) & (4) & (5) & (6) \\
\hline Violent unrest & $\begin{array}{c}0.013 \\
(0.031)\end{array}$ & & & $\begin{array}{l}-0.045 \\
(0.059)\end{array}$ & & \\
\hline Peaceful protest & & $\begin{array}{l}-0.0038 \\
(0.0027)\end{array}$ & & & $\begin{array}{l}-0.0053 \\
(0.0035)\end{array}$ & \\
\hline Petitions & & & $\begin{array}{c}0.0052 \\
(0.0061)\end{array}$ & & & $\begin{array}{c}-0.0080 \\
(0.011)\end{array}$ \\
\hline Net seat gain & $\begin{array}{c}0.0028 \\
(0.0014)^{* *}\end{array}$ & $\begin{array}{c}0.0035 \\
(0.0017)^{* *}\end{array}$ & $\begin{array}{c}0.0029 \\
(0.0014)^{* *}\end{array}$ & $\begin{array}{c}0.0060 \\
(0.0018) * * *\end{array}$ & $\begin{array}{c}0.0071 \\
(0.0019)^{* * *}\end{array}$ & $\begin{array}{c}0.0058 \\
(0.0018)^{* * *}\end{array}$ \\
\hline Disenfranchised & $\begin{array}{l}-0.023 \\
(0.035)\end{array}$ & $\begin{array}{c}-0.021 \\
(0.034)\end{array}$ & $\begin{array}{l}-0.014 \\
(0.039)\end{array}$ & $\begin{array}{l}-0.018 \\
(0.087)\end{array}$ & $\begin{array}{l}-0.012 \\
(0.088)\end{array}$ & $\begin{array}{l}-0.030 \\
(0.087)\end{array}$ \\
\hline Uncontested elections & $\begin{array}{c}-0.050 \\
(0.027)^{*}\end{array}$ & $\begin{array}{c}-0.051 \\
(0.026)^{*}\end{array}$ & $\begin{array}{c}-0.048 \\
(0.026)^{*}\end{array}$ & $\begin{array}{c}0.069 \\
(0.061)\end{array}$ & $\begin{array}{c}0.069 \\
(0.063)\end{array}$ & $\begin{array}{c}0.061 \\
(0.061)\end{array}$ \\
\hline Landed interest & $\begin{array}{c}0.036 \\
(0.047)\end{array}$ & $\begin{array}{c}0.029 \\
(0.046)\end{array}$ & $\begin{array}{c}0.039 \\
(0.048)\end{array}$ & $\begin{array}{c}0.092 \\
(0.060)\end{array}$ & $\begin{array}{c}0.089 \\
(0.060)\end{array}$ & $\begin{array}{c}0.090 \\
(0.060)\end{array}$ \\
\hline Whig/Radical & $\begin{array}{c}0.33 \\
(0.044)^{* * *}\end{array}$ & $\begin{array}{c}0.33 \\
(0.042)^{* * *}\end{array}$ & $\begin{array}{c}0.32 \\
(0.043)^{* * *}\end{array}$ & $\begin{array}{c}0.57 \\
(0.042)^{* * * *}\end{array}$ & $\begin{array}{c}0.57 \\
(0.042)^{* * * *}\end{array}$ & $\begin{array}{c}0.57 \\
(0.042)^{* * * *}\end{array}$ \\
\hline Local newspapers & $\begin{array}{c}0.00015 \\
(0.00015)\end{array}$ & $\begin{array}{c}0.00029 \\
(0.00014)^{* *}\end{array}$ & $\begin{array}{c}0.00011 \\
(0.00018)\end{array}$ & $\begin{array}{c}0.00030 \\
(0.00019)\end{array}$ & $\begin{array}{c}0.00021 \\
(0.00028)\end{array}$ & $\begin{array}{c}0.00025 \\
(0.00026)\end{array}$ \\
\hline Emp. Herf. Index & $\begin{array}{l}0.066 \\
(0.14)\end{array}$ & $\begin{array}{l}0.055 \\
(0.13)\end{array}$ & $\begin{array}{l}0.078 \\
(0.14)\end{array}$ & $\begin{array}{l}-0.18 \\
(0.14)\end{array}$ & $\begin{array}{l}-0.20 \\
(0.14)\end{array}$ & $\begin{array}{l}-0.20 \\
(0.14)\end{array}$ \\
\hline Population density & $\begin{array}{l}0.0059 \\
(0.014)\end{array}$ & $\begin{array}{l}0.0082 \\
(0.013)\end{array}$ & $\begin{array}{l}0.0050 \\
(0.014)\end{array}$ & $\begin{array}{l}-0.020 \\
(0.022)\end{array}$ & $\begin{array}{c}-0.015 \\
(0.021)\end{array}$ & $\begin{array}{l}-0.017 \\
(0.023)\end{array}$ \\
\hline Observations & 486 & 486 & 486 & 487 & 487 & 487 \\
\hline
\end{tabular}

* = Significant at the 10 percent level.

** = Significant at the 5 percent level.

*** = Significant at the 1 percent level.

Note: Probit estimator. Marginal effects evaluated at the mean of the explanatory variables. Constants not reported. Standard errors in parentheses are clustered at the county level. Sample restricted to the English MPs. Uncontested elections refers to the seven previous elections; Emp. Herf. index and population density refer to the nearest census year. Only yes votes recorded. MPs who did not vote are assumed to vote no. Descriptive statistics reported in Table A13 in the online appendix. 


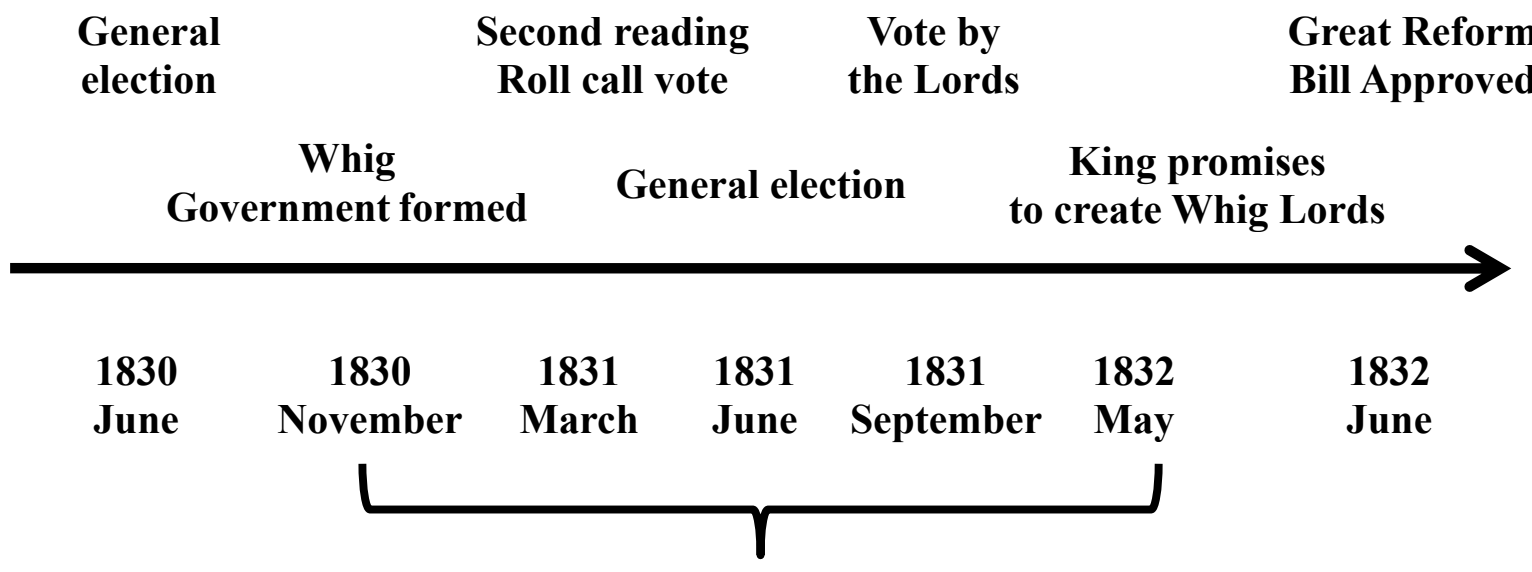

The hurdles

Figure 1: The timeline of the main events as the bill passes through the political process.

Source: Brock (1973) and Cannon (1973) 


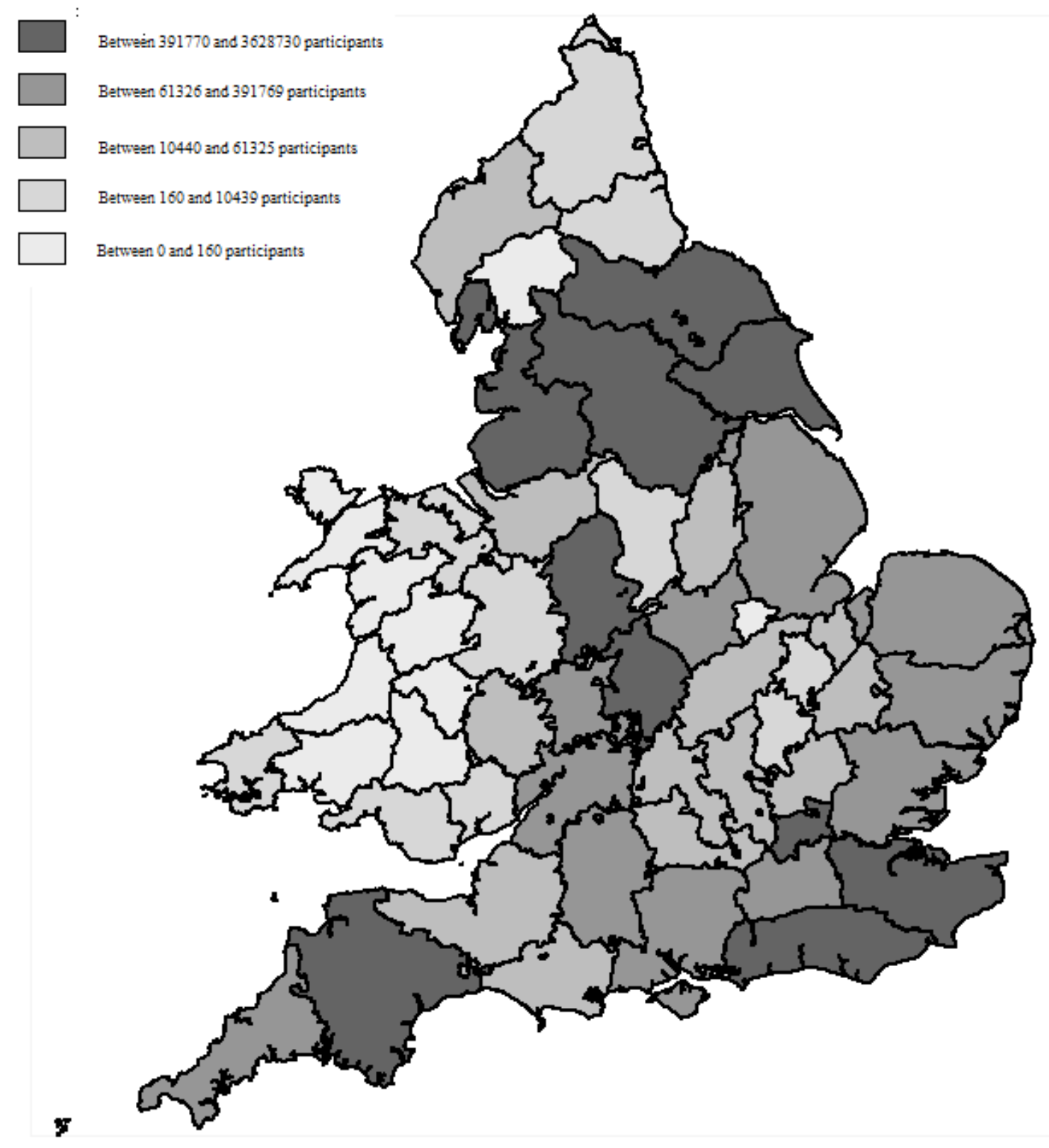

Figure 2a. All Protest. 


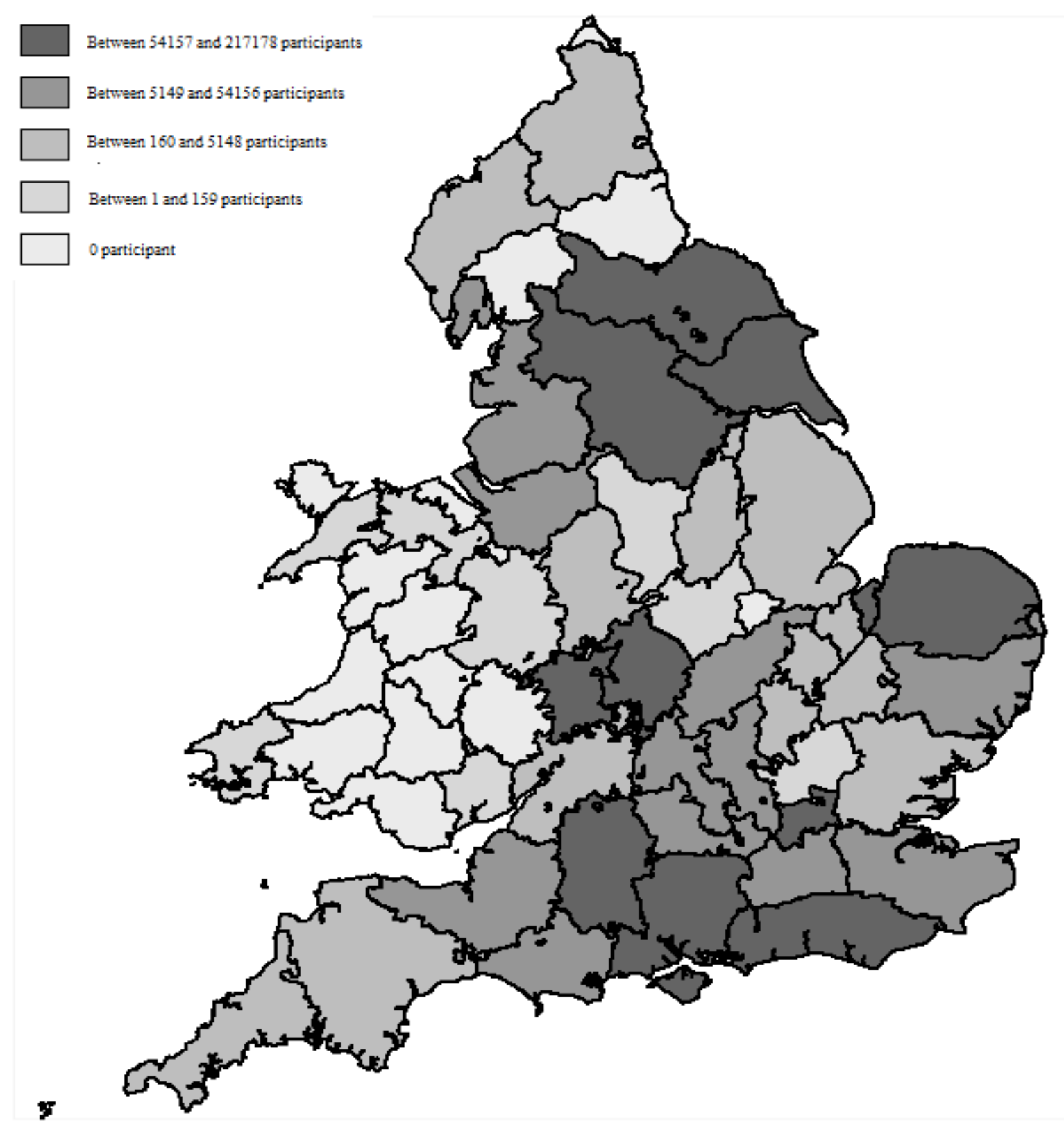

Figure 2b. Violent Protest 


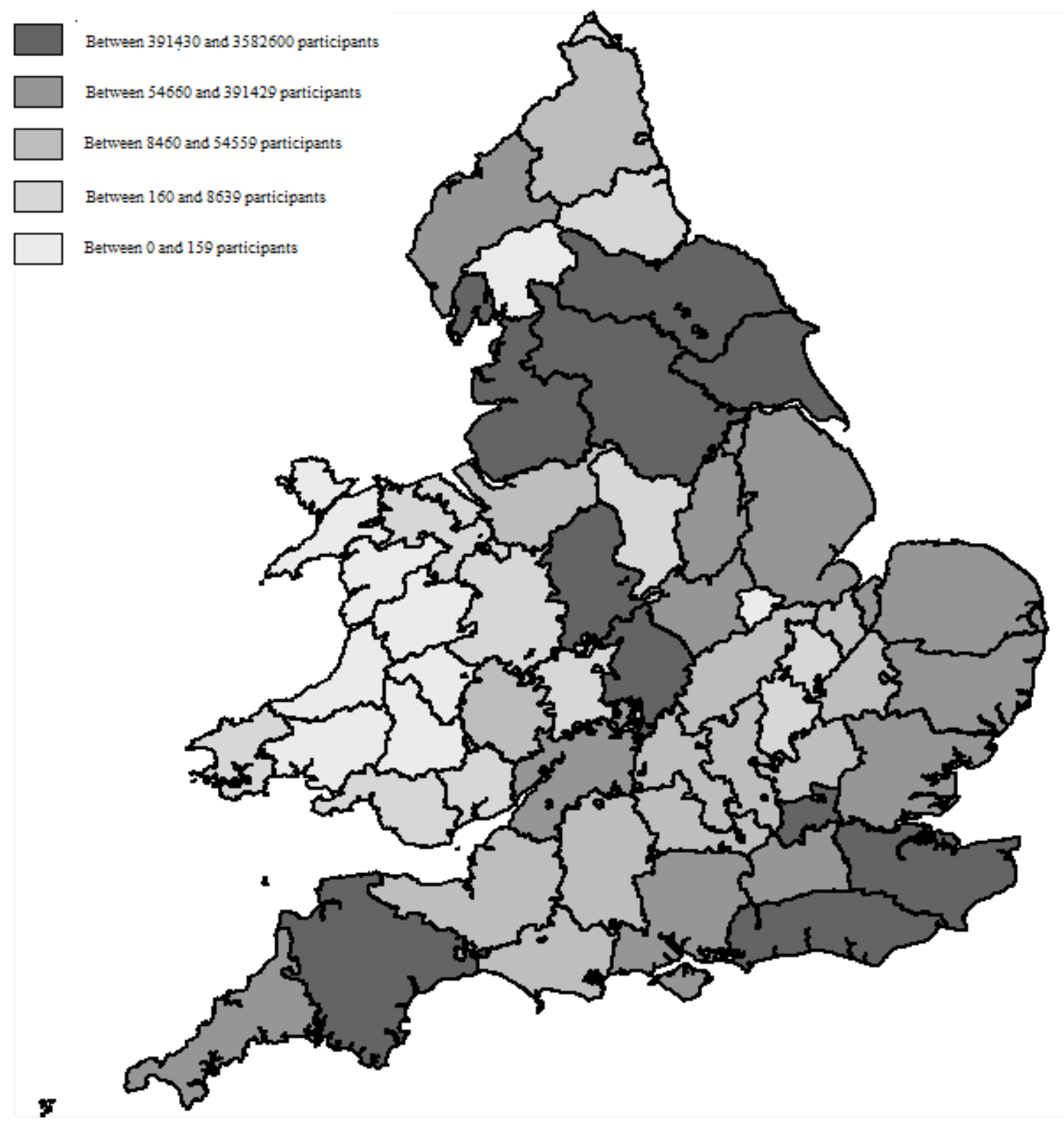

Figure 2c. Peaceful Protest

FIGURE 2

PUBLIC PROTEST IN ENGLISH AND WELSH COUNTIES BY NUMBER OF PARTICIPANTS, 1 JANUARY 1828 - 22 MARCH 1831.

Source: Horn and Tilly (1988). 


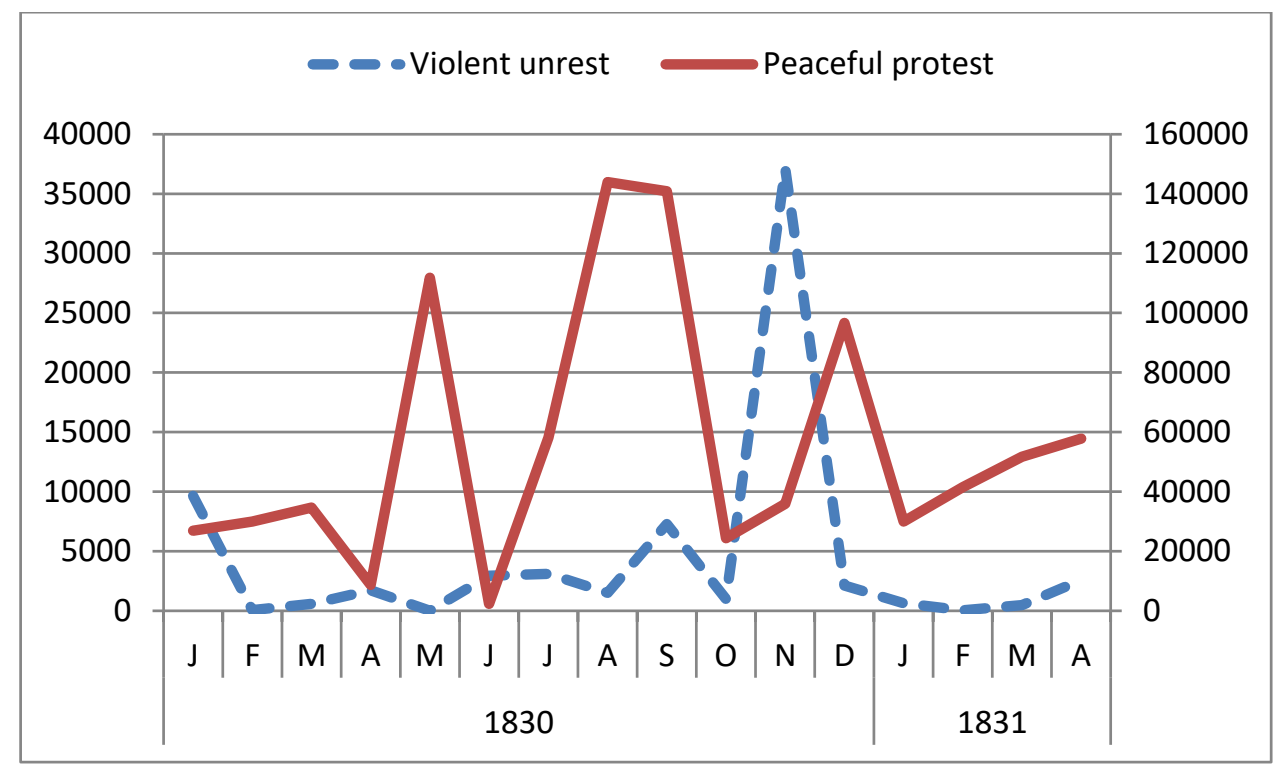

FIGURE 3

VIOLENT UNREST AND PEACEFUL PROTEST, 1830-1831

Note: These figures display the number of monthly protests in England and Wales between January 1830 and April 1831. The solid line, measured on the right-hand y-axis graphs participation in peaceful protest (meetings and gatherings) while the dotted line, measured on the left-hand y-axis graphs participation in violent urban and rural unrest.

Source: Horn and Tilly (1988). 


\section{Online Appendix}

\section{What Motivates an OligarChic Elite To DeMOCRATIZE? EVIDENCE FROM THE ROLL}

\section{CALl Vote on the Great ReForm ACT OF 1832}

\section{TOKE S. AIDT AND RAPHAËL FRANCK}

In this appendix, we provide some supplementary evidence in support of our interpretation of the econometric results reported in the main text, additional information about how we coded the variable related to newspaper circulation, historical evidence on the three hypothesizes, and a list of the definitions and sources of all the variables we use in the analysis.

The additional evidence includes the following. First, we show that our results are robust to using alternative definitions of the key variables. Second, we show that the results are similar when London is excluded from the sample. Third, we show that including additional control variables does not affect our results. We also show that the personal circumstances of the MPs (their age, occupation, education, and so on) cannot explain their vote behavior. Fourth, we report the correlation matrix for the variables related to violent unrest and public opinion. Fifth, we present evidence from the bibliographical literature on the reasons why the 18 absent English MPs were not present for the vote and a counterfactual analysis on their predicted vote had they been present based on observables. Finally, we report probit IV estimates of the effect of protest on the MPs' votes. Descriptive statistics for the new variables used in the appendix are reported in Tables A11 to A14.

\section{A1. Alternative definitions of the key variables}

Tables A1 and A2 show that the main results are robust to three alternative definitions of the variable capturing public protest: these are the number of protest events (rather than the number of participants), participants per capita and per adult male. Table A1 shows that the results for all protest are robust to these permutations, to an alternative measure of net seat gain which computes the gain in percentage rather than as the absolute value, and to normalizing 
newspaper circulation by population. Table A2 reproduces Table 6 with the public protest variables defined as the number of events rather than as the number of participants.

Table A1: Robustness checks. The effect of protest on a MP's vote in favor of the reform bill: Probit estimates under alternative definitions of key variables

\begin{tabular}{|c|c|c|c|c|c|}
\hline \multirow[t]{2}{*}{ Dependent variable } & \multicolumn{5}{|c|}{ Yes vote } \\
\hline & $(1)$ & $(2)$ & $(3)$ & $(4)$ & $(5)$ \\
\hline All protest (\#events) ${ }^{\mathrm{a}}$ & $\begin{array}{c}0.072 \\
(0.023)^{* * *}\end{array}$ & & & & \\
\hline All protest (par. per capita) ${ }^{b}$ & & $\begin{array}{c}0.47 \\
(0.16)^{* * *}\end{array}$ & & & \\
\hline All protest (par. per adult male) ${ }^{\mathrm{b}}$ & & & $\begin{array}{c}0.14 \\
(0.045)^{* * *}\end{array}$ & $\begin{array}{c}0.13 \\
(0.043)^{* * *}\end{array}$ & $\begin{array}{c}0.23 \\
(0.054)^{* * *}\end{array}$ \\
\hline Net seat gain & $\begin{array}{c}0.010 \\
(0.0031)^{* * *}\end{array}$ & $\begin{array}{c}0.011 \\
(0.0028)^{* * *}\end{array}$ & $\begin{array}{c}0.011 \\
(0.0028)^{* * *}\end{array}$ & & $\begin{array}{c}0.011 \\
(0.0027)^{* * * *}\end{array}$ \\
\hline Net seat gain $(\%)$ & & & & $\begin{array}{c}0.0022 \\
(0.0010)^{* *}\end{array}$ & \\
\hline Disenfranchised & $\begin{array}{l}-0.086 \\
(0.089)\end{array}$ & $\begin{array}{l}-0.074 \\
(0.088)\end{array}$ & $\begin{array}{l}-0.075 \\
(0.088)\end{array}$ & $\begin{array}{l}-0.089 \\
(0.088)\end{array}$ & $\begin{array}{l}-0.079 \\
(0.089)\end{array}$ \\
\hline Patron controlled & $\begin{array}{l}-0.095 \\
(0.10)\end{array}$ & $\begin{array}{l}-0.077 \\
(0.11)\end{array}$ & $\begin{array}{l}-0.076 \\
(0.11)\end{array}$ & $\begin{array}{l}-0.077 \\
(0.11)\end{array}$ & $\begin{array}{l}-0.080 \\
(0.11)\end{array}$ \\
\hline Landed interest & $\begin{array}{c}0.26 \\
(0.065)^{* * * *}\end{array}$ & $\begin{array}{c}0.26 \\
(0.065)^{* * * *}\end{array}$ & $\begin{array}{c}0.27 \\
(0.065)^{* * *}\end{array}$ & $\begin{array}{c}0.26 \\
(0.065)^{* * * *}\end{array}$ & $\begin{array}{c}0.27 \\
(0.066)^{* * *}\end{array}$ \\
\hline Whig/radical & $\begin{array}{c}0.84 \\
(0.031)^{* * *}\end{array}$ & $\begin{array}{c}0.84 \\
(0.030)^{* * *}\end{array}$ & $\begin{array}{c}0.84 \\
(0.030)^{* * *}\end{array}$ & $\begin{array}{c}0.84 \\
(0.031)^{* * * *}\end{array}$ & $\begin{array}{c}0.85 \\
(0.030)^{* * * *}\end{array}$ \\
\hline Local newspapers & $\begin{array}{c}-0.00070 \\
(0.00022)^{* * *}\end{array}$ & $\begin{array}{c}-0.00072 \\
(0.00039)^{*}\end{array}$ & $\begin{array}{c}-0.00072 \\
(0.00039)^{*}\end{array}$ & $\begin{array}{l}-0.00060 \\
(0.00041)\end{array}$ & \\
\hline Local newspapers per capita & & & & & $\begin{array}{c}-0.0041 \\
(0.0014)^{* * *}\end{array}$ \\
\hline Emp. Herfindahl index & $\begin{array}{c}-1.19 \\
(0.50)^{* *}\end{array}$ & $\begin{array}{c}-1.21 \\
(0.51)^{* *}\end{array}$ & $\begin{array}{c}-1.20 \\
(0.51)^{* *}\end{array}$ & $\begin{array}{c}-1.22 \\
(0.51)^{* *}\end{array}$ & $\begin{array}{c}-1.19 \\
(0.52)^{* *}\end{array}$ \\
\hline Population density & $\begin{array}{l}-0.011 \\
(0.041)\end{array}$ & $\begin{array}{l}-0.016 \\
(0.038)\end{array}$ & $\begin{array}{l}-0.019 \\
(0.038)\end{array}$ & $\begin{array}{l}-0.023 \\
(0.040)\end{array}$ & $\begin{array}{l}-0.023 \\
(0.037)\end{array}$ \\
\hline Army career & $\begin{array}{c}-0.15 \\
(0.087)^{*}\end{array}$ & $\begin{array}{c}-0.15 \\
(0.086)^{*}\end{array}$ & $\begin{array}{c}-0.15 \\
(0.087)^{*}\end{array}$ & $\begin{array}{c}-0.14 \\
(0.087)^{*}\end{array}$ & $\begin{array}{c}-0.16 \\
(0.087)^{*}\end{array}$ \\
\hline Observations & 466 & 466 & 466 & 466 & 466 \\
\hline
\end{tabular}

Note: Probit estimator. Marginal effects evaluated at the mean of the explanatory variables. Standard errors in parentheses are clustered at the county level. Sample restricted to the English MPs, present in the House of Commons on 22 March 1831 and who voted. a. all protest is the number of protest events; b. all protest is the number of participants in all protest events between 1 January 1828 and 22 March 1831. *** $\mathrm{p}<0.01$, ** $\mathrm{p}<0.05$, $* \mathrm{p}<0.1$. 
Table A2. Alternative coding of protest data and net seat gain variable. Probit estimates.

\begin{tabular}{|c|c|c|c|c|c|c|c|c|c|c|}
\hline \multirow[t]{2}{*}{ Dependent Var. } & \multicolumn{10}{|c|}{ Yes vote } \\
\hline & (1) & (2) & (3) & (4) & (5) & (6) & (7) & (8) & (9) & (10) \\
\hline All protest & & & & & & & & & & $\begin{array}{c}0.015 \\
(0.0066)^{* *}\end{array}$ \\
\hline Violent unrest (\#events) $^{\mathrm{a}}$ & $\begin{array}{c}0.19 \\
(0.14)\end{array}$ & & & & & & & & & \\
\hline Peaceful protest (\#events) ${ }^{\mathrm{a}}$ & & $\begin{array}{c}0.098 \\
(0.026)^{* * *}\end{array}$ & & & & & & & & \\
\hline Rural violent (\#events) ${ }^{\mathrm{a}}$ & & & $\begin{array}{l}-0.039 \\
(0.29)\end{array}$ & & & & & & $\begin{array}{l}-0.16 \\
(0.34)\end{array}$ & \\
\hline Urban violent (\#events) $^{\mathrm{a}}$ & & & & $\begin{array}{c}0.33 \\
(0.094)^{* * *}\end{array}$ & & & & & $\begin{array}{l}-0.28 \\
(0.34)\end{array}$ & \\
\hline Meetings (\#events) ${ }^{\mathrm{a}}$ & & & & & $\begin{array}{c}0.11 \\
(0.030)^{* * *}\end{array}$ & & & & & \\
\hline Gatherings (\#events) ${ }^{\mathrm{a}}$ & & & & & & $\begin{array}{c}0.54 \\
(0.22)^{* *}\end{array}$ & & & & \\
\hline Reform agitation (\#events) ${ }^{a}$ & & & & & & & $\begin{array}{c}0.83 \\
(0.30)^{* * *}\end{array}$ & & $\begin{array}{c}0.91 \\
(0.52)^{*}\end{array}$ & \\
\hline Petitions & & & & & & & & $\begin{array}{c}0.027 \\
(0.0069) * * *\end{array}$ & $\begin{array}{c}0.024 \\
(0.016)\end{array}$ & \\
\hline Net seat gain proposal & & & & & & & & & & $\begin{array}{c}0.011 \\
(0.0035)^{* * *}\end{array}$ \\
\hline Net seat gain & $\begin{array}{c}0.012 \\
(0.0026)^{* * *}\end{array}$ & $\begin{array}{c}0.0098 \\
(0.0033)^{* * *}\end{array}$ & $\begin{array}{c}0.011 \\
(0.0027)^{* * * *}\end{array}$ & $\begin{array}{c}0.010 \\
(0.0032)^{* * *}\end{array}$ & $\begin{array}{c}0.0097 \\
(0.0034)^{* * *}\end{array}$ & $\begin{array}{c}0.011 \\
(0.0028)^{* * * *}\end{array}$ & $\begin{array}{c}0.0094 \\
(0.0036)^{* * *}\end{array}$ & $\begin{array}{c}0.012 \\
(0.0029)^{* * *}\end{array}$ & $\begin{array}{c}0.010 \\
(0.0036)^{* * *}\end{array}$ & \\
\hline Disenfranchised & $\begin{array}{c}-0.081 \\
(0.088)\end{array}$ & $\begin{array}{l}-0.088 \\
(0.089)\end{array}$ & $\begin{array}{l}-0.082 \\
(0.087)\end{array}$ & $\begin{array}{l}-0.079 \\
(0.089)\end{array}$ & $\begin{array}{l}-0.089 \\
(0.089)\end{array}$ & $\begin{array}{c}-0.083 \\
(0.086)\end{array}$ & $\begin{array}{c}-0.096 \\
(0.089)\end{array}$ & $\begin{array}{c}-0.039 \\
(0.090)\end{array}$ & $\begin{array}{l}-0.061 \\
(0.097)\end{array}$ & $\begin{array}{l}-0.079 \\
(0.089)\end{array}$ \\
\hline Patron controlled & $\begin{array}{l}-0.099 \\
(0.11)\end{array}$ & $\begin{array}{r}-0.095 \\
(0.10)\end{array}$ & $\begin{array}{l}-0.11 \\
(0.10)\end{array}$ & $\begin{array}{l}-0.092 \\
(0.11)\end{array}$ & $\begin{array}{l}-0.095 \\
(0.10)\end{array}$ & $\begin{array}{l}-0.099 \\
(0.10)\end{array}$ & $\begin{array}{l}-0.097 \\
(0.10)\end{array}$ & $\begin{array}{l}-0.076 \\
(0.11)\end{array}$ & $\begin{array}{c}-0.080 \\
(0.11)\end{array}$ & $\begin{array}{l}-0.088 \\
(0.10)\end{array}$ \\
\hline Landed interest & $\begin{array}{c}0.26 \\
(0.066)^{* * *}\end{array}$ & $\begin{array}{c}0.26 \\
(0.065)^{* * * *}\end{array}$ & $\begin{array}{c}0.25 \\
(0.066)^{* * *}\end{array}$ & $\begin{array}{c}0.26 \\
(0.065)^{* * *}\end{array}$ & $\begin{array}{c}0.26 \\
(0.065)^{* * *}\end{array}$ & $\begin{array}{c}0.26 \\
(0.065)^{* * *}\end{array}$ & $\begin{array}{c}0.27 \\
(0.065)^{* * *}\end{array}$ & $\begin{array}{c}0.26 \\
(0.064)^{* * *}\end{array}$ & $\begin{array}{c}0.27 \\
(0.064)^{* * *}\end{array}$ & $\begin{array}{c}0.26 \\
(0.066)^{* * *}\end{array}$ \\
\hline
\end{tabular}

Note: Probit estimates. The same controls as in Table 7 are included. Each regression has 466 observations. Marginal effects evaluated at the mean of the explanatory variables. Constant not shown. Standard errors in parentheses are clustered at the county level. Sample restricted to the English MPs who were present in the House of Commons on 22 March 1831 . a. defined as the number of protest events (rather than the number of participants) Peaceful protest is sum of Meetings and Gatherings. Violent unrest is the sum of rural violent and urban violent. Controls included are Whig/radical, Local newspapers, Emp. Herfindahl index, Population density and Army career. When tested down by a general-to-specific algorithm, petition is significant at the 1 percent level in col. (9). b. Net seat gain proposal is coded from the seat distribution included in the schedules A to $\mathrm{G}$ in the draft bill presented in March 1831 . *** $\mathrm{p}<0.01$, ** $\mathrm{p}<0.05$, * $\mathrm{p}<0.1$. 


\section{A2: Results without London}

Being the capital, London, was at the center of public protest and agitation during the period. This motivates studying two samples: one where we consider all the English MPs (the full sample considered in the text) and one where we exclude the MPs elected in the City of London, in Westminster and in the county of Middlesex (which we henceforth refer to as London). Table A3 reproduces Table 6 for the sample without London. We observe that the results are less precisely estimated, but otherwise similar. 
Table A3. The effect of different types of violent and peaceful protest on a MP's probability of voting in favor of the reform bill: Probit estimates excluding London.

\begin{tabular}{|c|c|c|c|c|c|c|c|c|c|}
\hline \multirow[t]{2}{*}{ Dependent Var. } & \multicolumn{9}{|c|}{ Yes vote } \\
\hline & (1) & (2) & (3) & (4) & (5) & (6) & (7) & (8) & (9) \\
\hline Violent unrest & $\begin{array}{l}0.045 \\
(0.18)\end{array}$ & & & & & & & & \\
\hline Peaceful protest & & $\begin{array}{c}0.015 \\
(0.0077) *\end{array}$ & & & & & & & \\
\hline Rural violent & & & $\begin{array}{l}-0.19 \\
(0.15)\end{array}$ & & & & & & $\begin{array}{l}-0.21 \\
(0.16)\end{array}$ \\
\hline Urban violent & & & & $\begin{array}{c}0.35 \\
(0.19)^{*}\end{array}$ & & & & & $\begin{array}{c}0.25 \\
(0.23)\end{array}$ \\
\hline Meetings & & & & & $\begin{array}{c}0.016 \\
(0.011)\end{array}$ & & & & \\
\hline Gatherings & & & & & & $\begin{array}{c}0.017 \\
(0.0097)^{*}\end{array}$ & & & \\
\hline Reform agitation & & & & & & & $\begin{array}{c}0.023 \\
(0.0098)^{* *}\end{array}$ & & $\begin{array}{c}0.011 \\
(0.012)\end{array}$ \\
\hline Petitions & & & & & & & & $\begin{array}{c}0.044 \\
(0.019)^{* *}\end{array}$ & $\begin{array}{c}0.048 \\
(0.020)^{* *}\end{array}$ \\
\hline Net seat gain & $\begin{array}{c}0.012 \\
(0.0028)^{* * *}\end{array}$ & $\begin{array}{c}0.0074 \\
(0.0040)^{*}\end{array}$ & $\begin{array}{c}0.010 \\
(0.0034)^{* * *}\end{array}$ & $\begin{array}{c}0.0091 \\
(0.0036)^{* *}\end{array}$ & $\begin{array}{c}0.0094 \\
(0.0037)^{* *}\end{array}$ & $\begin{array}{c}0.0090 \\
(0.0033)^{* * *}\end{array}$ & $\begin{array}{c}0.0097 \\
(0.0033)^{* * *}\end{array}$ & $\begin{array}{c}0.012 \\
(0.0029)^{* * *}\end{array}$ & $\begin{array}{c}0.0084 \\
(0.0042)^{* *}\end{array}$ \\
\hline Disenfranchised & $\begin{array}{c}-0.077 \\
(0.088)\end{array}$ & $\begin{array}{l}-0.095 \\
(0.091)\end{array}$ & $\begin{array}{l}-0.075 \\
(0.087)\end{array}$ & $\begin{array}{c}-0.082 \\
(0.091)\end{array}$ & $\begin{array}{l}-0.089 \\
(0.091)\end{array}$ & $\begin{array}{l}-0.086 \\
(0.088)\end{array}$ & $\begin{array}{l}-0.079 \\
(0.088)\end{array}$ & $\begin{array}{l}-0.019 \\
(0.092)\end{array}$ & $\begin{array}{l}-0.016 \\
(0.097)\end{array}$ \\
\hline Patron controlled & $\begin{array}{c}-0.092 \\
(0.11)\end{array}$ & $\begin{array}{l}-0.095 \\
(0.11)\end{array}$ & $\begin{array}{r}-0.089 \\
(0.11)\end{array}$ & $\begin{array}{c}-0.082 \\
(0.11)\end{array}$ & $\begin{array}{l}-0.087 \\
(0.11)\end{array}$ & $\begin{array}{l}-0.10 \\
(0.11)\end{array}$ & $\begin{array}{c}-0.086 \\
(0.11)\end{array}$ & $\begin{array}{l}-0.071 \\
(0.11)\end{array}$ & $\begin{array}{c}-0.054 \\
(0.11)\end{array}$ \\
\hline Landed interest & $\begin{array}{c}0.26 \\
(0.067)^{* * *}\end{array}$ & $\begin{array}{c}0.27 \\
(0.066)^{* * *}\end{array}$ & $\begin{array}{c}0.25 \\
(0.067)^{* * *}\end{array}$ & $\begin{array}{c}0.25 \\
(0.067)^{* * *}\end{array}$ & $\begin{array}{c}0.26 \\
(0.067)^{* * *}\end{array}$ & $\begin{array}{c}0.27 \\
(0.067)^{* * *}\end{array}$ & $\begin{array}{c}0.26 \\
(0.068)^{* * *}\end{array}$ & $\begin{array}{c}0.26 \\
(0.065)^{* * *}\end{array}$ & $\begin{array}{c}0.26 \\
(0.066)^{* * *}\end{array}$ \\
\hline Controls & YES & YES & YES & YES & YES & YES & YES & YES & YES \\
\hline Observations & 458 & 458 & 458 & 458 & 458 & 458 & 458 & 458 & 458 \\
\hline
\end{tabular}

Note: The eight MPs from the City of London, Westminster and the county of Middlesex are excluded. Probit estimates. Marginal effects evaluated at the mean of the explanatory variables. Constant not shown. Standard errors in parentheses are clustered at the county level. Sample restricted to the English MPs who were present in the House of Commons on 22 March 1831. Peaceful protest is sum of Meetings and Gatherings. Violent unrest is the sum of rural violent and urban violent. Controls included are Whig/radical, Local newspapers, Emp. Herfindahl index, Population density and Army career. When tested down by a general-to-specific algorithm, petition is significant at the 5 percent level and reform agitation is significant at the 5 percent level in col. (9). *** $\mathrm{p}<0.01, * * \mathrm{p}<0.05, * \mathrm{p}<0.1$. 


\section{A3. Additional control variables and MP characteristics}

We collected information on the personal characteristics of the English MPs that were elected in July 1830 to the House of Commons. The main source is Fisher, David (ed.), 2009, The History of Parliament: The House of Commons 1820-1832, Cambridge, Cambridge University Press, 2009 and the material from http://www.historyofparliamentonline.org/ (accessed 17 September 2017). The characteristics relate to the MPs' occupation, age, education, and years served in parliament, as well as whether they had taken a Grand Tour, were part of a dynasty that returned MPs generation after generation or had relatives in the current parliament. In the results reported in the main body of the paper, we only include one of these characteristics, army career. The reason is that none of the other characteristics can predict the voting behavior, neither individually, in groups or altogether. Table A4 reports representative results. We observe that the effect of the variables of interest (all protest) and the variables related to political expedience are not affected by the inclusion or not of the personal characteristics.

We examine the robustness of the results in Table 5, column 3 to the inclusion of additional potentially confounding factors. Some of these variables can be viewed as endogenous to the intensity of public protest which motivates their exclusion from the baseline analysis. The variables pertain to economic and demographic characteristics from the 1831 Population Census, including employment shares (Agriculture (emp. share), Trade (emp. share), and Professionals (emp. share)), two indicator variables coded from the contextual information in Philbin (1965), capturing whether the constituency was thriving or declining in 1830 (Thriving economy and Declining economy), an index of the county-level wealth distribution (Top wealth, high wealth and medium wealth) based on a 1815 property value survey and reported in the 1831 Population Census $^{33}$, and two features of the suffrage rules captured by a separate indicator for the university

\footnotetext{
${ }^{33}$ These data are reported in the 1831 Population Census in the table "Population. Comparative account of the population of Great Britain in the years 1801, 1811, 1821 and 1831 (348)." They were collected for the purpose of
} 
seats (university) and an indicator variable indicating whether the suffrage in each borough constituency was narrow or broad (Narrow franchise). Table A5 reports the results when we add these variables to our preferred specification from Table 5, column 3. We find that none of these variables is significant. More importantly, including them neither modifies the size and significance of public protests on the MPs' vote nor affects our conclusions regarding political expedience.

levying taxes. While the parish level data may contain measurement error, the county averages are likely to give a fairly accurate estimate of the county differences in average property values. To reduce measurement error, we divide the counties into three groups rather than using the average property values directly. 
Table A4: The relationship between personal characteristics and the probability that an MP voted in favor of the reform bill on 22 March 1831: Probit estimates.

\begin{tabular}{|c|c|c|c|c|}
\hline \multirow[t]{2}{*}{ Dependent variable } & \multicolumn{4}{|c|}{ Yes vote } \\
\hline & (1) & $(2)$ & (3) & $(4)$ \\
\hline \multirow[t]{2}{*}{ All protest } & $0.015 * *$ & $0.015^{*}$ & $0.015 * *$ & $0.015 * *$ \\
\hline & $(0.0072)$ & $(0.0077)$ & $(0.0076)$ & $(0.0071)$ \\
\hline \multirow[t]{2}{*}{ Net seat gain } & $0.0071 *$ & $0.0069 *$ & $0.0077 *$ & $0.0071^{*}$ \\
\hline & $(0.0040)$ & $(0.0040)$ & $(0.0041)$ & $(0.0038)$ \\
\hline \multirow[t]{2}{*}{ Disenfranchised } & -0.10 & -0.10 & -0.11 & -0.099 \\
\hline & $(0.093)$ & $(0.093)$ & $(0.095)$ & $(0.091)$ \\
\hline \multirow[t]{2}{*}{ Patron controlled } & -0.10 & -0.096 & -0.088 & -0.10 \\
\hline & $(0.10)$ & $(0.10)$ & $(0.11)$ & $(0.10)$ \\
\hline \multirow[t]{2}{*}{ Landed interest } & $0.27 * * *$ & $0.29 * * *$ & $0.29 * * *$ & $0.27 * * *$ \\
\hline & $(0.071)$ & $(0.066)$ & $(0.070)$ & $(0.065)$ \\
\hline \multirow[t]{2}{*}{ Whig/radical } & $0.84 * * *$ & $0.84 * * *$ & $0.84 * * *$ & $0.84 * * *$ \\
\hline & $(0.028)$ & $(0.029)$ & $(0.028)$ & $(0.029)$ \\
\hline \multirow[t]{2}{*}{ Local newspapers } & -0.00015 & -0.00015 & -0.00018 & -0.00020 \\
\hline & $(0.00032)$ & $(0.00035)$ & $(0.00032)$ & $(0.00029)$ \\
\hline \multirow[t]{2}{*}{ Emp. Herfindahl index } & $-1.19 * *$ & $-1.12 * *$ & $-1.24 * *$ & $-1.18 * *$ \\
\hline & $(0.52)$ & $(0.54)$ & $(0.55)$ & $(0.53)$ \\
\hline \multirow[t]{2}{*}{ Population density } & -0.029 & -0.030 & -0.031 & -0.026 \\
\hline & $(0.041)$ & $(0.039)$ & $(0.038)$ & $(0.039)$ \\
\hline \multirow[t]{2}{*}{ Army career } & -0.15 & & -0.18 & $-0.16^{*}$ \\
\hline & $(0.094)$ & & $(0.11)$ & $(0.087)$ \\
\hline \multirow[t]{2}{*}{ Financier } & -0.036 & & -0.011 & \\
\hline & $(0.18)$ & & $(0.19)$ & \\
\hline \multirow[t]{2}{*}{ Industrialist } & 0.0072 & & -0.020 & \\
\hline & $(0.22)$ & & $(0.21)$ & \\
\hline \multirow[t]{2}{*}{ Jurist } & 0.058 & & 0.0014 & \\
\hline & $(0.089)$ & & $(0.12)$ & \\
\hline \multirow[t]{2}{*}{ Merchant } & 0.015 & & 0.0021 & \\
\hline & $(0.15)$ & & $(0.15)$ & \\
\hline \multirow[t]{2}{*}{ Age (of MP) } & & 0.0013 & 0.00062 & \\
\hline & & $(0.0027)$ & $(0.0027)$ & \\
\hline \multirow[t]{2}{*}{ Years in Parliament } & & -0.0040 & -0.0039 & \\
\hline & & $(0.0043)$ & $(0.0041)$ & \\
\hline \multirow[t]{2}{*}{ Education } & & 0.13 & 0.14 & \\
\hline & & $(0.092)$ & $(0.087)$ & \\
\hline \multirow[t]{2}{*}{ Grand tour } & & 0.064 & 0.034 & \\
\hline & & $(0.10)$ & $(0.10)$ & \\
\hline \multirow[t]{2}{*}{ Dynasty heir } & & -0.030 & -0.087 & \\
\hline & & $(0.068)$ & $(0.096)$ & \\
\hline \multirow[t]{2}{*}{ Relative in parliament } & & -0.10 & -0.059 & \\
\hline & & $(0.083)$ & $(0.083)$ & \\
\hline
\end{tabular}

Note: Probit estimator. N=466. Marginal effects evaluated at the mean. Constant not shown. Standard errors in parentheses are clustered at the county level. Col. (4) tests down using a general-to-specific algorithm, leaving only the significant personal characteristics. $* * * p<0.01, * * \mathrm{p}<0.05, * \mathrm{p}<0.1$. 
Table A5: The effect of public protest on a MP's vote in favor of the reform bill: Probit estimates with extra control variables

\begin{tabular}{|c|c|c|c|c|c|}
\hline \multirow[t]{2}{*}{ Dependent variable } & \multicolumn{5}{|c|}{ Yes vote } \\
\hline & (1) & (2) & (3) & (4) & (5) \\
\hline \multirow[t]{2}{*}{ All protest } & 0.015 & 0.016 & 0.014 & 0.014 & 0.014 \\
\hline & $(0.0073)^{* *}$ & $(0.0072)^{* *}$ & $(0.0067)^{* *}$ & $(0.0069)^{* *}$ & $(0.0069)^{* *}$ \\
\hline \multirow[t]{2}{*}{ Net seat gain } & 0.0065 & 0.0071 & 0.0064 & 0.0099 & 0.0082 \\
\hline & $(0.0038) *$ & $(0.0038)^{*}$ & $(0.0043)$ & $(0.0043)^{* *}$ & $(0.0050) *$ \\
\hline \multirow[t]{2}{*}{ Disenfranchised } & -0.097 & -0.082 & -0.044 & -0.096 & -0.017 \\
\hline & $(0.089)$ & $(0.095)$ & $(0.11)$ & $(0.085)$ & $(0.10)$ \\
\hline \multirow[t]{2}{*}{ Patron controlled } & -0.089 & -0.096 & -0.091 & -0.10 & -0.077 \\
\hline & $(0.11)$ & $(0.10)$ & $(0.11)$ & $(0.10)$ & $(0.11)$ \\
\hline \multirow[t]{2}{*}{ Landed interest } & 0.26 & 0.26 & 0.33 & 0.27 & 0.31 \\
\hline & $(0.066)^{* * *}$ & $(0.063) * * *$ & $(0.077) * * *$ & $(0.067) * * *$ & $(0.086)^{* * *}$ \\
\hline \multirow[t]{2}{*}{ Whig/radical } & 0.84 & 0.84 & 0.84 & 0.84 & 0.84 \\
\hline & $(0.030)^{* * *}$ & $(0.029)^{* * *}$ & $(0.028)^{* * *}$ & $(0.028)^{* * *}$ & $(0.028)^{* * *}$ \\
\hline \multirow[t]{2}{*}{ Local newspapers } & -0.00016 & -0.00022 & -0.00024 & -0.000095 & -0.00014 \\
\hline & $(0.00028)$ & $(0.00030)$ & $(0.00026)$ & $(0.00036)$ & $(0.00032)$ \\
\hline \multirow[t]{2}{*}{ Emp. Herfindahl index } & -1.18 & -1.16 & -1.10 & -1.11 & -1.07 \\
\hline & $(0.51)^{* *}$ & $(0.52)^{* *}$ & $(0.51)^{* *}$ & $(0.50) * *$ & $(0.48)^{* *}$ \\
\hline \multirow[t]{2}{*}{ Population density } & -0.031 & -0.027 & -0.033 & -0.047 & -0.057 \\
\hline & $(0.039)$ & $(0.040)$ & $(0.043)$ & $(0.041)$ & $(0.047)$ \\
\hline \multirow[t]{2}{*}{ Army career } & -0.17 & -0.16 & -0.17 & -0.16 & -0.17 \\
\hline & $(0.085)^{* *}$ & $(0.086)^{*}$ & $(0.081)^{* *}$ & $(0.086)^{*}$ & $(0.079)^{* *}$ \\
\hline \multirow[t]{2}{*}{ University constituency } & -0.11 & & & & -0.017 \\
\hline & $(0.21)$ & & & & $(0.10)$ \\
\hline \multirow[t]{2}{*}{ Narrow franchise } & -0.076 & & & & -0.069 \\
\hline & $(0.075)$ & & & & $(0.075)$ \\
\hline \multirow[t]{2}{*}{ Thriving economy } & & -0.022 & & & -0.13 \\
\hline & & $(0.093)$ & & & $(0.23)$ \\
\hline \multirow[t]{2}{*}{ Declining economy } & & -0.071 & & & -0.064 \\
\hline & & $(0.084)$ & & & $(0.075)$ \\
\hline \multirow[t]{2}{*}{ Agriculture (emp. share) } & & & 0.067 & & 0.016 \\
\hline & & & $(0.52)$ & & $(0.52)$ \\
\hline \multirow[t]{2}{*}{ Trade (emp. share) } & & & 0.37 & & 0.29 \\
\hline & & & $(0.53)$ & & $(0.52)$ \\
\hline \multirow[t]{2}{*}{ Professionals (emp. share) } & & & 1.72 & & 1.82 \\
\hline & & & $(1.61)$ & & $(1.51)$ \\
\hline \multirow[t]{2}{*}{ Top wealth } & & & & -0.072 & -0.060 \\
\hline & & & & $(0.10)$ & $(0.11)$ \\
\hline \multirow[t]{2}{*}{ High wealth } & & & & -0.066 & -0.041 \\
\hline & & & & $(0.11)$ & $(0.13)$ \\
\hline \multirow[t]{2}{*}{ Medium wealth } & & & & -0.16 & -0.14 \\
\hline & & & & $(0.11)$ & $(0.11)$ \\
\hline Observations & 466 & 466 & 466 & 466 & 466 \\
\hline
\end{tabular}

Note: Probit estimator. Marginal effects evaluated at the mean of the explanatory variables. Standard errors in parentheses are clustered at the county level. Constant not shown. Sample restricted to the English MPs who were present in the House of Commons on 22 March 1831 and voted. $* * * p<0.01, * * \mathrm{p}<0.05, * \mathrm{p}<0.1$. 


\section{A4: Correlation matrix between protest variables and petitions}

Table A6 shows the correlation matrix for the variables used to capture violent unrest and public agitation. We see that some of the variables are highly correlated, with correlation coefficients as high as 0.75 , but most of them are modestly correlated.

Table A6: Correlation matrix for violent unrest, peaceful protest and petitions

\begin{tabular}{l|cccccc}
\hline & $\begin{array}{c}\text { Rural } \\
\text { violence }\end{array}$ & $\begin{array}{c}\text { Urban } \\
\text { Violence }\end{array}$ & Meetings & Gatherings & $\begin{array}{c}\text { Reform } \\
\text { agitation }\end{array}$ & Petitions \\
\hline Rural violence & 1 & & & & & \\
Urban violence & $-0.140^{* *}$ & 1 & & & & \\
Meetings & $-0.183^{* * *}$ & $0.757^{* * *}$ & 1 & & & \\
Gatherings & $-0.119^{* *}$ & $0.236^{* * *}$ & $0.251^{* * *}$ & 1 & & \\
Reform agitation & $-0.109^{*}$ & $0.437^{* * *}$ & $0.436^{* * *}$ & $0.709^{* * *}$ & 1 & 1 \\
Petitions & 0.064 & $0.563^{* * *}$ & $0.413^{* * *}$ & 0.059 & 0.148 & 1 \\
\hline
\end{tabular}

Note: $* * * \mathrm{p}<0.01, * * \mathrm{p}<0.05, * \mathrm{p}<0.1$ 


\section{A5. Attendance at the second reading on 22 March 1831}

Using the bibliographic information reported by Fisher, David (ed.), 2009, The History of Parliament: The House of Commons 1820-1832, Cambridge, Cambridge University Press, and the material available online at http://www.historyofparliamentonline.org/ (accessed 17 September 2017), we list in Table A7 the four seats which were vacant on 22 March 1831 and report the reasons why the elections of the MPs to these seats were cancelled. Furthermore, as a follow-up to Table 8 where we compute the probability that each MP would have supported reform had they been present, the counterfactual analysis in Table A8 assigns a vote outcome to the absent MPs' by examining the changes in the level of riots and constituencies' characteristics. We find that low levels of protest would have led nearly $60 \%$ of the 18 absent MPs to support reform but only extreme levels of protest would have induced all of them to support reform. Finally, in Table A9, we report the remainder of the counterfactual exercise in Table 8 for the all protest, peaceful protest, gatherings and meetings variables. 
Table A7. Seats without Representation in the House of Commons, 22 March 1831

\begin{tabular}{|c|c|c|c|c|c|}
\hline Borough & County & MP & Affiliation & Occupation & Reason for cancellation \\
\hline Colchester & Essex & Andrew Spottiswoode & Tory & Merchant & $\begin{array}{l}\text { On } 21 \text { March 1831, the election committee cancelled his election, arguing that } \\
\text { Spottiswoode was disqualified by his patent as King's printer. }\end{array}$ \\
\hline Durham City & Durham County & Roger Gresley & Tory & Landowner & $\begin{array}{l}\text { On } 8 \text { March 1831, the election of Gresley (but not of Michael Angelo Taylor, the } \\
\text { other MP for Durham City) was cancelled because of bribery and intimidation. } \\
\text { While Gresley reentered the House of Commons on } 19 \text { March } 1831 \text { for New } \\
\text { Romney, the new MP for Durham City, William Richard Carter Chaytor, only } \\
\text { entered Parliament on } 23 \text { March } 1831 \text {. }\end{array}$ \\
\hline Evesham & Worcestershire & $\begin{array}{l}\text { Charles Cockerell } \\
\text { Archibald Kennedy }\end{array}$ & $\begin{array}{l}\text { Tory } \\
\text { Tory }\end{array}$ & $\begin{array}{l}\text { Landowner } \\
\text { Merchant }\end{array}$ & $\begin{array}{l}\text { On } 13 \text { December 1830, the election committee cancelled the elections of Charles } \\
\text { Cokerell and Archibald Kennedy who were found guilty of bribery. No new } \\
\text { election took place until the dissolution of April } 1831 \text {. }\end{array}$ \\
\hline
\end{tabular}

Source: Fisher, David (ed.), 2009, The History of Parliament: The House of Commons 1820-1832, Cambridge, Cambridge University Press. 
Table A8. Absent MPs' vote: A counterfactual analysis

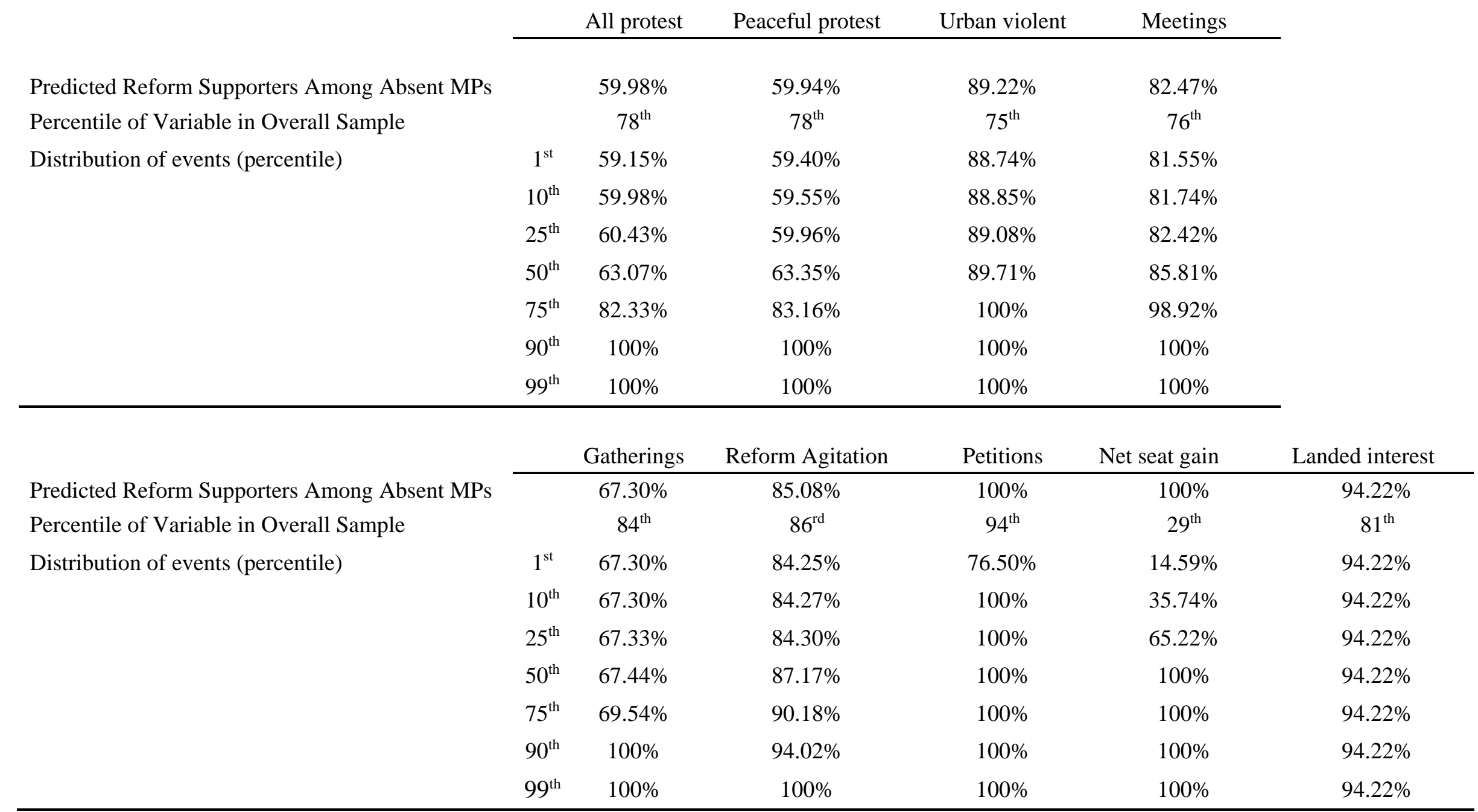

Note: This table provides a counterfactual analysis for the vote of absent MPs on 22 March 1831. For each variable of protest and constituency characteristics, we report three sets of results. First, we report the predicted percentage that the 18 absent MPs would have supported reform based on their observable characteristics. Second, we report where the average value of each variable in the sample of $18 \mathrm{MPs}$ is located in the overall distribution of each variable. Third, we determine its value at the $1^{\text {st }}, 10^{\text {th }}, 25^{\text {th }}, 50^{\text {th }}, 75^{\text {th }}$, $90^{\text {th }}$ and $99^{\text {th }}$ percentile of the distribution, rerun the relevant regression and compute the predicted probability that the 18 absent MPs would have supported reform. 
Table A9. Counterfactual analysis of the levels of protest and constituencies' characteristics on the MPs' votes

\begin{tabular}{|c|c|c|c|c|c|c|c|c|}
\hline \multirow[b]{2}{*}{$\begin{array}{l}\text { Distribution } \\
\text { of events }\end{array}$} & \multicolumn{2}{|c|}{ All protest } & \multicolumn{2}{|c|}{ Peaceful protest } & \multicolumn{2}{|c|}{ Gatherings } & \multicolumn{2}{|c|}{ Meetings } \\
\hline & $\begin{array}{l}\text { Predicted } \\
\text { Reform } \\
\text { Support }\end{array}$ & $\begin{array}{c}\text { Predicted } \\
\text { Reform Support } \\
\text { of English MPs }\end{array}$ & $\begin{array}{l}\text { Predicted } \\
\text { Reform } \\
\text { Support }\end{array}$ & $\begin{array}{l}\text { Predicted Reform } \\
\text { Support of } \\
\text { English MPs }\end{array}$ & $\begin{array}{l}\text { Predicted } \\
\text { Reform } \\
\text { Support }\end{array}$ & $\begin{array}{c}\text { Predicted } \\
\text { Reform Support } \\
\text { of English MPs }\end{array}$ & $\begin{array}{l}\text { Predicted } \\
\text { Reform } \\
\text { Support }\end{array}$ & $\begin{array}{l}\text { Predicted Reform } \\
\text { Support of } \\
\text { English MPs }\end{array}$ \\
\hline \multirow[t]{2}{*}{$1 \mathrm{st}$} & $46.75 \%$ & 218 & $46.84 \%$ & 218 & $47.61 \%$ & 222 & $47.64 \%$ & 222 \\
\hline & {$[0.015]$} & $\{204 ; 232\}$ & {$[0.015]$} & $\{205 ; 232\}$ & [0.013] & $\{210 ; 234\}$ & {$[0.016]$} & $\{208 ; 236\}$ \\
\hline \multirow[t]{2}{*}{ 10th } & $46.84 \%$ & 218 & $46.86 \%$ & 218 & $47.61 \%$ & 222 & $47.66 \%$ & 222 \\
\hline & [0.015] & $\{205 ; 232\}$ & {$[0.015]$} & $\{205 ; 232\}$ & [0.013] & $\{210 ; 234\}$ & {$[0.016]$} & $\{208 ; 236\}$ \\
\hline \multirow[t]{2}{*}{ 25th } & $46.88 \%$ & 218 & $46.90 \%$ & 219 & $47.62 \%$ & 222 & $47.71 \%$ & 222 \\
\hline & {$[0.015]$} & $\{205 ; 232\}$ & {$[0.015]$} & $\{205 ; 232\}$ & [0.013] & $\{210 ; 234\}$ & {$[0.016]$} & $\{208 ; 237\}$ \\
\hline \multirow[t]{2}{*}{ 50th } & $47.15 \%$ & 220 & $47.24 \%$ & 220 & $47.63 \%$ & 222 & $47.99 \%$ & 224 \\
\hline & {$[0.014]$} & $\{207 ; 233\}$ & {$[0.014]$} & $\{207 ; 233\}$ & [0.013] & $\{210 ; 234\}$ & {$[0.015]$} & $\{210 ; 237\}$ \\
\hline \multirow[t]{2}{*}{ 75th } & $48.89 \%$ & 228 & $49.02 \%$ & 228 & $47.82 \%$ & 223 & $49.00 \%$ & 228 \\
\hline & [0.013] & $\{216 ; 239\}$ & [0.013] & $\{217 ; 240\}$ & {$[0.014]$} & $\{211 ; 235\}$ & [0.014] & $\{216 ; 241\}$ \\
\hline \multirow[t]{2}{*}{ 90th } & $52.41 \%$ & 244 & $52.64 \%$ & 245 & $51.91 \%$ & 242 & $51.16 \%$ & 238 \\
\hline & {$[0.023]$} & $\{223 ; 265\}$ & [0.024] & $\{223 ; 268\}$ & [0.025] & $\{219 ; 265\}$ & [0.016] & $\{224 ; 253\}$ \\
\hline \multirow[t]{2}{*}{ 99th } & $63.80 \%$ & 297 & $64.08 \%$ & 299 & $63.17 \%$ & 294 & $62.14 \%$ & 290 \\
\hline & {$[0.084]$} & $\{221 ; 374\}$ & [0.088] & $\{218 ; 379\}$ & {$[0.098]$} & $\{205 ; 384\}$ & {$[0.071]$} & $\{225 ; 354\}$ \\
\hline
\end{tabular}

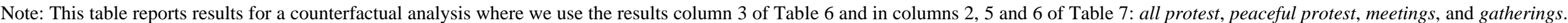

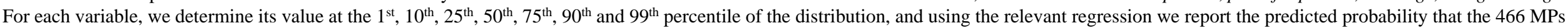
would have voted for reform (with 95 percent confidence intervals in curly brackets). Standard errors for the predicted values are reported in square brackets. 


\section{A6. Overall protests and the support for reform: An IV approach}

In this section, we report instrumental variables results that help bolster the causal interpretation of the effect of public protest on the MP's vote. For this purpose, we need an instrumental variable that, on the one hand, explains the geographic pattern of protest and, on the other hand, influences the MPs' vote decisions only through its effect on public protest. We conjecture that public protest is influenced by population pressure in an area, which is, conditional on the party affiliation of the MPs and the other control variables, not a factor in the MPs' vote decisions. Specifically, as an instrument for protest in county $c$, we propose the variable population pressure1811-1831,c. It is defined as the interaction between the average population growth rate between 1811 and 1831 and population density in county $c$ in 1811 . We then estimate an IV-probit model with a maximum likelihood estimator which jointly estimate the parameters of equation (1) from the main body of the text and the parameters of the equation capturing the relationship between the endogenous variable (all protest) and the instrument:

$$
(\text { all protest })_{c}=\gamma_{0}+\gamma_{1} \text { populationpressure } 1_{1811-1831, c}+X_{k, d, c} \gamma_{2}+u_{c}
$$

where $u_{c}$ is an error term which is normally distributed. The other variables are defined in equation 1 in the main body of the text.

Table A10 reports three sets of the IV-Probit estimate of equations (1) and (IV). For each set, we report the estimate of $\gamma_{1}$ from equation (IV) and the estimate of the coefficient on all protest from equation 1 . Columns 1 and 2 show the results for all protest defined as the total number of participants, columns 3 and 4 show the results for all protest defined as the total number of participants per capita, and columns 5 and 6 show the results for all protest defined as the total number of protest events. We observe that population pressure 1811-1831,c has a positive 
and significant impact on the scale of protests in all cases. ${ }^{34}$ The IV estimate of the coefficient on all protest (\# participants) is positive but imprecisely estimated with a p-value of 0.14 , while the coefficients on all protest (\# participants per capita) and all protest (\# events) are significant at the ten percent level, but about seven times larger than the corresponding estimate obtained from the regular Probit regression reported at the bottom of the table. The Wald test also reported at the bottom of Table A10 does not reject the null hypothesis of no endogeneity. The regular Probit regression may, therefore, be appropriate.

${ }^{34}$ Since we only have one instrument, we cannot investigate the violent unrest and peaceful protest separately. 
Table A10: Effect of protest on the probability that a MP voted in favor of the reform bill on 22 March 1831: IV-probit estimates.

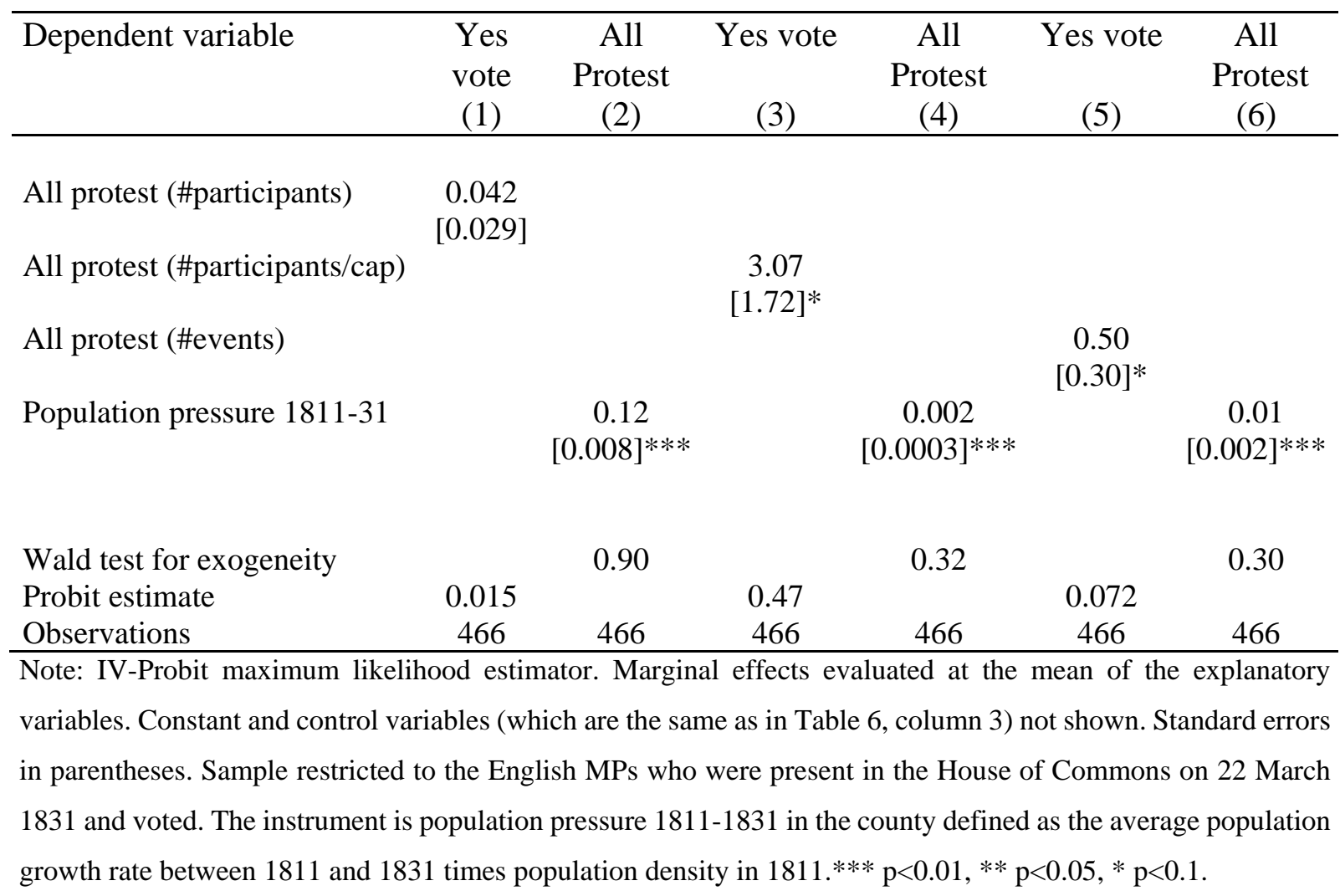




\section{A7. Descriptive statistics}

Table A11: Descriptive statistics for the (new) variables used in Tables A1, A2 and A5.

Obs. Mean Std. Dev. Min. Max.

Public protest

All protest (\# events)

Violent unrest (\# events)

Peaceful protest (\# events)

Rural violent (\# events)

Urban violent (\# events)

Meetings (\# events)

Gatherings (\# events)

Reform agitation (\# events)

All protest (\# participants per capita)

All protest (\# participants per adult male)

Demographic and economic controls

Top wealth

High wealth

Medium wealth

Institutional controls

University constituency

Narrow franchise

Expected consequences of reform

Net seat gain $(\%)$

Net seat gain proposal

Demographic and economic controls

Local newspapers per capita

Thriving economy

Declining economy

Agriculture (emp. share)

Trade (emp. share)

Professionals (emp. share)

\section{County-Level Variation}

$\begin{array}{ccccc}489 & 0.78 & 1.13 & 0.0100 & 9.05 \\ 489 & 0.19 & 0.24 & 0 & 1.99 \\ 489 & 0.60 & 0.92 & 0.0100 & 7.06 \\ 489 & 0.094 & 0.14 & 0 & 0.43 \\ 489 & 0.092 & 0.22 & 0 & 1.99 \\ 489 & 0.52 & 0.81 & 0.0100 & 6.19 \\ 489 & 0.077 & 0.12 & 0 & 0.87 \\ 489 & 0.12 & 0.13 & 0 & 0.95 \\ 489 & 0.082 & 0.19 & 0.0002 & 1.93 \\ 489 & 0.33 & 0.68 & 0.0007 & 6.64 \\ & & & & \\ 489 & 0.19 & 0.40 & 0 & 1 \\ 489 & 0.24 & 0.43 & 0 & 1 \\ 489 & 0.25 & 0.43 & 0 & 1\end{array}$

Constituency-Level Variation

$\begin{array}{ccccc}489 & 0.0082 & 0.090 & 0 & 1 \\ 489 & 0.24 & 0.43 & 0 & 1 \\ & & & & \\ 489 & -3.68 & 43.4 & -66.7 & 150 \\ 489 & -5.91 & 9.48 & -31 & 6 \\ & & & & \\ 489 & 4.71 & 24.2 & 0 & 245 \\ 489 & 0.18 & 0.38 & 0 & 1 \\ 489 & 0.21 & 0.41 & 0 & 1 \\ 489 & 0.19 & 0.18 & 0 & 1 \\ 489 & 0.37 & 0.13 & 0 & 0.87 \\ 489 & 0.055 & 0.027 & 0 & 0.14\end{array}$

Note: The sample is restricted to the 489 English seats. The protest variables related to the number of events is recorded in 100s. 
Table A12: Summary statistics for the (English) MPs' personal characteristics used in Table A4 and Table 10.

\begin{tabular}{lccccc}
\hline & $\mathrm{N}$ & Mean & sd & $\min$ & $\max$ \\
\hline & & & & & \\
Army career & 466 & 0.18 & 0.39 & 0 & 1 \\
Financier & 466 & 0.055 & 0.23 & 0 & 1 \\
Industrialist & 466 & 0.051 & 0.22 & 0 & 1 \\
Jurist & 466 & 0.13 & 0.33 & 0 & 1 \\
Merchant & 466 & 0.090 & 0.29 & 0 & 1 \\
Age of MP & 466 & 44.8 & 13.0 & 21 & 79 \\
Years in Parliament & 466 & 11.2 & 10.5 & 1 & 51 \\
Education & 466 & 0.73 & 0.44 & 0 & 1 \\
Grand tour & 466 & 0.077 & 0.27 & 0 & 1 \\
Dynasty heir & 466 & 0.42 & 0.49 & 0 & 1 \\
Relative in parliament & 466 & 0.61 & 0.49 & 0 & 1 \\
Landowner & 466 & 0.45 & 0.50 & 0 & 1
\end{tabular}

Note: Education is equal to 1 if the MP has at least secondary education. The sample is restricted to the 466 English MPs who voted on the bill.

Table A13: Descriptive statistics for the constituency sample used in Table 11.

\begin{tabular}{|c|c|c|c|c|c|}
\hline & Obs. & Mean & Std. Dev. & Min. & Max. \\
\hline & \multicolumn{5}{|c|}{ County-Level Variation } \\
\hline \multicolumn{6}{|l|}{ Public protest participation } \\
\hline All protest (10000s) & 244 & 1.52 & 3.05 & 0 & 15.8 \\
\hline Violent unrest (10000s) & 244 & 0.094 & 0.20 & 0 & 0.94 \\
\hline Peaceful protest (10000s) & 244 & 1.42 & 2.93 & 0 & 14.9 \\
\hline Petitions & 244 & 1.36 & 2.31 & -2 & 27 \\
\hline \multicolumn{6}{|l|}{ Expected consequences of reform } \\
\hline Net seat gain & 244 & -4.01 & 9.52 & -28 & 12 \\
\hline \multicolumn{6}{|l|}{ Institutional controls } \\
\hline \multirow[t]{2}{*}{ Local newspapers } & 244 & 15.3 & 59.6 & 0 & 303 \\
\hline & \multicolumn{5}{|c|}{ Constituency-Level Variation } \\
\hline \multicolumn{6}{|l|}{ Political controls } \\
\hline Whig share in 1830 & 244 & 42.9 & 37.9 & 0 & 100 \\
\hline Whig share in 1826 & 244 & 39.2 & 39.4 & 0 & 100 \\
\hline \multicolumn{6}{|l|}{ Expected consequences of reform } \\
\hline Disenfranchised & 244 & 0.23 & 0.42 & 0 & 1 \\
\hline Landed interest & 244 & 0.17 & 0.37 & 0 & 1 \\
\hline Patron controlled & 244 & 0.77 & 0.42 & 0 & 1 \\
\hline \multicolumn{6}{|c|}{ Demographic and economic controls } \\
\hline Emp. Herfindahl index (1831) & 244 & 0.76 & 0.073 & 0.24 & 0.86 \\
\hline Population density (1831) & 244 & 5.56 & 0.84 & 3.92 & 9.79 \\
\hline
\end{tabular}

Note: The sample is restricted to the 244 English constituencies. 
Table A14: Descriptive statistics for the new variables used in Table 12 and Table A10.

Obs. Mean Std. Dev. Min. Max.

Support for parliamentary reform

Yes vote, 1810

Yes vote, 1822

Members of Parliament

Whig/radical 1810

Whig/radical 1822

Expected consequences of reform

Net seat gain

Institutional controls

Local newspapers

Instrumental variable

Population pressure 1811-31

Expected consequences of reform

Disenfranchised

Landed interest

Political controls

Uncontested elections, 1810

Uncontested elections, 1822

Demographic and economic controls

Emp. Herfindahl index, 1811

Emp. Herfindahl index, 1821

Population density, 1811

Population density, 1821
Seat-Level Variation

$\begin{array}{lllll}487 & 0.18 & 0.38 & 0 & 1 \\ 487 & 0.29 & 0.46 & 0 & 1 \\ & & & & \\ 486 & 0.34 & 0.47 & 0 & 1 \\ 487 & 0.41 & 0.49 & 0 & 1\end{array}$

County-Level Variation

$\begin{array}{ccccc}489 & -4.01 & 9.51 & -28 & 12 \\ 489 & 16.6 & 62.3 & 0 & 303 \\ 489 & 93.9 & 27.2 & 38.4 & 160.0\end{array}$

Constituency-Level Variation

$\begin{array}{ccccc}489 & 0.23 & 0.42 & 0 & 1 \\ 489 & 0.17 & 0.37 & 0 & 1 \\ 489 & 0.28 & 0.45 & 0 & 1 \\ 489 & 0.28 & 0.45 & 0 & 1 \\ & & & & \\ 489 & 0.50 & 0.13 & 0.053 & 0.67 \\ 489 & 0.51 & 0.13 & 0.065 & 0.66 \\ 489 & 5.73 & 1.34 & 2.25 & 15.0 \\ 489 & 5.70 & 0.94 & 2.85 & 9.84\end{array}$

Note: The sample is restricted to the 489 English seats. 


\section{A8. Estimating newspaper circulation}

To obtain newspaper circulation numbers, we rely on information from two returns to the House of Commons in 1833 regarding the stamp duties paid by each newspaper published in London and in the English provinces (House of Commons, 1833a, 1833b). Each (newspaper) page published required a stamp so that these figures can be converted into an estimate of the newspapers' circulation. We follow Wadsworth (1955) and use the following conversion factors: for weekly newspapers, 50000 stamps per year correspond to 1000 copies sold by weekly newspapers each week; 3.2 million stamps per year correspond to 10000 copies sold by daily newspapers each day. We convert the thrice and twice dailies into dailies and use the conversion factor for the dailies to estimate the number of copies per day. The weekly circulation numbers are converted into yearly figures by assuming 52 weeks per year and the daily circulation numbers are converted into yearly numbers by assuming 52 six-day weeks. Outside London, all 130 local or regional newspapers were weeklies; in London there were 12 dailies (with The Times being by far the largest), seven newspapers published three times a week, one twice a week and 37 weeklies. To make London comparable to the provinces, we estimate circulation numbers as the total number of papers published in a year. 


\section{A9. Historical Evidence}

The results of the statistical analysis support the Political Expedience and Public Opinion Hypotheses while the Threat of Revolution Hypothesis receives less of a strong support. As a complement to this, we consider, in this section, historical evidence on the importance of threat of revolution, reform related agitation, lobbying and mass-mobilization, and political expedience as perceived by the participants themselves and contemporaneous observers. For this purpose, we draw on the transcripts of the debates in the House of Commons and the House of Lords, Newspaper reports and private letters, along with secondary sources.

\section{A9.1. The threat of revolution}

The Whig school of Victorian historians (e.g., McCarthy 1852; Trevelyan, 1920) emphasize that in 1830-1832, Britain was on the brink of a revolution that was only avoided by the timely concessions made by the ruling oligarchy (Trevelyan 1937, pp. 635-36). Historians of the British working class, such as Cole (1927), Cole and Postgate (1961) and Thompson (1963), also emphasize revolutionary threats and the possibility of an alliance between urban workers and the middle class as the cause of the reform. It is certainly true that many of the elements of a revolution were present in the early 1830s: a major rural uprising (the Swing riots), an emerging urban working class, a disgruntled middle class unhappy with the unreformed political system, vocal Radical leaders, a network of political unions that could mobilize thousands of reform supporters to their meetings, and the newspapers reported with direct reference to the July revolution in France that tricolor flags were paraded at demonstrations in London. It is also true that there were rumors of an uprising if the bill failed; and the fact that the authorities hastily filled the Tower of London's moat with water to forestall an attack and ringed London with 7000 troops and stationed 2000 New Police in Westminster in the autumn of 1830 suggests that the threat was considered real (Tilly, 1995, pp. 287-88). In 
a private letter to the MP Joseph Hume, Chartist leader Francis Place warned that "there must be a radical change, not a sham reform ..... if all concessions be refused, the people will become outraged and no one can tell what may follow." It is also clear from the transcripts of the seven days of debate that preceded the roll call vote on 22 March 1831 that many MPs saw the reform as a necessary means to avoid a revolution. John Russell who had presented the bill on March $1^{\text {st }}, 1831$, had the opportunity to make the last substantive remarks on 22 March 1831 . He used the example of the revolution in France in July 1830 to suggest that it could have been prevented by concessions to the people and that reform in Britain was now required to avoid a revolution. Similar views were expressed in the debate in the House of Lords in November 1830 when Prime Minister Charles Grey first announced that he intended to seek reform. The Earl of Radnor said "that Parliamentary Reform was not merely expedient, but the only measure which could ensure the salvation of the country" (Hansard HL Deb 22 November 1830, vol. 1, c604); a view also expressed by Grey himself in his speech to the House of Lords. This suggests the possibility that some MP were, in fact, influenced by fear of a revolution or at least were willing to use the threat of a revolution as an argument in the debate.

\section{A9.2. Public Opinion}

The many meetings and demonstrations organized by reform supporters around the country in 1830-31 were brought to the attention of the MPs and other members of the reading public through reports in local and national newspapers. For example, on 8 March 1831, one could read in the Times and in the Manchester Guardian that a meeting in Manchester gathered 3,000 participants in support of the reform bill. It is clear from the debate in the House of Commons that such meetings made an impression on the MPs and "public support" was used as one argument for the reform. The Whig MP Thomas Denman, for example, appealed to "a great meeting in the county of Nottingham where almost every respectable gentleman attended and where the resolution had been unanimously in favor of the measure [reform]" in his defense 
of the reform on 22 March 1831 (Hansard HC Deb 22 March 1831, vol. 3, c719). Likewise, the Tory MP Robert Palmer voted in favor of the reform in deference to his Berkshire constituents' strong support for the bill. He admitted in his contribution to the debates that his own had been the only dissentient voice at a meeting in his constituency and he reiterated that the bill went further than he could personally endorse (Fisher 2009). Of course, not all MPs were convinced by such agitation, but it is clear that the MPs were aware of it and sometimes participated in reform meetings themselves. Petitions also came to the attention of the MPs and of the Lords, and they were frequently mentioned both by supporters and opponents of reform. Many opponents, seeing themselves as "trustees" rather than as "delegates" (see below in subsection A9.3), went to great length explaining why they would vote against the bill despite the wishes of their voters. Tilly (1995, p. 239) describes this process of agitation as the "parliamentarization of contention". Taken together, this suggests that the MPs might have been influenced by agitation, petitions and by mass mobilization in favor of reform in the areas where they were elected bolstering our interpretation of the statistical results.

\section{A9.3. Political expedience}

Many MPs viewed themselves as "trustees" rather than as "delegates" representing the interest of their constituents (Schonhardt-Bailey 2006, Ch. 1). The view of a MP as a "trustee" was held particularly strongly by many Tory MPs who saw it as their role to act as they deemed to be in the national or wider public interest and to follow their ideological pre-disposition rather than the demands of their constituents or broader special interests. ${ }^{35}$ The support for a

\footnotetext{
${ }^{35}$ It should be made clear that the MP as a "trustee" was not an invention of Tories in the last years of the Unreformed Parliament to defend the political status quo. Edmund Burke, a leading Whig intellectual, had written in 1770 that "[i]t is the business of the speculative philosopher to mark the proper ends of Government. It is the business of the politician, who is the philosopher in action, to find out proper means towards those ends, and to employ them with effect" (Burke, 1770). Acting in accordance with his views, Burke neglected the interests of
} 
limited, property based suffrage and redistribution of seats from the "rotten" boroughs to the industrial towns and cities amongst the Whig elite reflected a belief that this was a necessary condition for a stable society that they would naturally govern (Mitchell 2005). The Tory opposition was based on the idea of the "territorial constitution" which centers on landownership and which gives owners of real property the right to govern, not only to protect their fixed assets, but also to ensure as trustees that all interests of society are considered (Gash 1951). One example of this is the defense of the unreformed system that Philip Henry Stanhope, Viscount Mahon, who represented the "rotten" borough of Wootton Basset, articulated during the debate in the House of Commons on 22 March 1831. He stressed how the nomination constituencies of Gatton and Old Sarum served the useful purpose of counterpoising the effect of more popular representation elsewhere and thus ensured the "blending of several interests in forming a perfect whole" (Hansard HC Deb 22 March 1831, vol. 3, c719). However, in the same way that the Whig support for reform can be seen as an attempt to gain party political advantage, there was clearly a personal motive underlying such a principled stance against reform: the prospective loss of a seat. The fact that many other speakers in the debate went to great length to stress their role as trustees and that they opposed the reform bill out of principle and not because they would personally be affected suggests that, at the very least, there was a suspicion that personal expedience played a role in the way the MPs voted.

the voters who had returned him in the contested constituency of Bristol in 1774 and was defeated in the following election in 1780. 


\section{A10. Definitions and sources}

\section{Support for parliamentary reform}

Yes vote (Second Reading of Great Reform Act) is a dummy variable equal to one if a MP, who took part in the second reading of the Great Reform Act on 22 March 1831, voted in favour of the reform bill and equal to zero otherwise. Source: Hansard (1831, vol. 2, pp. 719-826).

Present is a dummy variable equal to one if the MP was present in the House of Commons on March 221831 for the vote and zero if not. Source: Hansard (1831, vol. 2, pp. 719-826).

Yes vote, 1810 is a dummy variable equal to one if a MP, who took part in the vote on the reform bill put forward by Thomas Brand on 21 May 1810 (1807 Parliament), voted in favour of the bill and equal to zero otherwise. Source: Hansard, House of Commons (1810, vol. 15).

Yes vote, 1822 is a dummy variable equal to one if a MP, who took part in the vote of on the reform bill put forward by Lord John Russell on 25 April 1822 (1820 Parliament), voted in favour of the reform bill and equal to zero otherwise. Source: Hansard, House of Commons (1822, vol. 7).

\section{Members of Parliament}

Whig/Radical YEAR with YEAR $\in 1810,1822$, and 1830 is a dummy variable equal to one if a MP belonged to the Whig or Radical faction in Parliament and zero otherwise in the relevant year. It is not a straightforward task to determine the political affiliation of the MPs. The Tory and Whig groups were relatively loose organizations and some MPs changed their allegiance over their political careers. To construct a complete record of the political affiliations of all the English MPs elected in 1830, we started with the information given in Hansard (1831, vol. 2, pp. 719-826) and evaluated and compared the bibliographical information provided by Dod and Dod (1832), Namier and Brooke (1964), Stooks Smith (1973), Thorne (1986), and Fisher (2009). Disagreement amongst the sources was, typically, due to the fact that a MP had changed affiliation over his career. In these cases, we resolved the disagreement by associating 
the MP with his party affiliation as of 1830 . For the MPs selected for the 1810 and 1822 parliament, we followed a similar procedure, except that the Hansard could not be used as a starting point because no party affiliation was reported in relation to the failed reform bills in 1810 and 1822. Source: Dod and Dod (1832), Namier and Brooke (1964), Stooks Smith (1973), Thorne (1986), and Fisher (2009).

Age of MP codes the age of each MP as of March 1831. Source: Dod and Dod (1832), Namier and Brooke (1964), Stooks Smith (1973), Thorne (1986), and Fisher (2009).

Army career is a dummy variable equal to one if a MP was a career soldier and zero otherwise. Source: Dod and Dod (1832), Namier and Brooke (1964), Stooks Smith (1973), Thorne (1986), and Fisher (2009).

Dynasty heir is a dummy variable equal to one if a MP was returned to a seat when coming of age and without any other occupation. Source: Dod and Dod (1832), Namier and Brooke (1964), Stooks Smith (1973), Thorne (1986), and Fisher (2009).

Financier is a dummy variable equal to one if a MP was a banker or working in the financial sector and zero otherwise. Source: Dod and Dod (1832), Namier and Brooke (1964), Stooks Smith (1973), Thorne (1986), and Fisher (2009).

Industrialist is a dummy variable equal to one if a MP was an industrialist and zero otherwise. Source: Dod and Dod (1832), Namier and Brooke (1964), Stooks Smith (1973), Thorne (1986), and Fisher (2009).

Jurist is a dummy variable equal to one if a MP was a lawyer or had a legal profession (e.g., being a judge) and zero otherwise. Source: Dod and Dod (1832), Namier and Brooke (1964), Stooks Smith (1973), Thorne (1986), and Fisher (2009).

Merchant is a dummy variable equal to one if a MP was a merchant and zero otherwise. Source: Dod and Dod (1832), Namier and Brooke (1964), Stooks Smith (1973), Thorne (1986), and Fisher (2009). 
Relative in parliament is a dummy variable equal to one if a MP had a relative in Parliament. Source: Dod and Dod (1832), Namier and Brooke (1964), Stooks Smith (1973), Thorne (1986), and Fisher (2009).

Education is a dummy variable equal to one if the MP attended secondary schooling and/or university. Source: Fisher (2009).

Grand tour is a dummy variable equal to one if the MP took a Grand Tour in Continental Europe in his early 20s. Source: Fisher (2009).

Years in Parliament is the number of years that a MP sat in Parliament (with or without interruptions) prior to 1831. Source: Dod and Dod (1832), Namier and Brooke (1964), Stooks Smith (1973), Thorne (1986), and Fisher (2009).

Landowner is a dummy variable equal to one if the MP was a significant landowner. Source: Dod and Dod (1832), Namier and Brooke (1964), Stooks Smith (1973), Thorne (1986), and Fisher (2009).

Whig share in YEAR with YEAR $\in 1826,1830$ is the percentage share of seats in a constituency won by either Whig or Radical candidates in YEAR election. Source: Thorne (1986) and Fisher (2009).

\section{Protest}

All protest is the estimated number of participants in all types of protest in England and Wales between 1 January 1828 and 22 March 1831, by county. Source Horn and Tilly (1988).

Violent unrest is the estimated number of participants in violent unrest in England and Wales between 1 January 1828 and 22 March 1831, by county. Source Horn and Tilly (1988).

Peaceful protest is the number of participants in peaceful protest in England and Wales between 1 January 1828 and 22 March 1831, by county. Source Horn and Tilly (1988). 
Rural violent is the estimated number of participants in rural violent unrest in England and Wales between 1 January 1828 and 22 March 1831, by county. Rural violent unrest is approximated by the Swing riots. Source Horn and Tilly (1988).

Urban violent is the estimated number of participants in urban violent unrest in England and Wales between 1 January 1828 and 22 March 1831, by county. Urban violent unrest is calculated as the difference between violent unrest and rural violent. Source Horn and Tilly (1988).

Meetings is the number of estimated participants in meetings and delegations in England and Wales between 1 January 1828 and 22 March 1831, by county. Source Horn and Tilly (1988).

Gatherings is the estimated number of participants in gatherings (unannounced meetings and demonstrations) in England and Wales between 1 January 1828 and 22 March 1831, by county. Source Horn and Tilly (1988).

Reform agitation is the estimated number of participants in reform related agitation (meetings and gatherings) in England and Wales between 1 January 1828 and 22 March 1831, by county. Source Horn and Tilly (1988).

All protest (\#event) is the number of all types of protest events in England and Wales between 1 January 1828 and 22 March 1831, by county. Source Horn and Tilly (1988).

Violent unrest (\#event) is the number violent unrest events in England and Wales between 1 January 1828 and 22 March 1831, by county. Source Horn and Tilly (1988).

Peaceful protest (\#event) is the number of peaceful protest events in England and Wales between 1 January 1828 and 22 March 1831, by county. Source Horn and Tilly (1988).

Rural violent (\#event) is the number of rural violent unrest events in England and Wales between 1 January 1828 and 22 March 1831, by county. Rural violent unrest is approximated by the Swing riots. Source Horn and Tilly (1988). 
Urban violent (\#event) is the number of urban violent unrest events in England and Wales between 1 January 1828 and 22 March 1831, by county. Urban violent unrest is calculated as the difference between violent unrest and rural violent. Source Horn and Tilly (1988).

Meetings (\#event) is the number of meetings and delegations in England and Wales between 1 January 1828 and 22 March 1831, by county. Source Horn and Tilly (1988).

Gatherings (\#event) is the number of gatherings (unannounced meetings and demonstrations) in England and Wales between 1 January 1828 and 22 March 1831, by county. Source Horn and Tilly (1988).

Reform agitation (\#event) is the number of reform related agitation (meetings and gatherings) events in England and Wales between 1 January 1828 and 22 March 1831, by county. Source Horn and Tilly (1988).

Petitions is the difference between the number of petitions for and against parliamentary reform received by the House of Commons between 1 January 1828 and 22 March 1831 originating from each constituency. The data were constructed by word searches for the name of each constituency in the list of petitions related to parliamentary reform. Source: Journal of the House of Commons (1828-1831, vol. 83-86).

\section{Expected consequences of reform}

Net seat gain reports the difference between the number of seats allocated to each county and to the borough constituencies located within its borders by the reform (based on the final seat allocation) and the number of seats in the Unreformed Parliament. Source: Philbin (1965).

Net seat gain proposal reports the difference between the number of seats allocated to each county and to the borough constituencies located within its borders by the reform (using the proposed seat allocation) and the number of seats in the Unreformed Parliament. This variable is used in Table A2. Source The statutes of the United Kingdom of Great Britain and Ireland (1832, pp. 154-206). 
Disenfranchised is a dummy variable equal to one if the constituency that a MP represented was scheduled in the bill to lose all seats and zero otherwise. Source: The statutes of the United Kingdom of Great Britain and Ireland (1832, pp. 154-206).

Patron controlled is a dummy variable equal to one if the constituency was under full or partial control of a local patron or by the Treasure or if no contested election had taken place since 1802, and zero otherwise. Source: Philbin (1965), Cannon (1973) and Fisher (2009).

Landed interest is a dummy variable equal to one if a MP was elected to a county seat and zero if he was elected to either a borough or to one of the university seats. Source: Dod and Dod (1832), Namier and Brooke (1964), Stooks Smith (1973), Thorne (1986), and Fisher (2009).

\section{Institutional controls}

Local newspapers is an estimate of the number of newspapers circulated in each county in 1831. See Appendix A8 for how this is calculated. Source: House of Commons (1833a, $1833 b)$.

University constituency is a dummy variable that is equal to one for the two university constituencies. The universities of Cambridge and Oxford had the right to return two MPs each. The electors were the graduates of the two universities. Source: Dod and Dod (1832), Namier and Brooke (1964), Stooks Smith (1973), Thorne (1986), and Fisher (2009).

Narrow franchise is a dummy variable that is equal to one for borough constituencies with either a burgage or a corporation franchise and to zero otherwise. Under the Unreformed Parliament there were six different types of parliamentary franchises in operation for the borough constituencies: scot and lot, potwalloper, freeman, freeholder, burgage, and corporation franchises. The burgage and corporation boroughs had very narrow franchises, which often limited the number of voters to less than 50. In the burgage boroughs, only the owners of a property with an old form of tenure, called the burgage, could vote. These were 
often limited to plots of land that had formed the borough when it was first laid out and could be owned by a single person. In the corporation boroughs, only members of the local town council, called the corporation, could vote. In other boroughs with scot and lot, potwalloper, or freeman franchises, the electorate tended to be more sizable but rarely included more than 1000 voters, except in the largest towns such as London, Westminster and Bristol. Source: Philbin (1965) and Brock (1973, Table 2).

Uncontested elections YEAR with YEAR 1810, 1822, is equal to one for a constituency if none of the eight previous elections excluding the current one was contested, and zero otherwise. Source: Cannon (1973, Appendix III).

\section{Demographic, economic and spatial controls}

Emp. Herfindahl index is the sum of the square of the share of individuals in each Census registration district working in agriculture, in trade as professionals and in other occupational categories. Each constituency is matched to the Census registration district that is the closest geographical unit and is coded for 1811, 1821 and 1831. Source: Census of Great Britain (1811, $1821,1831)$.

Population density is the number of inhabitants per inhabited house in the constituency and is coded for 1811, 1821 and 1831. Source: Census of Great Britain $(1811,1821,1831)$.

Top wealth is a dummy variable equal to one if the county belongs to the fourth and highest quartile of the county level wealth distribution. Source: Census of Great Britain (1831) "Population. Comparative account of the population of Great Britain in the years 1801, 1811, 1821 and 1831" pp. 348ff."

High wealth is a dummy variable equal to one if the county belongs to the third quartile of the county level wealth distribution. Census of Great Britain (1831) "Population. Comparative account of the population of Great Britain in the years 1801, 1811, 1821 and 1831 " pp. 348ff." 
Medium wealth is a dummy variable equal to one if the county belongs to the third quartile of the county level wealth distribution. Source: Census of Great Britain (1831) "Population. Comparative account of the population of Great Britain in the years 1801, 1811, 1821 and 1831” pp. 348ff."

Thriving economy is a dummy variable that is equal to one if Philbin (1965) singles out the constituency as being prosperous around 1830, and zero otherwise. Source: Philbin (1965).

Declining economy is a dummy variable that is equal to one if Philbin (1965) singles out the constituency as being in decline around 1830, and zero otherwise. Source: Philbin (1965).

Agriculture (emp. share) is the number of tenant farmers and large landowners employing agricultural laborers, tenant farmers not employing agricultural laborers, and agricultural laborers as a proportion of the workforce in each Census registration district. Each constituency is matched to the Census registration district that is the closest geographical unit. Source: Census of Great Britain, 1831.

Trade (emp. share) is the number of persons listed working in industry, trade or as artisans as a proportion of the workforce in each Census registration district. Each constituency is matched to the Census registration district that is the closest geographical unit. Source: Census of Great Britain, 1831.

Professionals (emp. share) is the number of professionals (lawyer, doctors, and so on) as a proportion of the workforce in each Census registration district. Each constituency is matched to the Census registration district that is the closest geographical unit. Source: Census of Great Britain, 1831

Distance to London (inverse) is the inverse of the travel time distance from each constituency to London measured in units of travel days (assuming that a person can travel 30 kilometers per day). Source: Aidt and Franck (2015). 


\section{Instrumental variable}

Population pressure 1811-31 is the average population growth rate between 1811 and 1831 in each county times population density in 1811. Source: Census of Great Britain 1811, 1821 and 1831. 
Figure A1: Gatherings and Meetings in English and Welsh counties by number of participants, 1 January 1828 - 22 March 1831.

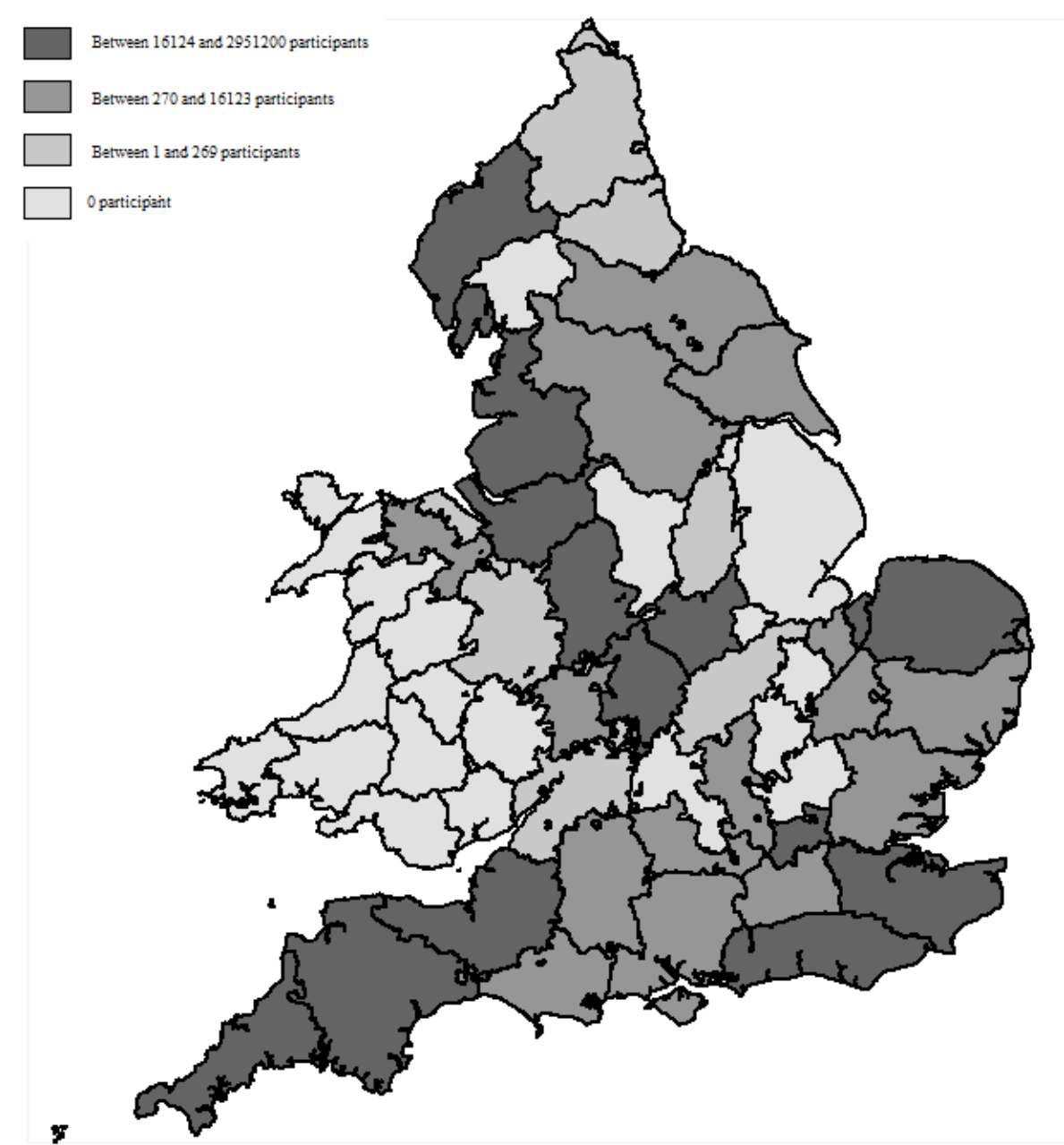

Figure A1a. Meetings

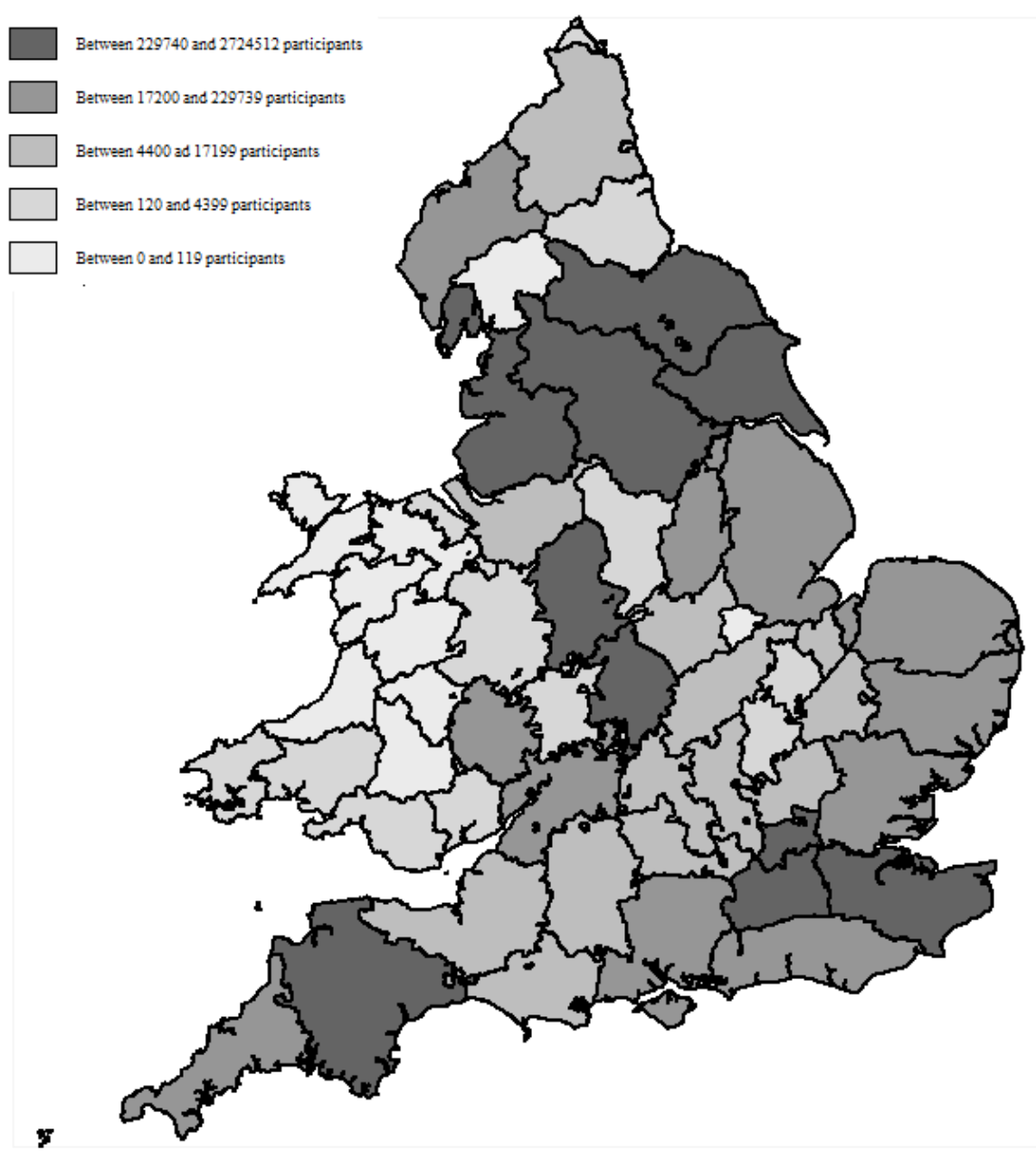

Figure A1b. Gatherings

Source: Horn and Tilly (1988). 


\section{Additional References (not listed in the main text)}

Burke, Edmund, 1770, Thoughts on the Cause of the Present Discontent, J. Dodsley in the PallMall, UK.

Cole, G.D.H., A Short History of the British Working Class Movement, 1789-1927. London, UK: George Allen \& Unwin, 1927.

Cole, G.D.H., and Raymond Postgate, The British Common People, 1746-1946. New York, NY: University Paperbacks, 1961.

Gash, Norman 1951. "Peel and the Party System, 1830-50." Transactions of the Royal Historical Society 1: 47-69.

Wadsworth A.P. 1955 "Newspaper circulations, 1800-1954," Transactions of the Manchester Statistical Society, 20, 1-41. 